Fekete Márta

A társadalmi fenntarthatóság és jól-lét a demenciával élők informális ápolói körében 
Döntéselmélet Tanszék

Témavezető:

Dr. Pataki György, PhD

(C) Fekete Márta 
Budapesti Corvinus Egyetem

Gazdálkodástani Doktori Iskola

\section{A társadalmi fenntarthatóság és jól-lét a demenciával élők informális ápolói körében}

doktori értekezés

Dr. Fekete Márta

Budapest, 2020. 


\section{Tartalomjegyzék}

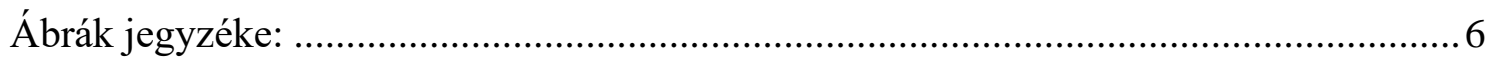

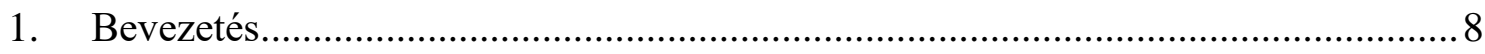

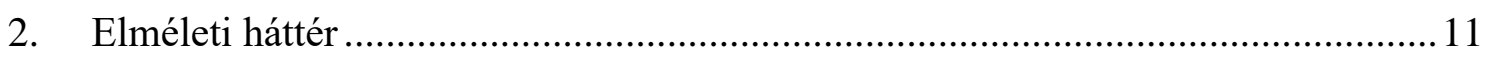

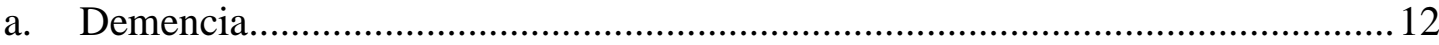

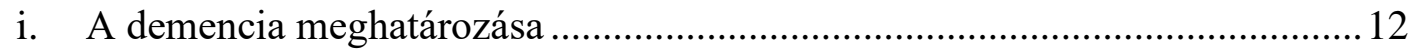

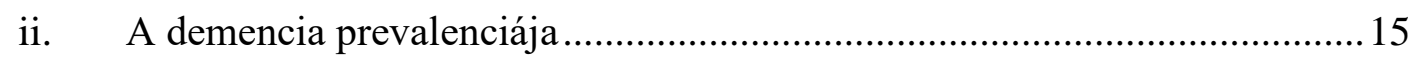

iii. A demencia mint gazdasági tényező........................................................... 17

iv. A demencia mint stratégiai tervezést igénylö társadalmi tényező ................. 18

b. Társadalmi fenntarthatóság ........................................................................... 19

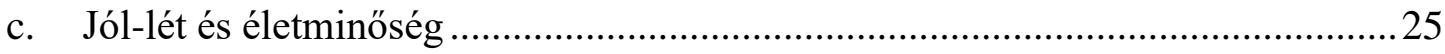

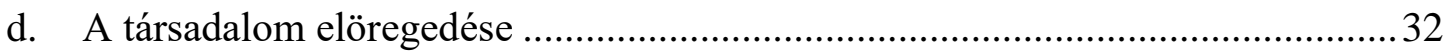

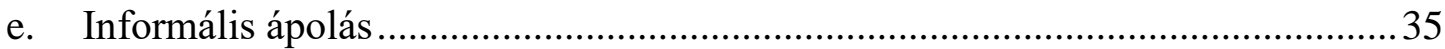

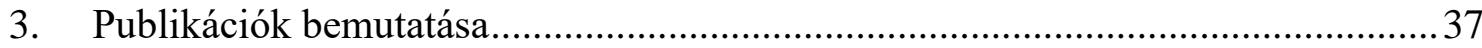

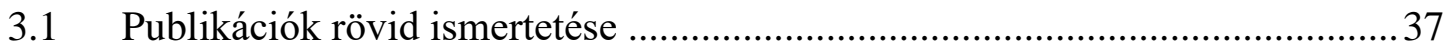

3.1.1. Rendszertérképezés alkalmazása a hazai demenciastratégia

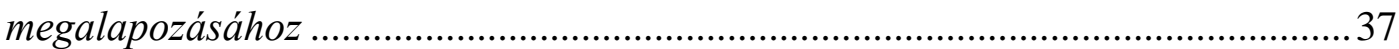

3.2. Older New Zealanders in caregiving roles: Psychological functioning of caregivers of people living with dementia ............................................................ 38

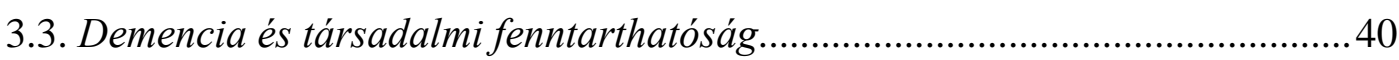

$3.2 \quad$ Publikációk teljes szövege.......................................................................... 41

3.2.1. Rendszertérképezés alkalmazása a hazai demenciastratégia megalapozásához

3.2.2 Older New Zealanders in caregiving roles: Psychological functioning of

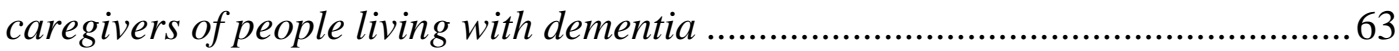

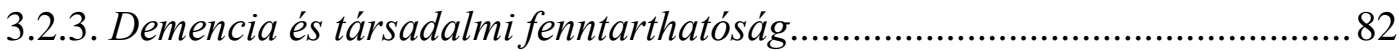

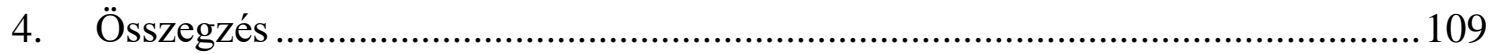

Melléklet I. - Civil tudomány és demencia ................................................................ 116

Melléklet II. - Gondozási rendszer típusa és életminőség összefüggése........................118

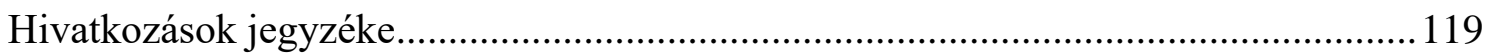

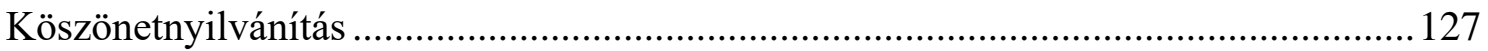




\section{Ábrák jegyzéke:}

1. ábra: Kutatási fókuszok és publikációk kapcsolata

2. ábra: A környezet - társadalom - gazdaság rendszerének viszonya

3. ábra: A jól-létet meghatározó tényezők-OECD jól-léti indikátorok

4. ábra: A Világ, Európa és Magyarország korfája 2019-ben

5. ábra. Magyarország lakosságának korcsoportonkénti alakulása 2016-2070

6. ábra: Demenciával élők életminőségét befolyásoló tényezők

7. ábra: Pearlin Alzheimer-betegek ápolóira vonatkozó stressz-modellje

8. ábra: A publikációk tanulságai, mint a szakpolitikai javaslatok forrásai 
Mottó:

„,Az emberek azért kezdenek kutatásba, mert van egy álmuk arról, hogy belátásaikkal és felismeréseikkel hozzátesznek valami fontosat a világhoz. Azonban nem elég csupán álmodozni, álmainkat meg is kell tudnunk valósítani."

/Juliet Corbin - Anselm Strauss, 2015 - A kvalitatív kutatás alapjai;

L'Harmattan - SE-EKK-SAGE, elsö magyar kiadás, 54.o./ 


\section{Bevezetés}

Doktori tanulmányaim 2014-ben történt megkezdésekor kutatási fókuszként az idősödést (ageing) jelöltem meg. Elképzelésem szerint az idősödés folyamatának társadalmi, gazdasági hatásaival, megoldások keresésével kívántam foglalkozni. Felmérve a téma gazdálkodástudományi területen is szerteágazó voltát, a kutatási fókuszt az időskorúak arányának növekedését szükségszerüen kísérő informális ápolási tevékenységre helyeztem. Az informális, családtagok és ismerősök által, önkéntesen nyújtott gondozási tevékenységnek számos kórállapot, kondíció esetén van egyre nagyobb szerepe, de ezek közül is kiemelkedő a demencia, amely nem ritkán évtizeden át tartó feladat elé állítja az ápolást vállalókat, egyéneket vagy családokat. A választásban szerepe volt orvosszakmai tapasztalatomnak, valamint azoknak a szakértői véleményeknek, amelyek szerint az orvostudományi, egészségtechnológiai és gyógyszeripari fejlesztések e tünetegyüttes tekintetében - sok más, krónikus, senyvesztő kórképpel szemben - nem fognak sem a közeli jövőben, sem néhány évtizedes távon kezelési vagy gondozási téren jelentős változást előidézni. A demencia, mint az időskori kiszolgáltatottság egyik vezető oka, mely mind tartamban, mind kiterjedtségben (támogatást igénylő tevékenységek számában, mértékében) az elsődleges tényezők között szerepel az időskorban jelentkező informális ápolási szükséglet hátterében, a várható élettartam kitolódásával egyre nagyobb előfordulással és tartósan elkíséri az emberiséget. A társadalmi fenntarthatóságot veszélyeztető időskori funkcióveszteségek közül a kognitív funkció hanyatlása jelenleg a legkevésbé sikeresen támogatható, ellensúlyozható, korrigálható képességcsökkenés.

A kutatói attitüdöm kialakulása, fejlődése során tudatosan választottam a bevonódást, a demenciával élőkkel, intézményi vagy otthoni gondozóikkal és családtagjaikkal való kapcsolat kialakítását. 2016 óta veszek részt a demenciával élőket és hozzátartozóikat segítő közösségek életében. A szemléletem formálásában vitathatatlan szerepe van mindannak az információnak, benyomásnak, tapasztalatnak, melyhez a közösség rendezvényein, kisebb vagy nagyobb csoportok összejövetelein jutottam, illetve annak az inspiráló közegnek, melyet az ezeken részt vevő gondozó családok, családtagok, demenciával élök, gondozó vagy az ellátás más területén részt vevő szakemberek, vagy akár a laikus érdeklődők, segíteni szándékozók teremtenek. A gazdagodást számomra 
nemcsak az ismeretbővülés biztosítja, hanem annak megélése is, hogy a tágabb társadalmi kontextus megvilágítása vagy az egyéni problémák meghallgatása útján is hozzájárulhatok a „nem vagy egyedül” érzés kialakításához, mely a társadalmi fenntarthatóság megoldásai közül a közösségi megközelítés jó gyakorlati példája.

A demencia társadalmi és gazdasági jelentőségét számos ország már azelőtt felismerte, hogy az Egészségügyi Világszervezet (World Health Organization, WHO) azt az úgynevezett ,„prioritást élvező kórképek” közé sorolta 2008-ban (WHO, 2008). Erről tanúskodnak azok a nemzeti akciótervek, melyek 2001-től már megjelentek (például az Alzheimer Europe ernyőszervezet honlapján követhetők nyomon) ${ }^{1}$, és mintául szolgálnak a feladattal még lemaradóknak. Magyarország annak ellenére nem rendelkezik demenciastratégiával, hogy mind a demográfiai folyamatok, mind a populációt jellemző betegségösszetétel - szív-érrendszeri betegségek, agyi érkatasztrófák magas előfordulási gyakorisága - miatt a demenciával élők számának folyamatos, jelentős mértékü emelkedése várható. A betegpopuláció méretének említésekor azonnal le kell szögezni, hogy ma nem rendelkezünk hiteles információval a Magyarországon demenciával élők számáról. Talán ezzel is magyarázható, hogy eddig nem irányult kellő figyelem a hazai szakpolitika részéről a kórképre. Az eddig fel nem ismert esetek sejthetően nagy száma ugyanakkor azt is jelenti, hogy amennyiben sikeresen megvalósulnának egy akcióterv kezdeti lépései - melyek jellemzően a kórkép bemutatása, a figyelemfelhívás, az érintettek „megtalálása”, azaz a szürés -, akkor tömegek jelennének meg ellátási igénnyel. Az egészségügyi és a szociális ellátórendszer kapacitáshiánya miatt a családokra rövid távon igen nagy terhek hárulhatnak, melyek feloldására, enyhítésére készülni lehet megalapozott szakpolitikai döntésekkel, melyek a demencia esetén interdiszciplináris együttmüködést tesznek szükségessé.

A disszertáció alapját képező publikációkat is ez a vezérfonal, a releváns szakpolitikai döntésekhez szükséges információk összegyüjtésének módja és szerepe füzi egybe (1. ábra). Kutatási fókuszom nem kizárólag az informális ápolási tevékenység negatív következményeinek elhárítására helyeződik. Kiemelt figyelmet fordítottam a tevékenység pozitív hozadékaira, bízva abban, hogy a gondozó hozzátartozók számára biztosítható rendszerszintű támogatás e tényezők bemutatásával, tudatosításával is hozzájárul az informális ápolók jól-létének növekedéséhez.

\footnotetext{
${ }^{1}$ https://www.alzheimer-europe.org/Policy-in-Practice2/National-Dementia-Strategies (2019.02.23.)
} 
1. ábra: Kutatási fókuszok és publikációk kapcsolata

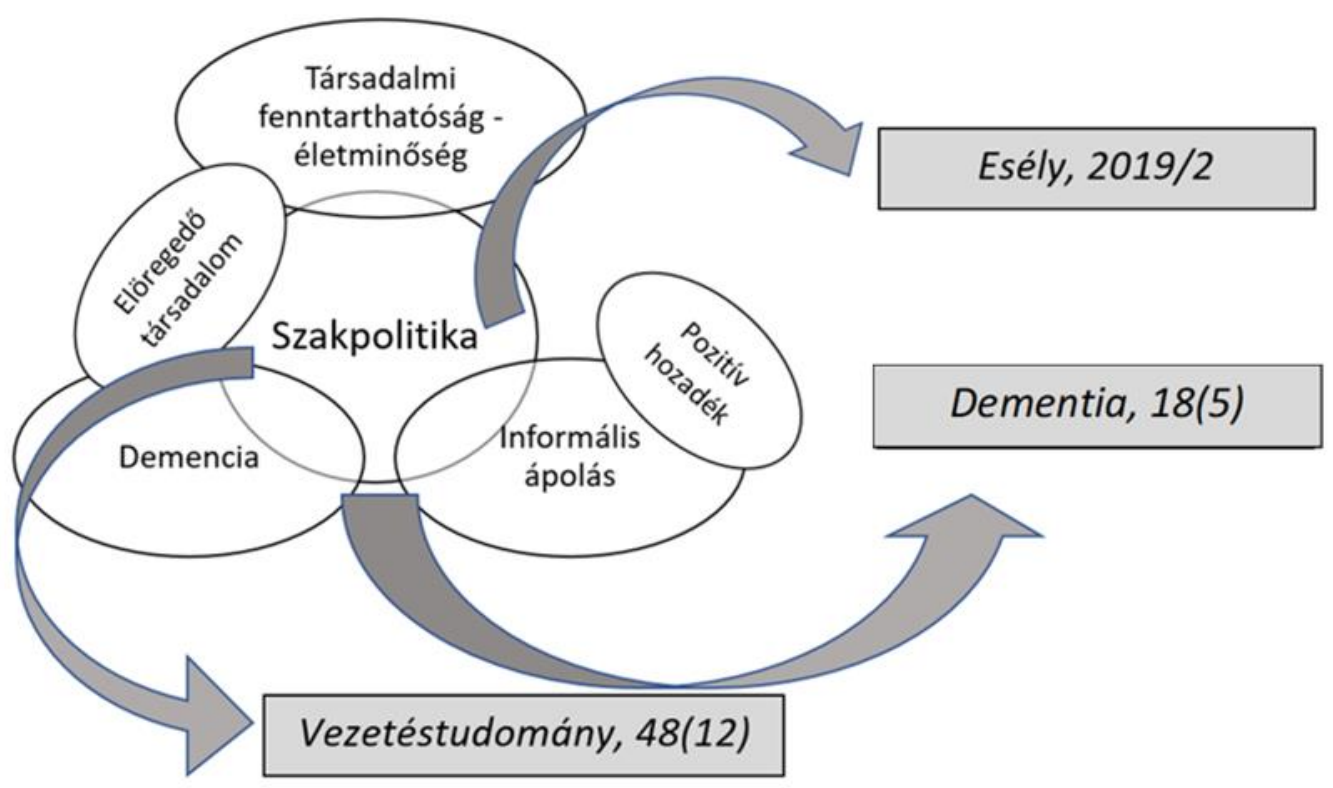

A Vezetéstudomány XLVIII. évfolyamának 12. számában Rendszertérképezés alkalmazása a hazai demenciastratégia megalapozásához címmel megjelent egyszerzős publikációm egy módszertani kísérletet mutat be (Fekete, 2017). Az elsőszerzős, angolnyelvű publikációm egy három hónapos, saját szervezésủ új-zélandi tanulmányút gyümölcse, mely a demenciával élő családtagokat ápolók életminőségét befolyásoló tényezőket tárja fel Older New Zealanders in caregiving roles: Psychological functioning of caregivers of people living with dementia címmel (Fekete et al., 2019a). Mindkét publikációt a kutatóvá fejlődésem fontos mérföldkövének tekintem, nemcsak a publikációk közlésre történő elfogadásának puszta, de igen felemelö ténye miatt, hanem azért is, mert mindkettőt fontos visszajelzésként éltem meg. A Vezetéstudomány címü folyóirat kvalitatív fókuszú különszámában történő megjelenés további ösztönzést jelentett abba az irányba, hogy a kvalitatív kutatási módszertan alkalmazása a „learningby-doing” nehézsége mellett megéri a fáradságot. Az új-zélandi adatbázis teljesen egyéni szempontú, saját indíttatású feldolgozása egyrészt megadta a kutatói szabadság, a kutatásban rejlö végtelen lehetőségek élményét, másrészt a kapott eredmények azonnal további kutatási ötleteket, lehetőségeket vetettek fel. 
Harmadik témába illeszkedő publikációm az Esély című társadalom- és szakpolitikai folyóiratban megjelent Demencia és társadalmi fenntarthatóság címü tanulmány (Fekete, 2019b). Ebben összegzést adok arról, hogy a demencia milyen gazdasági és társadalmi hatások révén releváns problémája a társadalmi fenntarthatóságnak, és nemzetközi példákon keresztül rávilágítok arra, hogy a betegek, valamint az ellátásukban fontos szerepet játszó családok jól-létének biztosításához milyen összehangolt szakpolitikai lépések tehetők.

A disszertáció elméleti hátteret ismertető részében a demencia, a társadalmi fenntarthatóság, a jól-lét és életminőség, a társadalom elöregedése és az informális ápolás fogalmak bemutatására kerül sor. A gyakorlati megközelítésemet erösen meghatározza az önkéntes közösségi tevékenységem, amely egyre határozottabb befolyást gyakorolt az elméleti kutatói fókuszomra is. Jövőbeli kutatási terveimben a célkitüzés központi eleme a társadalmi fenntarthatóság kérdése, a civil tudomány (citizen science) (Szabó, 2013) és az interdiszciplinaritás megvalósítása, kiemelten az egészségtudomány és a társadalomtudományi területek közti együttmüködés, kommunikáció elősegítése.

\section{Elméleti háttér}

Az elméleti háttér öt téma köré csoportosítva kerül bemutatásra. Az első fejezet témája a demencia, mivel a disszertáció alapját képező publikációkban kevesebb szó esik a tünetegyüttesnek az ismertetéséről, ugyanakkor az azzal kapcsolatos számos társadalmi és gazdasági aspektus értelmezéséhez fontosnak tartottam az ismeretek összegzését.

A doktori képzési specializáció szempontjából leginkább releváns társadalmi fenntarthatóság témáját a Semmelweis Egyetem Egészségtudományi Kara által 2018-ban kiadott Családtudományi jegyzetben (Fekete, 2018) megjelent Fenntartható társadalom című könyvfejezetem is tárgyalja. A fejezet megírására való felkérést megtisztelőnek, a tudományterületek közötti együttmüködés megvalósításában pedig fontos lépésnek könyveltem el. Disszertációmban a fogalom kialakulásának és értelmezésének 
aktualitásait emelem ki. Az ehhez szorosan kapcsolódó társadalom elöregedése témakörnél szintén támaszkodom a jegyzetben leírtakra. Az életminőség és szubjektív jóllét témakörök tárgyalása során kiemelten foglalkozom a fogalmak fejlődésével, interdiszciplináris megközelítésével és a közgazdasági hasznosítás kérdésével.

Az informális ápolás fogalma szintén kulcseleme az eddigi kutatói tevékenységemnek, és bár mindhárom publikáció tartalmaz ezzel kapcsolatos alapvető információkat, az elméleti hátteret ismertető fejezetben is röviden összegzem ezeket.

\section{a. Demencia}

i. A demencia meghatározása

A demencia nem egy betegséget jelöl, hanem egy tünetegyüttest illet az elnevezés. A demencia több kórképet kísérhet, különböző típusai vannak, melyek hátterében eltérö kórfolyamatok állnak. A mentális rendellenességek nemzetközileg elfogadott és alkalmazott rendszerezése az ezen a néven 1921 óta müködő Amerikai Pszichiátriai Társaság (American Psychiatric Association) nevéhez füződik. A társaság által összeállított Diagnostic and Statistical Manual of Mental Disorders (DSM - magyarul is ez a használt rövidítés) első alkalommal 1952-ben került kiadásra ${ }^{2}$. A mentális zavarok klasszifikációjának története egy rövid kitekintésre amiatt érdemes, mert részben magyarázatot ad a tünetegyütteshez való időnként visszás orvos-szakmai hozzáállásra, mely erős hatással volt és van mind a mai napig a demencia társadalmi megítélésére.

A DSM része a betegségek nemzetközi osztályozási rendszerének (International Classification of Diseases - ICD; magyarul Betegségek Nemzetközi Osztályozása, azaz BNO), mely a mindennapi gyakorlatban, például recepten a javallat, a gyógyszer elrendelését indokló betegség, vagy bármely orvosi dokumentáción a megállapított diagnózis rögzítésére használt kódolási rendszer. Az ICD elődje egy a halálokokat statisztikai céllal összegyüjtő lista volt (International List of Causes of Death), mely 1948-ban, az Egészségügyi Világszervezet (World Health Organization - WHO)

\footnotetext{
${ }^{2}$ Elérhetö: https://www.psychiatry.org/psychiatrists/practice/dsm/history-of-the-dsm (Letöltve:
} 2019.08.07.) 
létrejöttével egyidejüleg, annak égisze alatt bővült ki a betegségeket is magába foglaló osztályozási rendszerré, és került kiadásra az ICD-6, mint első verzió. A betegségosztályozó rendszernek jelenleg a 10-es számú, 1990-ben kiadott verzióját használja a világ több mint 100 országa 43 nyelvre lefordítva, és szolgálja az egészségügyi és statisztikai rendszereket például Magyarországon is ${ }^{3}$. A kódrendszer 11es számú verzióját 2018 júniusában, az előző verzió után 18 évvel bocsátották ki ${ }^{4}$. Ennek a lépésnek a jelentőségét jól szemlélteti, hogy ez a verzió nevesíti először a „játékszenvedélyt”, azaz ez az a pont, amikortól ez a betegség „statisztikai szempontból létezik”, azaz rá vonatkozó adatokat lehet gyüjteni szerte a világon.

A DSM integrálására a Betegségek Nemzetközi Osztályozása (BNO) rendszerébe 1952ben került sor először. A DSM volt az első klinikai szemléletü útmutató a mentális kórképek tekintetében. Az osztályozási rendszer későbbi fejlődését a pontos diagnosztikai kritériumok megfogalmazása jelentette, ezzel együtt az okok, mint kategóriaképző szempontok, háttérbe szorultak. Ebben a tekintetben a DSM a BNO rendszerénél sokkal komplexebb, tartalmasabb, mivel utóbbinak nem célja egy-egy betegség pontos fogalmának megadása. A BNO és a DSM rendszer tehát folyamatosan fejlődik, de mivel a megújulásuk nem teljesen összehangolt, így időszakosan - például jelenleg is - a betegségkódolás általános rendszere nem követi a pszichiátriai szakmai közmegegyezést a betegségek, állapotok osztályozását illetően, ami dokumentációs diszharmóniához, következményesen adatgyüjtési és elemzési nehézségekhez vezet.

A DSM első publikálását megelőzően is nyoma volt már egyébként az Egyesült Államokban a pszichés zavarok osztályozásának, és ezen alapuló célzott adatgyüjtésnek. Az első klasszifikáció pusztán adminisztratív célokat szolgált, és a mentális betegséggel érintettek számát kívánták felmérni a népszámlálások kapcsán. Az 1880-as népszámlálás során hét mentális betegséget különítettek el, és a demencia mellett olyan további hat kórképet említenek, melyeket mára nagyrészt szintén más elnevezéssel illet a szakmai osztályozó rendszer.

A DSM 2013-ban megjelent 5. verziójának kiadása nagy jelentőségü a demencia szempontjából (Nemeroff et al., 2013). A demenciát egy új entitás, a „neurokognitív

\footnotetext{
${ }^{3}$ Elérhetö: http://www.who.int/classifications/icd/en/ (Letöltve: 2019.08.07.)

${ }^{4}$ Elérhető: https://icd.who.int/en/ (Letöltve: 2019.08.07.)
} 
rendellenesség" (neurocognitive disorder) kategória alá sorolja be az új osztályozási rendszer, azon belül is a „súlyos neurokognitív rendellenesség” (major neurocognitive disorder) csoportba. Ugyanakkor a különböző eredetű formáknak az azonosításánál a demencia megnevezés továbbra is megmaradt (pl. Alzheimer demencia, Parkinson demencia, Lewy-testes demencia). Újdonságként az osztályozási rendszerben megjelenik az eddig demenciaként tárgyalt tünetegyüttes kevésbé súlyos formája, az „enyhe neurokognitív rendellenesség" (mild neurocognitive disorder) fogalma. Ennek a fogalomnak a megalkotása igen nagy jelentőségü, mivel kifejezi azt, hogy a demencia nem egy hirtelen kezdetü állapot, hanem annak létezik egy tulajdonképpeni előszobája, ahol az érintett akár igen hosszú időt is el tud tölteni anélkül, hogy a kóros kognitív működés felismerésre kerülne. A klinikai és kutatási területen már jóval a DSM 5. verziójának kiadása előtt alkalmaztak elnevezéseket a kognitív funkció enyhe fokú zavarára, melyek közül a legelterjedtebb a mild cognitive impairment (MCI) megjelölés volt (Petersen et al., 1999; Petersen, 2004.; Hugo és Ganguli, 2014.), melyet a magyar szakirodalom általában „enyhe kognitív zavar”-ként határoz meg (Volosin et al., 2013; Penke et al., 2016). Ez az új - az osztályozási rendszerbe való bejutást újonnan kivívó definíció azt fejezi ki, hogy az állapottal élő személynél a funkciócsökkenés még enyhébb mértékü, de az már „kompenzációs stratégiák”, ,alkalmazkodási trükkök” kidolgozását teszi szükségessé annak érdekében, hogy az érintett személy megőrizhesse függetlenségét, fenntarthassa mindennapi aktivitását (Sachs-Ericsson és Blazer, 2013).

Tekintettel arra, hogy a demencia, tehát a súlyos kognitív zavar jelenleg nem gyógyítható állapot, így napjainkban az enyhe stádium felismerése lenne az egyik legfontosabb feladat klinikai és társadalmi szempontból egyaránt. Az enyhe kognitív zavarral élőknél ugyanis a jelenleg alkalmazható gyógyszeres terápiáktól legalább az állapot stagnálásának elérése, vagy a progresszió lassítása remélhető, így végeredményben a súlyos állapot bekövetkezésének időbeli kitolása várható. Bár a határvonal az enyhe és a súlyos zavar között pontosan nehezen definiálható - ez is összecseng a relatív és abszolút deprimált helyzet megállapításával -, ugyanakkor rendkívül nagy a jelentősége a két csoport elkülönítésének, mivel ellátási igény tekintetében azok nagyon különböznek. Míg az enyhébb zavar stádiumában a háttérben álló ok feltárása, a célzott terápia mielőbbi

\footnotetext{
${ }^{5}$ neurokognitív - magyarul is gyakran ez a megjelölés használatos, mivel a kognitív szó nehezen fordítható le, csak összetett mondattal magyarázható, a gondolkodási funkció összetett zavarát jelöli.
} 
elindítása, és gondozási szempontból a jövőt illető döntésekre való felkészülés van a fókuszban, addig súlyos zavar fennállása esetén az aktív kezelés másodlagos jelentőségü, ugyanakkor a gondozási, támogatási igény felmérése - mind az érintett, mind az öt körülvevő család tekintetében - elsődleges szerepet kap. Itt is tettenérhető, hogy végeredményben az egyéni tulajdonságok, körülmények relatívvá teszik az orvosszakmailag abszolúttá alakítani próbált fogalmat, tünetegyüttest.

Ahogy Hugo és Gangulin (2014, 421.o.) fogalmaz: „A demencia diagnosztizálására többnyire akkor kerül sor, amikor a kialakult kognitiv elégtelenség elég súlyos mértéküvé válik ahhoz, hogy az érintse a társadalmi és/vagy munkavállalási képességet. Az enyhe kognitiv zavar egy köztes állapotot jelent a normál kognitív funkció és a demencia között, lényegében megtartott funkcionális képességekkel." 6

A mentális betegségek osztályozási rendszere a demencia etiológiája - a háttérben húzódó ok - tekintetében érdemben nem változott, és eredettől függetlenül súlyos vagy enyhe besorolást kaphat a kognitív zavarral érintett személy. Az eltérés hátterének megállapítása különösen fontos azonban az enyhe stádiumú betegek esetén, mert bár az esetek jelentős részében a folyamat nem visszafordítható, de egy kisebb csoportnál az állapot javulása is elérhető a kezelés időben történő megkezdésével. A leggyakoribb kiváltó ok az Alzheimer-kór, mely az esetek 60-70\%-áért felelős, nem gyógyítható (WHO, 2018). Megjelenhet ugyanakkor a demencia más neurodegeneratív ${ }^{7}$ kórfolyamatok kísérőtüneteként (például Parkinson-kórban), valamint további speciális formái is ismertek (Lewy-testes demencia, frontotemporalis demencia), melyek a kialakulás mechanizmusában, vagy akár a speciális agyterületi érintettség miatt a jellemző tünetekben jelent variánst.

\section{ii. A demencia prevalenciája}

A demencia prevalenciájával, előfordulásával kapcsolatban csupán becsült adatok ismertek, pontosnak vélt információk birtokában sem lehetünk biztosak abban, hogy

\footnotetext{
${ }^{6}$ Hugo és Ganguli, 2014:421: „Dementia is typically diagnosed when acquired cognitive impairment has become severe enough to compromise social and/or occupational functioning. Mild cognitive impairment (MCI) is a state intermediate between normal cognition and dementia, with essentially preserved functional abilities."

${ }^{7}$ neurodegeneratív - az idegrendszer, az idegsejtek károsodásával járó folyamat
} 
valós képet kapunk a tünetegyüttes előfordulásáról (Perera et al., 2018.; Prince et al., 2013). Egyrészt az előző szakaszban részletezett definiálási és besorolási körülmények, másrészt az adott ország egészségügyi adatrögzítési fegyelme, egységessége is erősen befolyásolja az elérhető adatok minőségét. Elgondolkodtató, hogy Magyarországra vonatkozó, közvetlen hazai forrású adat nem ismert. Fontos, tudományosan megalapozott hátteret ad a kognitív zavarral élők számának becslésére Prince és munkacsoportjának 2013-ban publikált kutatása (Prince et al., 2013), melyben három évtized irodalmát összegezték szisztematikusan, és végeztek metaanalízist. A kutatás forrásául szolgált a WHO és az ADI által közösen jegyzett „Dementia: a public health priority” (Wortmann, 2012) címet viselő műnek is; tulajdonképpen e két szervezet megbízása iniciálta az összegző kutatást, melynek adatait, előrejelzéseit gyakran idézik. A cikk alapos összegző munkája ellenére az eredmények korlátait jól mutatja, hogy a nemzetközi szervezet által definiált régiók (Global Burden of Disease - GBD régiók) eltérő mennyiségü adattal jellemezhetők. Így például a Közép-Európai Régióra vonatkozó adatok összesen 4, míg a Kelet-Európai Régióra vonatkozóan csupán egyetlen cikk szolgált adatforrásul. Az összegzésnek szintén gyengesége, hogy a legtöbb publikáció az 1990-es években született. Különösen igaz ez a magas jövedelmű országok adatait ismertető forrásokra, míg az alacsony-közepes jövedelmü országokra vonatkozóan szintén a 90-es évekből származik a legtöbb cikk, de esetükben legalább élénkebb aktivitás észlelhető az új évezredben. Ez a publikációs dinamika úgyis értelmezhető, miszerint a fejlettebb országokban hamarabb ismerték fel a probléma súlyát, és kezdtek el ezzel a kérdéssel tudományos szinten is foglalkozni, míg a fejletlenebb országokban az ingerküszöböt később érte el a demencia növekvő jelentősége. A Közép- és Kelet-Európát illető adathiány Magyarországra is vonatkozik. A demográfiai és epidemiológiai jellemzőkön alapuló régiós besorolása szerint hazánk az Európai Régió $\mathrm{C}$, szintén alkalmazott nomenklatúra szerint kelet-európai csoportjának tagja ${ }^{8}$, olyan társakkal, mint Fehéroroszország, Észtország, Kazahsztán, Lettország, Litvánia, Moldáv Köztársaság, Oroszország és Ukrajna, mely országokat alacsony csecsemőhalálozás és magas felnőtthalálozás jellemez. Európa országainak többsége, köztük a szomszédaink, Románia és Szlovákia kivételével, az 'A' besorolást kapták (nyugat-európai országokként is említve e kört), melyet nagyon alacsony csecsemő- és felnőtthalálozás jellemez. A köztes 'B' csoportba tartozó (közép-európai) országokat alacsony csecsemő- és

\footnotetext{
${ }^{8}$ Forrás: http://www.who.int/choice/demography/euro_region/en// (Letöltve: 2018.06.01)
} 
felnőtthalálozás jellemzi. Hazánk tehát az európai országok között a legrosszabb demográfiai besorolást kapta.

A szisztematikus irodalomkutatás során 2017 publikáció került a szerzők látókörébe, melyből végül 135 felelt meg minden kritériumnak, így ezek adatainak összegzésére került sor. A beválasztásra került publikációk minőségének értékelésekor megjegyzik, hogy a cikkek által ismertetett kutatások mindössze 43\%-ánál került sor a demencia multidimenzionális diagnosztizálására, mely során nem csupán a kognitív / gondolkodási funkció hanyatlásának mértékét vették számba, hanem a képességek több spektrumú értékelése, a társuló pszichopatológiai eltérések felmérése is megtörtént. Mint később dolgozatomban ismertetem, ezek a gondozás szempontjából alapvető jelentőségü tényezők.

Európa középső és keleti besorolású régióira vonatkozóan súlyozáson alapuló becslést közöltek, mely szerint a 60 év feletti lakosság 5,7-5,8 \%-a érintett demenciával.

iii. A demencia mint gazdasági tényező

A demencia esetében is alkalmazható az egészségügyi közgazdaságtan „képlete” a „betegségnek” a közösségre, a társadalomra háruló költségeiről. A költségeket alapvetően direkt, közvetlenül jelentkező és indirekt, közvetetten jelentkező csoportra osztja a szakirodalom (Gulácsi et al., 2012). Eszerint „direkt egészségügyi költségek” mindazok, melyek közvetlenül az egészségügyi ellátáshoz kapcsolódva jelentkeznek, míg a „direkt nem egészségügyi költségek" csoportjába azon költségek tartoznak, melyek a gyógykezeléshez kapcsolódnak ugyan, de nem az egészségügyi ellátórendszeren belül merülnek fel. Így az informális ellátás költségei is ide tartoznak. Az informális ellátás költségének összetevőit Krol és munkatársai (2015) ennél szélesebb értelemben definiálják, miszerint nem csupán az önkéntesként, fizetés nélkül ápolói tevékenységet végző rokon, barát ápolásra fordított idejét tekintik a költségszámítás alapjául, hanem e tevékenység hatására („mellékhatásaként”) jelentkező költségeket is, melyek az informális ápoló saját egészségének és jól-létének védelmére, helyreállítására fordított költségekből, akár nem-hivatalos kifizetésekből adódnak. 
A 2010-ben publikált World Alzheimer Report (ADI, 2010) hármas felosztásban tárgyalja a költségeket, miszerint

- direkt egészségügyi kiadások (kórházi- és járóbeteg ellátás, gyógyszerek),

- direkt szociális költségek (a nem egészségügyi, formális szociális ellátás költségei, ideértve a közösségi ellátási formák költségeit, mint például háziápolás, étkeztetés, szállítás, ápolási otthonban történő ellátás),

- informális ellátás költségei jelentik a harmadik egységet, melynél az informális ápoló különböző tevékenységekre fordított ideje jelenti a számítás alapját.

A demencia, ahogy más, gondozást igénylő kórképek, jelentős anyagi terhet ró a családokra, de ez a teher országonként jelentősen eltérő elsősorban a teljes jóléti és külön a szociális ellátórendszer eltérő struktúrája, támogatási potenciálja miatt. A családoknak először is jelentős bevételkieséssel kell számolniuk a demenciával élő személy, vagy a gondozását ellátó családtag, vagy mindkettőjük munkából való teljes vagy részleges kiesése miatt, mely összeg nagyságrendjére sincs becslés hazánkban.

Az Alzheimer Disease International (ADI) nemzetközi ernyőszervezet megbízásából 2015-ben Martin Prince vezetésével készült tanulmány szerint (ADI, 2015) a szociális ellátórendszer elégtelen funkciója miatt éppen az alacsony- és közepes jövedelmü országokban hárul nagyobb anyagi teher a családokra. Míg a magas jövedelmü országokban is valamivel meghaladják az informális ellátáshoz kapcsolódó költségek a formális szociális ellátórendszerre jutót, addig az alacsony- és közepes jövedelmű országokban a demencia-ellátással kapcsolatos költségeknek mindössze körülbelül a hatoda jut a formális szociális ellátásra.

iv. A demencia mint stratégiai tervezést igénylő társadalmi tényező

Egyes európai országok két évtizeddel előzik meg hazánkat a demencia jelentette társadalmi probléma felismerésében és a cselekvésben. Az első demencia akciótervét 2001-ben kihirdető Franciaország már a negyedik cselekvési programot hajtja végre, és felismerve az összehangolt cselekvés elönyeit, a demencia mellett további neurodegeneratív kórképekre is kiterjesztették annak alkalmazását. Az Esély folyóiratban 
megjelent publikációm (Fekete, 2019b) részletesen tárgyalja a rendelkezésre álló példákat, így erre részletesebben nem térek ki.

A stratégia elkészítésének szakmai megalapozása a bemutatott példák alapján többféle módon történt, de közös jellemzőjük, hogy többnyire a végrehajtásban majdan együttműködő szereplők minél szélesebb körének bevonására törekedtek. A Vezetéstudomány folyóiratban megjelent első publikációm (Fekete, 2017) egy kísérletet mutat be, ahol a részvételi rendszertérképezés módszerével, a demenciával élők életminőségét meghatározó tényezőket gyűjtötte össze a vegyes összetételű résztvevői gárda. Ez a kísérlet is megerősítette, hogy a részvétel biztosításával és a rendszertérképezés eszközével feltárhatóak egy adott érintett közösség prioritásai, melyek más példa szerint is (Király et al., 2016) a szakpolitikai döntésekhez hiteles hátteret biztosítanak.

\section{b. Társadalmi fenntarthatóság}

A fenntarthatóság fogalmának megszületését az 1987-ben „Közös jövőnk” (Our Common Future) címmel közzétett jelentéshez (WCED, 1987) kötik, melynek elkészítésére az Egyesült Nemzetek Szervezete (ENSZ) 1984-ben adott megbízást a Környezet és Fejlesztés Világbizottságnak (World Commission on Environment and Development), illetve az annak vezetésével megbízott Gro Harlem Brundtland asszonynak, aki után a jelentést gyakran Brundtland-jelentésként hivatkozzák. Az eredeti szövegben a fenntartható fejlődés definíciójaként a következőt olvashatjuk:

„Humanity has the ability to make development sustainable to ensure that it meets the needs of the present without compromising the ability of future generations to meet their own needs." (27. paragrafus)

Azaz:

„Az emberiségnek megvan a képessége arra, hogy a fejlödést harmonikussá tegye, vagyis biztositani tudja a jelen igények kielégítését anélkül, hogy veszélyeztetné a jövő generációinak lehetőségeit saját igényei kielégítésére.” (Persányi, 1988: 31) 
A környezet és gazdaság diszharmóniájának, a két terület közötti feszültségnek a 20. század közepétől észlelt növekedése vezetett ahhoz az igényhez, hogy definiálásra kerüljön, valójában mi a megoldandó feladat. Szükségessé vált továbbá olyan cselekvések meghatározása, amelyek az eltérő fejlettségű, képességű országok számára adaptálhatóak, hiszen az nyilvánvaló volt a kezdetektől, hogy egy globális, az egész világot érintő kihívással állunk szemben.

A jelentés három dimenziót azonosított, amelyek mentén a harmónia, a fenntarthatóság biztosításáról gondolkodni, gondoskodni kell. A környezet és a gazdaság mellett a harmadik dimenzió a társadalom, azaz maga az emberiség, aminek tulajdonképpen a fennmaradása a cél a harmonizáló erőfeszítések mögött. A fenntarthatóság biztosításának a kulcsa eszerint a versengő gazdaság, a környezet és a társadalom prioritásai közti egyensúlyozás (Boyer et al., 2016).

Tekintettel a kutatási fókuszomra, a társadalmi dimenziót kiemelem ebből a hármas egységből, elismerve azok szoros összefüggését. Megközelítésem alapja a környezet / ökoszisztéma, a társadalom és a gazdaság rendszerének azon viszonya, melyben ezek egyfajta háttérként, illetve befogadó rendszerként szolgálnak egymás számára (2. ábra) (Kerekes, 2009; McKenzie, 2004). Ez a beágyazott megjelenítés azt fejezi ki, hogy a környezet a legátfogóbb rendszer, amely magába foglalja a társadalmi rendszert, és a gazdaság rendszere csak ezen belül nyer létjogosultságot. A rendszerek között folyamatos interakció zajlik, oda-vissza irányú hatások eredményezik a fejlődésüket. Mindezek a folyamatok és eredmények a környezet, az ökoszisztéma jelentette globális kereten belül zajlanak, így hatásuk előbb-utóbb visszaüt, mivel a rendszerek müködése egymástól nem elválasztható. Ebből az ábrázolásból is levezethető, hogy bármely elem sérülése, fenntarthatatlanná válása a teljes rendszer összeomlásához vezet. 
2. ábra

A környezet - társadalom - gazdaság rendszerének viszonya (Forrás: saját szerkesztés)

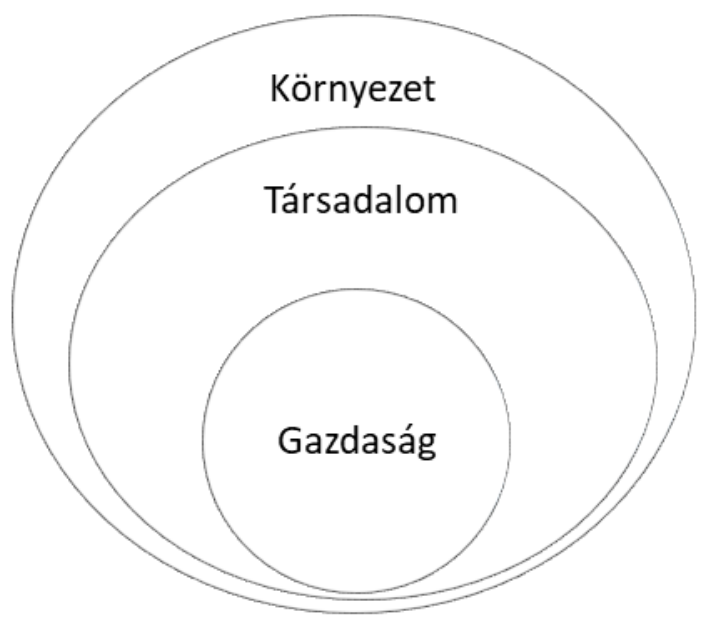

A fenntarthatóság társadalmi dimenziójának értelmezése ma is nyitott, annak ellenére, hogy már a Brundtland-jelentést megelőző évtizedekben felmerült a társadalom szerepének kérdése. Az 1968-ban megalakult Római Klub az 1972-ben „A növekedés határai" (The Limits to Growth) címmel kiadott (Meadows et al., 1972), a gazdasági növekedés fenntarthatatlanságával és annak lehetséges negatív hatásaival foglalkozó első jelentésében az exponenciális, korlátlan növekedés korlátait két kategóriára osztották. A növekedés fizikai szükségleteit - mint az élelmiszerek, a friss víz, erdők, óceánok vagy a különféle nyersanyagok - sorolták a szerzők az egyik csoportba, melyek az élettani és ipari müködés alapfeltételeit jelentik. Ezek a dolgok többnyire kézzelfoghatóak, megszámlálhatóak, számontartásuk, mennyiségük követése módszertani szempontból egyszerü. A növekedés szükségleteinek másik csoportját olyan, úgynevezett társadalmi szükségletek alkották, mint a béke, társadalmi stabilitás, oktatás, foglalkoztatás, technológiai előrehaladás, melyek esetén konkrét, jól definiálható változókkal bíró mérési módszerek kevésbé alkalmazhatóak, előrejelzés is több bizonytalansággal fogalmazható meg.

Murphy (2012) irodalmi áttekintés alapján alkotott egy fogalmi keretet a még akkor is hiányos meghatározottságú harmadik dimenzió definiálására, a fenntartható fejlödés társadalmi pillérének körülírására, és a környezeti pillérhez való viszonyának 
maghatározására. A négy kirajzolódó szakpolitikai megközelítése a társadalmi pillérnek a társadalmi tudatosság (public awareness), a méltányosság (equity), a részvétel (participation), a társadalmi kohézió (social cohesion). Murphy (2012) - összegezve az elődök fogalommal kapcsolatos megállapításait, amelyek szerint az homályos és elvont szükségét érezte, hogy a másik két pillér mellett mostoha helyzetủ társadalmi dimenzió meghatározását segítse összegző munkájával. Kiemeli, hogy a társadalmi megközelítés az addigi koncepciókban többnyire a jelen generációk jólétére vonatkozó célkitüzésekre korlátozódik, holott a generációk közötti és a nemzetközi kapcsolat is megfontolásra érdemes szakpolitikai megközelítés lenne.

Boyer és munkatársai (2016) a társadalmi fenntarthatóság különböző megközelítéseit összegző munkájában szintén keresték a magyarázatot a téma mostohának ítélt voltára. A feldolgozott, az addig a témával foglalkozó munkákban felvetett okok alapján egyrészt történelmi hagyománnyal, a fenntarthatóság elsődlegesen „zöld”, azaz környezeti problémaként való azonosításával magyarázták, másrészt azzal, hogy a társadalmi valóság összetettsége elsőre lehetetlennek mutatja objektív megállapítások megtételét. Az mindenképp igaz, hogy a fenntarthatóság tárgyalásának e szempontja került legkésőbb a fogalomrendszerbe, és a diskurzus így sokáig hangsúlyosan a környezet és a gazdaság viszonya körült folyt, bár mára nem kevesen központi kérdéssé emelték a társadalmi fenntarthatóságot.

Ahogy a fenntarthatósági elméletek sem egységesek, úgy a társadalmi fenntarthatóság definícióját keresve sem található egy egységesen elfogadott fogalommagyarázat. Vannak holisztikus, átfogó és redukcionista, leegyszerüsítő megközelítések. A holisztikus megközelítésre jellemző az interdiszciplinaritás, de ilyenkor is jellemző a bevont tudományágak szürőjén keresztüli megközelítés, akár az elöre feltételezett összefüggések mentén folyó témafeltárás.

Boyer és munkatársai (2016) összegző munkájukban öt értelmezési, megközelítési irányvonalat különítettek el az aktuálisan elérhető tudományos források áttekintése alapján (Fekete, 2018, 285-6.o.). ${ }^{9}$ Az öt megközelítés szerint tehát a társadalmi fenntarthatóság értelmezhető mint:

\footnotetext{
${ }^{9}$ A következő 5 bekezdés a szerző által írt „Társadalmi fenntarthatóság” című tankönyvfejezet (in Feith, H.J. szerk. 2018. Társadalom, család, egészség - Családtudományi alapismeretek. Semmelweis Egyetem Egészségtudományi Kar, 285-286.o.) alapján, azt minimálisan kiegészítve ismerteti a társadalmi fenntarthatóság értelmezési formáit.
} 
1. különálló cél

2. a gazdasági és környezeti tényezők kontrollja alatt álló kötelezettség

3. a környezeti és gazdasági fenntarthatóság előfeltétele

4. a gazdasági és környezeti változások okozója

5. hely-központú, folyamat-orientált fenntarthatóság.

A társadalmi fenntarthatóság különálló célként való feltüntetése, azaz az eredeti 3-pillérü modell 1-pillérüvé alakítása mindenképpen hátrányos abból a szempontból, hogy a gazdasági, környezeti és társadalmi folyamatokat egymástól függetlennek tünteti fel, és figyelmen kívül hagyja a rendszer közti törvényszerü kapcsolatokat, interakciókat (Griessler és Littig, 2005) (1.). Más megközelítésben a három rendszer egymást kontroll alatt tartja, de ahogy egyes szerzők rámutatnak, ez a megközelítés nem feltétlenül vezet az eredendő cél, az ökoszisztéma fennmaradásához. Az üzleti fenntarthatósági beszámolók példáján keresztül vezeti le Milne és Gray (2013), hogy fennáll a veszélye annak, hogy éppen a fenntarthatatlanságot szolgálja, ha a három fogalmat - ahogy fogalmaznak - elhomályosítják, és a gyakorlatban egyesíteni próbálják a környezeti, gazdasági és társadalmi célokat (2.). Az az elmélet, amely a társadalmi tőkét helyezi előtérbe, a társadalmi fenntarthatóságra úgy tekint, mint ami a környezeti és gazdasági fenntarthatóság előfeltétele; a társadalmi tőkét pedig a társadalmi fenntarthatóság nélkülözhetetlen vagyonelemének tartja. A társadalmi fenntarthatóságnak az épített környezetben való értelmezésében kiemelt figyelmet kap a társadalmi egyenlőség és igazságosság és a közösség fenntarthatósága (Dempsey et al., 2011) (3.). Egy újabb elmélet még határozottabban fogalmazva, a társadalmi fenntarthatóságot egyenesen oksági tényezőként tünteti fel, és a társadalmi igényekből, az alternatív gondolkodásból, megközelítésből következő kezdeményezések sorát hozza fel példaként - például a fenntarthatatlan fogyasztás mérséklését vagy a takarékosabb vízfogyasztást célzó közösségi kezdeményezéseket -, amikor a cél végeredményben a gazdasági és környezeti fenntarthatóság biztosítása. Ez az értelmezés hangsúlyozza az új igények megfogalmazásán alapuló kutatási és fejlesztési tevékenység ösztönzésének szükségszerűségét (Seyfang és Smith, 2007), valamint a társadalmi kapcsolatok és a társadalom szerveződési módjának, a kultúrának a szerepét a fenntarthatóság problémájának megoldásában, és erre egyik lehetőségként a helyi, közösségi 
döntéshozatalban láttatja a megoldást (4.). Az utolsó elmélet szintén előtérbe helyezi a „helyi”, lokális megközelítést (Cowling et al., 2008), ahol helyi problémákra, helyi motivációval, helyi cselekvésekkel kívánnak előrelépést elérni a fenntarthatóság területén úgy, hogy a fenntarthatóság három rendszerének átfedését tekintik alaptézisnek, kiemelve a többfókuszú, interdiszciplináris megközelítés fontosságát (Raymond et al., 2010) (5.).

A társadalmi fenntarthatóság fogalma tehát összetett; leírása, meghatározása nem préselhető néhány sorba. A fenntarthatóság problémájának sokak szerint a legkevésbé körüljárt és tudományos alapossággal vizsgált területe, talán éppen azért, mivel a legkevésbé konkrét. Mindenképpen kevésbé konkretizálható az érintendő témák köre, mint a környezeti, ökológiai ágnak, ahol egyértelmü a fenyegető veszély - mely az egész fenntarthatósági „mozgalmat” életre hívta - és a végső kimeneti cél. Sokak szerint a leginkább holisztikusan, interdiszciplinárisan megközelíthető pillér, ami gondolkodói, kutatói oldalról azt is jelenti, hogy kiaknázatlan lehetőségeket rejt a témában való elmélyedés. A fenyegető, illetve fennálló társadalmi válság szintén legalább annyira megoldásért kiált, mint a környezeti.

Ahogy a Római Klub tanulmánya a fejlődés társadalmi feltételeit megfoghatatlanként, összeszámlálhatatlanként írta le, úgy megfelel ennek a megközelítésnek az a vélekedés, hogy a társadalmi fenntarthatóság tulajdonképpen közösségi és politikai értékek fenntartásáról, megőrzéséről, fejlesztéséről kell, hogy szóljon. A társadalmi értékek, normák, a nyelv, az oktatás, a hatalmi rendszer jelentős hatással vannak a társadalmi kapcsolatokra. A társadalmi, vagy inkább közösségi és az egyéni fejlődés így külön-külön és együtt is értelmezhető és értelmezendő a társadalmi fenntarthatóság keretein belül.

A társadalmi fenntarthatóság értelmezéseinek Boyer-féle összegzésénél (Boyer et al., 2016) is láthattuk, hogy több megközelítésben hangsúlyos szerepet kap a közösség. Van, ahol elsődleges, oksági tényezőnek tartják, azaz az értelmezés szerint közösségi akarat, közösségi célkitüzés vezetett egyáltalán a gazdasági és környezeti fenntarthatósági cél kitüzéséhez. Máshol a társadalmi szerveződés módja a kulcs, a helyi közösségek lokális problémafelvetését és a helyi döntéshozatalba való bevonódását tekintik a fejlődés útjának. Saját munkáim is foglalkoznak ezzel az aspektussal, hol a gyakorlati megvalósítás (Fekete, 2017), hol pedig az elméleti háttér (Fekete, 2019b) szempontjából.

Kutatási fókuszom mentén a társadalmi fenntarthatóságra mint közösségi felelősségre tekintek. Az informális ápolás, a családon belüli gondozási tevékenység jelentősen 
hozzájárul a társadalmi olló kinyílásához, a társadalmi egyenlőtlenség növekedéséhez, mivel végzése éppen azok számára kényszerüség, akiknek a jövedelemszerző képessége gyengébb. Az elöregedő és a bármilyen funkcionális korlátozottsággal élőket egyre nagyobb számban és arányban magába foglaló társadalmak növekvő problémája lesz az igazságosság kérdése. A társadalmi fejlődés - következő fejezetben tárgyalt - mérési módszerének tekintett jól-lét esetében is különbségek növekedése várható, így kiemelt jelentőségű, hogy a jól-létet meghatározó tényezőket egyéni szinten feltárjuk, és a közösségi, társadalmi beavatkozás lehetőségeit megtaláljuk és sikeresen alkalmazzuk.

Említésre érdemes az az elmúlt évtizedekben tapasztalható folyamat, miszerint a közösség egyre nagyobb szerepet játszik a saját élete alakításában. Ma már nem csupán a közösség érdekét szolgáló, külső kezdeményezésre és irányítással zajló változások megvalósításában vesznek részt tagjai. Mint a társadalmi fenntarthatóság értelmezési lehetőségei között is megjelent, a társadalom, egy közösség igényformáló szereplővé, katalizátorrá vált. A katalizátor szerepet a közösség nem csupán az igények felvetése, hanem konkrétan kutatásban, fejlesztésben való részvétel útján is betöltheti. A civil tudomány (citizen science) demenciához kapcsolódó példáját az. 1. Mellékletben ismertetem.

\section{c. Jól-lét és életminőség}

A fenntarthatóságnak, a fenntartható fejlődésnek nem csupán a társadalmi dimenziójáról mondható el, hogy értelmezése, fogalmi meghatározása erősen célfüggő, hanem legalább ennyire igaz ez a gazdasági dimenzióra is. Következésképpen azt is problematikus egyszerüen definiálni, hogy mi is az, aminek a fenntartására törekedni kell. A megközelítésbeli különbségek mellett mindenesetre közös a jövőre irányuló szemlélet, az, hogy valamit a jövőre vonatkozóan kívánunk megőrizni, fenntartani (Gébert, 2015). A környezeti dimenzió szempontjából a legegyszerübb talán ezt egy szóval meghatározni, hiszen nem érdemes kisebb célt, mint a teljes ökoszisztémának a fenntartását kitűzni. A témával foglalkozók természetesen ennél sokkal színesebben tudják meghatározni a célokat, amelyek az ENSZ által 2015-ben 2030-ig történő megvalósítással kihirdetett Fenntartható fejlödési célok (United Nations, 2015; KSH, 2015) mentén három nagy 
csoportra oszthatók, úgymint: fellépés az éghajlatváltozás ellen, óceánok és tengerek védelme, szárazföldi ökoszisztémák védelme.

A gazdasági dimenzió szempontjából a fenntartható fejlődés kulcsfogalomra gondolva megint viszonylag egyszerünek tünik a kérdés, hiszen valamilyen fejlődési mérőszámot kell találni. A különböző közgazdasági iskolák, irányzatok azonban más-más megközelítéssel tekintenek magára a fejlödésre, így a mérendő tényezőt is másképp határozzák meg (Gébert, 2015). A gazdasági prosperitás mérőszámai közül a legtöbbet kritizált - talán éppen a leggyakoribb használat okán - a GDP (gross domestic product), azaz a bruttó hazai termék mutatószáma. Különösen erős a kritika a társadalmi fejlődéssel foglalkozók irányából, mivel - ahogy arra később kitérek - számos, az egyén és a közösség szempontjából fontos, értékkel rendelkező tevékenység marad láthatatlan a GDP alapú megközelítés esetén.

Ide kívánkozik az 1998-ban Nobel díjjal elismert közgazdász, Amartya Sen fenntarthatósági megközelítésének, az úgynevezett képességszemléletnek (capabality approach) a kiemelése, mivel az nem valamely tökealapú fejlődést/növekedést, hanem a képességek, lehetőségek meglétét tekinti változáskövetésre érdemes paraméternek (Gébert, 2015). Sen 1970-től publikálta a társadalmi- és gazdasági fejlődés egyéni megközelítését ismertető műveit, melyben az elsődleges szakpolitikai célként a képesség megteremtését jelölte meg. A képességek kiterjesztése által az egyének egyfajta cselekvési szabadsághoz jutnak, mivel képessé válnak számukra értékes dolgok megtételére, és számukra értékes létállapotok elérésére. Mindez pedig közösségi szinten igazságosságot is eredményez, ha az értékes képességekhez való hozzáférés egyenlően biztosított (Pataki, 1998). Nem vitatható, hogy az anyagi javak birtoklása is egyfajta szabadságot biztosít jelen társadalmunkban, hiszen további javak megszerzésének képességével ruházza fel az egyént. Ebben az értelemben a - GDP-vel is mérhető gazdasági gyarapodás viszont csupán eszköz. Eszköz arra, hogy jobb életminőséget teremtsünk. Jogosultságok és képességek szükségesek ahhoz, hogy az eszközök alkalmazásával valamely értékes célt el is lehessen érni.

Egy pillanatra az elméleti háttér tárgyalása közben felidézve azt a társadalmi problémát, a demenciát, amely motorja ennek a munkának, érdemes elgondolkodni azon, hogy a tünetegyüttest éppen egy olyan kulcsfontosságú képesség elvesztése jellemzi, amely az érintett egyént, illetve a gondozásban részt vevő családtagokat is megakadályozza abban, 
hogy más képességeiket, elvi szabadságukat gyakorolják. Ahogy Sen a szegénységen, mint deprimált állapoton keresztül mutatja be a képességszemléletet, meghatározásai direkt alkalmazhatónak tünnek erre a hátrányos helyzetű csoportra - demenciával élőket és gondozóikat közös érdekcsoportnak tekintve. Minden kitétel igaz esetükben, amelyeket Sen például a szegénység problémájával kapcsolatban megfogalmazott (Sen, 1999), kezdve az abszolút és relatív elkülönítésétöl, az abszolút megközelítésnél a betegség - határok meghatározásán át, az abszolút és relatív közötti határ elmosódásáig. Végeredményben Sen szavaival élve a demencia esetén is alkalmazható az a „túlegyszerüsítés”, miszerint „egy abszolút kategória” - tekintettel a mind kifinomultabb orvostudományi meghatározásokra -, ugyanakkor ,igen gyakran relatív formát ölt” - ha nem is a javak -, de a „tulajdonságok” és körülmények tekintetében mindenképp. Egészen más képeségekkel rendelkezik egy nagyvárosi, stabil anyagi és társadalmi védőhálóval rendelkező, támogató - támogatásra hajlandó és képes - családdal körülvett demenciával élő személy, mint egy egyedül álló, egyedül, teljes elszigeteltségben élő, a közvetlen környezetében lakók érzékenységének és felelősségvállalási hajlandóságának kiszolgáltatott beteg.

A társadalmi dimenzió szempontjából a fenntarthatóság és fejlődés jelenleg elfogadott mérési megközelítése egy több évtizedes folyamat eredménye. Tekintettel arra, hogy a fenntarthatóság társadalmi dimenziója nem került azonnal az érdeklődés középpontjába, így tulajdonképpen volt idő arra, hogy mire a közgazdászokat ez a téma érdekelni kezdte, addigra más társadalomtudományi területek müvelöi megtegyék a kezdeti lépéseket a megfelelő mérőeszközök, módszerek megtalálása felé. Alapvetően a pszichológusok terepe az emberek szellemi fejlődésének, jó állapotának követése, ami evidens célként jelölhető meg, ha egyén vagy közösség/társadalom szintjén az állapot jobbá, fenntartandóvá tételének igényéböl indulunk ki. A jól-lét (well-being) fogalmának a fenntarthatóság szempontjából megalapozott használatáig hosszú út vezetett, de végeredményben a tudományterületek közötti együttmüködés jó példáját is prezentálja.

Ahogy Frey és Stutzer (2002) kifejti:

„A boldogságot általában az élet végső céljának tekintik; lényegében mindenki boldog akar lenni." (Frey és Stutzer, 2002; 402.o.)

A boldogság tehát egy értelmezhető cél a közgazdaságtan számára, azonban sokáig problémát jelentett a mérése. Egy fontos lépés kötődik Ed Diener nevéhez, aki felismerve 
a mérési igényt, a szubjektív jól-lét (subjective well-being) fogalmának aktuális konceptualizációjára vállalkozott a 80-as évek közepén (Diener, 1984). Olyan addigi dogmák megdöntésére vállalkozott, mint hogy a fiatalok, vagy akik egészségesebbek, boldogabbak. Az - irányzatként később definiált - pozitív pszichológia képviselőivel összhangban problémának látta, hogy a pszichológiára alapvetően negatív megközelítés a jellemző, azaz a „,boldogtalanság” okának feltárása a célja.

A pozitív pszichológia megalapítójának tekintett Martin Seligman és a szintén optimista megközelítéssel foglalkozó Csíkszentmihályi Mihály 2000-ben az American Psychologist pozitív pszichológiának, mint új, feltörekvő irányzatnak szentelt millenniumi különszáma bevezetőjében összegzi (Seligman és Csikszentmihalyi, 2000): a pszichológia tudománya a II. Világháború után a szenvedés enyhítésére, a lélektan patológiai megközelítésére koncentrált, és nem fordított figyelmet a pozitív egyéni és közösségi folyamatokra. Mintegy az egészségügyi rendszernek egy alegysége az „áldozattan” szerepét töltötte be. Hitvallásuk szerint a pozitív pszichológia célja a fókusz módosítása, a pozitív tulajdonságok erősítésére koncentráló megközelítés kialakítása. E millenniumi lapszámban is helyet kap Diener, de később Seligmannal közös alkotói munkát is végzett (Diener és Seligman, 2004). Publikációjukban a jól-lét gazdasági mutatóként való alkalmazása mellett állnak ki. Felhívják a szokásosan alkalmazott gazdasági mutatók (pl. GDP) hiányosságaira a figyelmet - mint írják, a gazdasági fejlődés kezdetén volt nagy jelentősége a csupán gazdasági indikátoroknak, amikor az alapszükségletek megteremtése volt a cél, de ennek a célnak a túlhaladásával a mérőeszközön változtatni szükséges. Példaként említik, hogy egyre több mentális betegséggel küzdő ember van, akiknek a jól-létén a gazdasági mutatók javulása nem segít, sőt paradox módon, a betegség kezelése generálta szolgáltatás és fogyasztás gazdasági szempontból pozitív hatású. Meglátásuk szerint a jól-lét biztosítása nem csupán a ,jó érzés" miatt fontos, hanem annak pozitív - például a foglalkoztatásban megjelenő következményei miatt is. A jól-léti célkitüzéseknek tehát politikai szerepük, politikabefolyásoló hatásuk kell, hogy legyen, és ezt elősegítendő javasolják nemzeti jóllét index kidolgozását. Az indikátorrendszerrel kapcsolatos víziójukban a következőket összegzik: az indikátorrendszer tartalmazzon a döntéshozatal szempontjából releváns kérdéseket; különböző érdekcsoportokat reprezentáljon; a jól-lét széles értelmezését, így az élettel való elégedettséget, az élet célját és értelmét, a bizalmat, az elkötelezettséget, a depressziót, valamint pozitív és negatív érzelmeket is jelenítsen meg; a mindennapi élet 
bizonyos szükebb aspektusaira - mint munka, egészség, család, közösség, szabadidő vonatkozó információkat is tartalmazzon; állandó és aktuális intézkedési tervekhez kapcsolódó kérdéseket is foglaljon magába; valamint mind az almintákat érintő mélységi, mind pedig a változások követésére alkalmas hosszmetszeti módszert alkalmazzon.

A jól-lét mérése megalapozottságának konszenzusáig azonban még további tudományos diskurzus is szükséges volt, egyrészt a szubjektivitás „,védhetősége”, másrészt az érzelmi vs. kognitív tartalom különbözősége miatt. A hedonikus jól-lét (hedonic well-being) és az eudaimonikus jól-lét (eudaimonic well-being) perspektívákat Ryan és Deci, mint ellentétes, ugyanakkor egymást kiegészítő megközelítéseket tárgyalja (Ryan és Deci, 2001). A szerzők „optimális pszichológiai müködésként” összegzik a jól-lét fogalmát. A hedonikus és eudaimonikus szemlélet hátterében számos szerző utal az ókori görög filozófiai gyökerekre. A hedonikus jól-lét definícióját többekhez - köztük Platónhoz vezetik vissza, de az eudaimonikus szemléletet jellemzően Arisztotelésznek tulajdonítják (Diener, 1984; Ryan és Deci, 2001). A hedonikus megközelítés egyfajta mérlegelést jelent, ahol a pozitív irányba való elbillenést a bánatot és fájdalmat meghaladó örömérzet eredményezi (Wiseman és Brasher, 2008), vagy egyszerűen a boldogság oka az, hogy egy vágy beteljesül (Ryan és Deci, 2001). Más megvilágítás szerint a kellemes élmények maximalizálása a rossz élményekkel szemben biztosítják a lehető legmagasabb szintű jóllétet (Vanhoutte, 2012). A hedonikus jól-létnek affektív/hangulati és kognitív/gondolati ágát is meg lehet különböztetni (Vanhoutte, 2012), de ez talán az indikátorok túlzott felcímkézését eredményezi, és elegendő annak belátása, hogy a hedonikus jól-lét fogalma önmagában is összetett. A lehangoltság érzésének vagy az általános egészségi állapotnak az értékelése értelemszerűen a hangulati ághoz sorolható, míg az élettel való elégedettségről szóló megnyilatkozás egy tudatosabb mérlegelési folyamat eredménye.

Az eudaimonikus megközelítés ennél összetettebb, egészen a Maslow-féle szükséglethierarchiáig visszavezethető, miszerint az önmegvalósítás (self-actualisation) emberi szükséglet, tehát az értelmes, céllal rendelkező élet „élése” önmagában boldogságforrásként szolgál (Vanhoutte, 2012). Nem pusztán egy megélt eredmény, hanem az ahhoz vezető út kerül így értékelésre. Az is lehetséges ugyanakkor, hogy egy beteljesedett vágy nem eredményez jó érzetet, mivel maga az oda vezető folyamat nem volt jól-lét fokozó hatású (Ryan és Deci, 2001). A saját munkám során is alkalmazott, illetve részletesen kutatott, idősekre szabott életminőséget vizsgáló eszköz a CASP (Control, Autonomy, Self-realization, Pleasure) (Hyde et al., 2003) is egy olyan 
konstrukció, melynek célja a végeredmény (jól-lét) és az arra vezető állapotok elkülönítése.

Mára a két szemléletmódot képviselök közötti vita nyugvópontra került, mivel elfogadottá vált, hogy a jól-lét hedonikus és eudaimonikus értelmezésének komponensei egyidejüleg befolyással bírnak (Ryan és Deci, 2001). Ugyanakkor nem lehet azt mondani, hogy a „szubjektív adatok mérésének” létjogosultsága mindenki számára megnyugtató lett volna. Kahneman és Krueger (2006) a szubjektivitás mellett pozitívumként azt hozza fel, hogy az az egyéntől közvetlenül, direkt módon nyert adat, amely tapasztalást és érzést regisztrál. Ennek szerepét azonban a hagyományos hasznosságalapú koncepcióba építve vázolják, mint az emberi választást motiváló tényezők egy új csoportját. Előrevetítik, hogy a szubjektív jól-lét mérés hatással lesz a jólét meghatározásának módjára is, valamint, hogy a jólét maximalizálása felé nem a fogyasztás, hanem a társadalmi kapcsolatok növekedése visz közelebb.

Az ezredforduló után tehát már nem volt kétséges, hogy a gazdasági fejlődést, az anyagi gyarapodást, a jólétet (welfare) nem lehet direkt megfeleltetni az egyének boldogságával, vagyis az addigra megtalált konszenzusos megnevezésű jól-léttel (well-being). Ennek eléréséhez fontos mérföldkő volt a Fitoussi-jelentés (Stiglitz-Sen-Fitoussi, 2010) ${ }^{10}$, melynek elkészítésére 2008-ban Nicholas Sarkozy akkori francia elnök kért fel neves szakértőket (Jean Paul Fitoussi, Joseph Stiglitz, Amartya Sen - "The Commission on the Measurement of Economic Performance and Social Progress" - Bizottság a gazdasági teljesitmény és a társadalmi fejlödés mérésére) azzal a céllal, hogy azonosítsák a GDP, mint mutatószám, korlátait, valamint javaslatot tegyenek olyan indikátorok és statisztikai elemzések alkalmazására, amelyek közelebb visznek a gazdasági teljesítmény és a társadalmi fejlődés megfelelőbb követéséhez. Mindezt annak érdekében, hogy ezek kedvező irányú befolyásolására megfelelő politikai tervek készülhessenek. A jelentést ugyanakkor széleskörü felhasználásra szánták: a politikusokon túl döntéshozóknak, a tudományos közösség tagjainak és a civil szervezeteknek, és tulajdonképpen a társadalom minden tagjának - nem csak Franciaországban. Ezen a jelentésen alapul az OECD (Organisation for Economic Co-operation and Development - Gazdasági Együttmüködési és Fejlesztési Szervezet) 2011-ben kiadott, a jól-léti indikátorokat

\footnotetext{
${ }^{10}$ Report by the Commission on the Measurement of Economic Performance and Social Progress. (Online elérhetö: http://ec.europa.eu/eurostat/documents/118025/118123/Fitoussi+Commission+report Letöltve: 2018.08.05.)
} 
összegző tanulmánya (OECD, 2011). Ebben az emberi jól-létet meghatározó tényezőket két csoportra osztják (3. ábra). Az egyikben az „,anyagi életkörülmények” összetevői szerepelnek, melyek a jövedelmi és vagyoni helyzetet írják le, míg a másik adathalmaz az ,életminőség” gyüjtőfogalma alatt sokkal színesebb forrást biztosít a jól-lét leírásához. Ebben a csoportban kapott helyet számos szubjektív állapotleíró elem, valamint az egyénnek a társadalomban való boldogulását, a családban való szerepvállalását is meghatározó tényező, de a környezet és az ember interakciójára vonatkozó jellemző is ebben a csoportban kerül számbavételre.

3. ábra: A jól-létet meghatározó tényezők - OECD jól-léti indikátorok (Forrás: Compendium of OECD Well-Being Indicators, 2011.; saját szerkesztés)
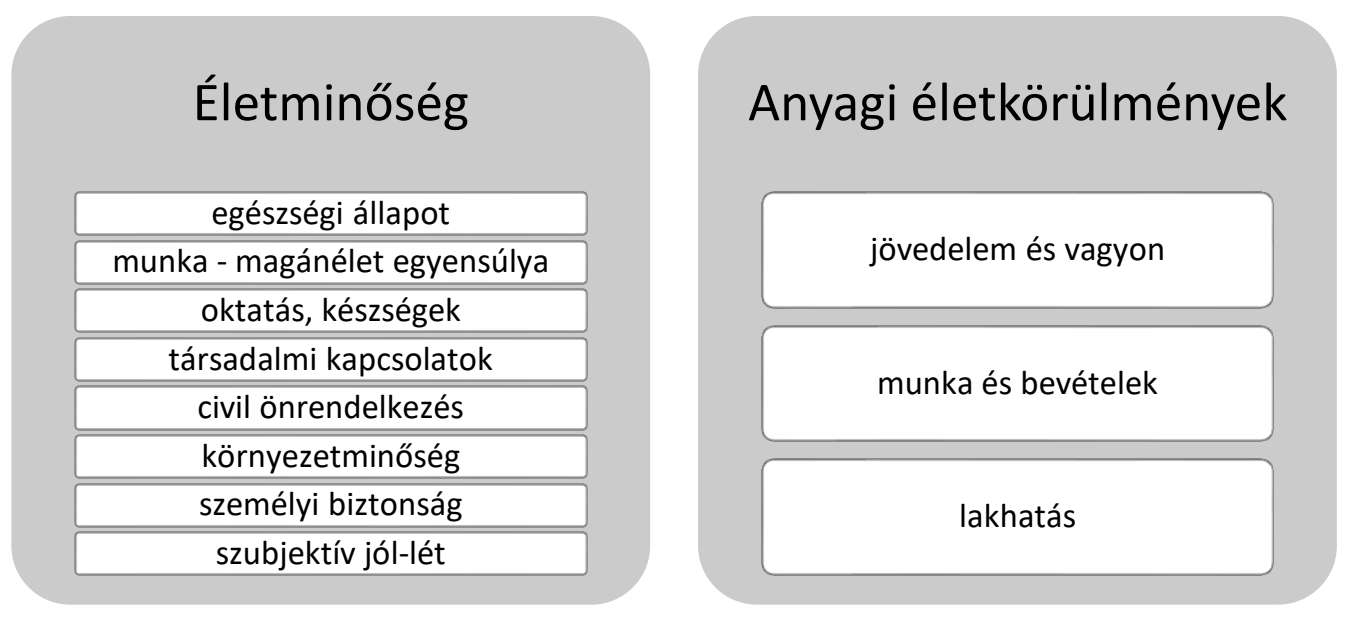

Ahogy a társadalmi fenntarthatóság a közösségek fennmaradásának és fejlődésének mikéntjével foglalkozik, úgy ennek követésére alkalmas mérőmódszereket is fel kellett vázolni. Az egyének jól-léte nem összegezhető matematikailag annak érdekében, hogy abból megkapjuk egy adott közösség fejlődésének mértékét. Ehhez természetesen először definiálni kell, hogy mit is értünk közösségi jól-lét alatt. Wiseman és Brasher (2008) szerint:

„A közösségi jóllét a társadalmi, gazdasági, környezeti, kulturális és politikai körülmények kombinációja, amelyet az egyének és közösségeik alapvetö fontosságúnak tartanak a virágzásukhoz és a lehetőségeik kiteljesitéséhez." (358.o.) 
A közösségi jól-lét tehát az egyéni jól-lét meghatározásánál is összetettebb, végképp nem mérhető fogyasztási alapon a hagyományos jóléti megközelítéssel, ugyanakkor várható, hogy a közösségben az egyéni jól-létet befolyásolja a közösségben, társadalomban betöltött szerep (Kahneman és Krueger, 2006). Több ez irányú kutatás igazolta, hogy az egyén és a közösség jól-létének ráadásul kölcsönös hatása van egymásra (Theodori, 2001).

\section{d. A társadalom elöregedése}

A társadalom elöregedése kiemelt jelentőségű tényezője a társadalmi fenntarthatóságnak. A korstruktúra megváltozása mind globálisan, mind lokálisan, a helyi közösségek szintjén a társadalmi folyamatokat befolyásoló szereppel bír.

Az „ageing” (population ageing), magyarul leginkább használatos formájában a társadalom elöregedése egy manapság már ismert, sokszor hivatkozott fogalom. Fontos azonban egy kicsit a fogalom mögé nézni, hiszen már az öregség, az öregkor fogalma sem határozható meg egyszerüen, nem adható meg értéke egy numerikus skálán. Jackson (2007) a társadalom elöregedését egy jelenségként (phenomenon) írja le, amelynek négy dimenzióját definiálja:

1. számszerü öregedés (numerical ageing), azaz az időskorúak számának abszolút növekedése;

2. strukturális öregedés (structural ageing), azaz a társadalmon belül az idősek arányának növekedése;

3. természetes hanyatlás (natural decline), akkor következik be, amikor a halálozások száma meghaladja a születések számát - ez a folyamat a számszerü öregedés velejárója, hiszen senki nem élhet örökké;

4. abszolút hanyatlás (absolute decline), akkor áll elö, amikor a csökkenő születésszám és a növekvő halálozás miatt bekövetkező népességfogyást a népvándorlás nem tudja kompenzálni.

A négy dimenzió egy adott populáció korösszetételét, „korát” meghatározó három tényező - fertilitás, várható élettartam, migráció - alakulásával áll összefüggésben. A számszerü öregedés egyenes következménye a várható élettartam növekedésének, mely 
már nem csupán a fejlett, hanem a fejlődő országok jellemzője is. Az élettartamnövekedésen túl a csecsemö- és gyermekhalandóság drasztikus csökkenése is hozzájárul a számszerü növekedéshez. A korcsoporti arányok eltolódása, azaz a strukturális öregedés elsősorban a fertilitás alakulásának, a születésszám változásának a követkeménye. Bár a II. világháború után számos országban tapasztalható volt a gyermekvállalási hajlandóság növekedése (baby boom), ezek a népesedési cunamit kiváltó folyamatok helyenként eltérő indíttatásúak, következményesen eltérő lefolyásúak, tartamúak voltak. Magyarországon ezen időszakon belül egy rövid - alig több mint 1 éves - tartamú, további 2-3 év alatt lecsengő hatású, agresszív népesedéspolitikai intézkedéscsomaghoz köthető születésszámkiugrás a mai napig komoly hatással bír (Tárkányi, 1998; Bódy, 2017). Az úgynevezett Ratkó-korszak gyermekei és unokái a hazai korfán egyértelmű nyomot hagynak (4. ábra).

4. ábra: A Világ, Európa és Magyarország korfája 2019-ben (Forrás: https://www.populationpyramid.net/hungary/2019//) ${ }^{11}$
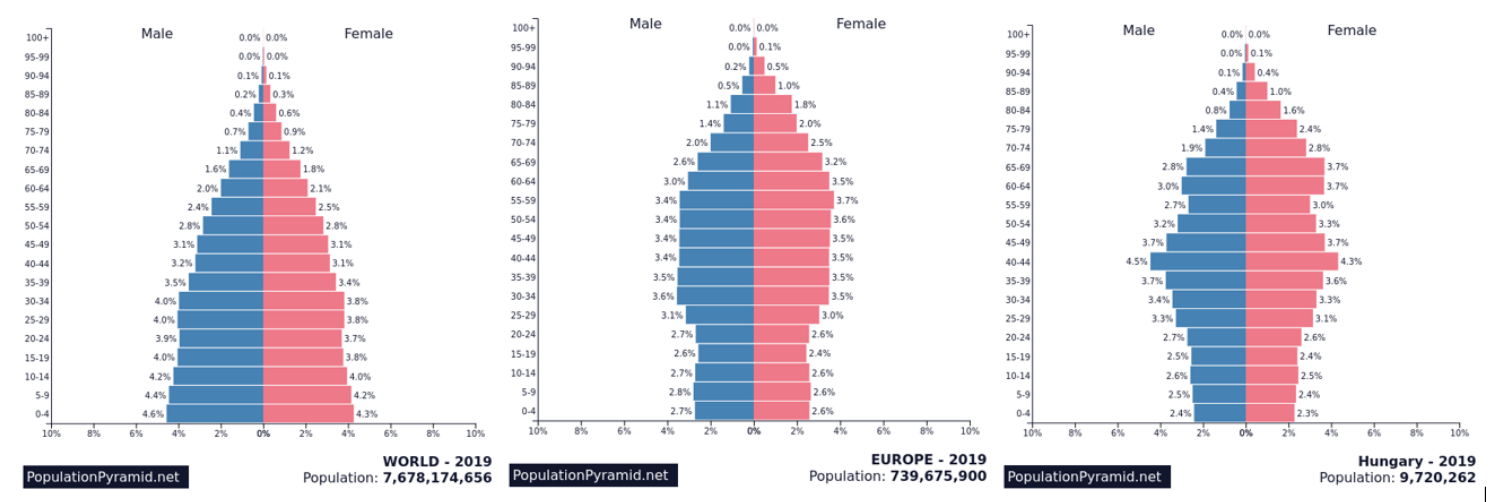

A Föld népessége gyarapodásának egyik sarokpontja a második világháború utáni időszakban tapasztalható ugrásszerü fertilitásnövekedés, mely számos országot jellemzett, ha nem is pontosan azonos ütemben. Ez az angol terminológia szerint „,baby boomer" korosztály biztosította a gazdasági fejlődéshez a humánerőforrást, akik viszont a jelen évtizedre nyugdíjas korúvá váltak, majd az egészségi állapotuk hanyatlása miatt hamarosan a gondozásra szorulók tömegét gyarapíthatják. A baby boomer csoport öregedésének következménye a 2012-ben bekövetkezett demográfiai fordulópont (World Bank Group, 2016), amikor a munkavállaló korúak csoportja (15-64 év közötti korosztály) elérte a globális népességen belüli arányának a csúcsát 65,8\%-on. Ha az 1950-

${ }^{11}$ Letöltve: 2019.09 .01$. 
es évektől napjainkig terjedő, körülbelül két emberöltőnyi időszak alatt bekövetkező demográfiai folyamatokat röviden összegezzük, akkor azt a fertilitási ráta megfeleződése $(5 / 2,5)$, és a mortalitás csökkenése miatt a várható élettartam jelentős, mintegy két és fél évtizedet kitevő növekedése (1950: 46,8 év / 2015: 71,7 év) jellemzi.

Aktualitást a baby boomer-ek kiemelésének a közelgö, illetve már zajló nyugdíjba vonulásuk, valamint ápolási igényük megjelenése ad. Jackson (2007) azért tartja fontosnak a számszerű és strukturális elöregedés elkülönítését, mivel az előbbi elkerülhetetlenül és gyorsan zajlik, addig a strukturális változás ennél valamivel lassabb, így a szakpolitikának lehetősége lenne a változásokra felkészülni. Az informális ápolás szempontjából különösen fontos az arányok megváltozása, tehát a strukturális vagy szerkezeti elöregedés. A számszerü öregedés, az időskorúak abszolút számának növekedése pedig a jólléti ellátórendszerek kapacitástervezése szempontjából mérvadó.

A hazai demográfiai tendenciát az Esély folyóiratban megjelent tanulmányom (Fekete, 2019b) 1. ábrája alapján szemléltetem (5. ábra).

5. ábra. Magyarország lakosságának korcsoportonkénti alakulása 2016-2070 (EUROSTAT - EUROPOP 2015 alapján ${ }^{12}$, saját feldolgozás)

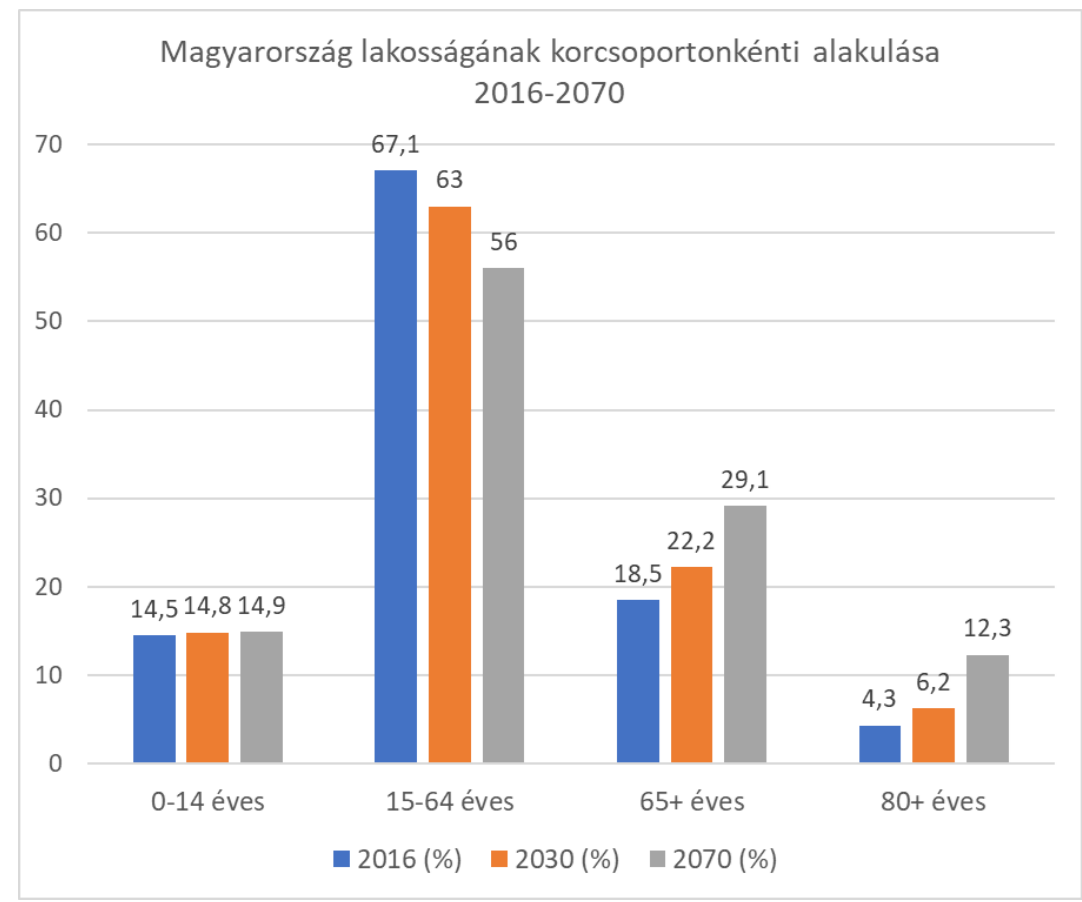

\footnotetext{
${ }^{12} \mathrm{https} / / / \mathrm{ec}$. europa.eu/eurostat/web/population-demography-migration-projections/populationprojectionsdata (Letöltve 2019. 02. 25.)
} 
Magyarország vonatkozásában is a fejlett országokra jellemző tendencia látható, ami szerint az aktív korúak arányának csökkenését az időskorúak arányának növekedése kíséri. A demencia vagy más neurodegeneratív kórképek, egyéb okból ápolást szükségessé tevő állapotok előfordulási gyakoriságának növekedése miatt külön figyelmet érdemel a 80 év felettiek arányának jelentős növekedése. Ennek a korosztálynak akár a 10\%-át is érintheti a demencia (Prince et al., 2013), és ez csak egyike a gondozásra okot adó kórképeknek.

\section{e. Informális ápolás}

Az informális ápolás annak a tevékenységnek a megnevezése, amikor nem szakértő, illetve a tevékenységet nem hivatásszerüen üző személy gondoskodik krónikus betegségben szenvedő vagy terminális állapotú családtagjáról, barátjáról (Van den Berg et al., 2004). Janet Heaton (1999) a fogalom eredetét keresve az 1970-es évekre vezeti vissza annak megjelenését, és számos folyamat következményeként lényegében egy filozófia-váltásra világít rá, miszerint a közösségben gondoskodás helyét a közösség által gondoskodás megközelítés vette át. Mindez következett elsődlegesen az egészségügyi intézmények müködési hatékonyságának éppen zajló növeléséből - a kórházi ágyak számának csökkentéséből -, melynek eredményeként szükségszerüen otthon kellett gondoskodni a betegekröl. Igaz, ezt a tevékenységet az ekkor fellendülő önkéntes és civil kezdeményezések, a fejlődő kommunikációs és technikai eszközök is segítették. Érdekes háttere ez a ma minden idős számára kívánatosként megjelölt „,ageing in place” (helyben megöregedni) mozgalomnak is, mely amellett, hogy valóban számos előnnyel rendelkezik, valójában szintén egy, az időskorú lakosság arányának és abszolút számának növekedéséből következő szükségszerüség a nem elegendő kapacitású formális ellátás miatt.

A fogalom megjelenésének kezdeti évtizedeiben tehát alapvetően önkéntesen, fizetség nélkül, szeretetből végzett tevékenységként (Heaton, 1999) írták le az informális ápolást. A tevékenység további kutatásai újabb dimenziókat tártak fel. A társadalmi fókuszú vizsgálatok során felismerték, hogy a családtag, barát, szomszéd gondozása nem feltétlenül önkéntesen vállalt tevékenység, hanem egyszerüen kényszer. Ekkor erősödtek fel azok a vélemények, melyek a gondozói lét negatív hatásait emelték ki (Zarit et al., 
1998; Pearlin et al., 1990; Kálmán et al., 2008). Ugyanakkor a tevékenység fontos társadalmi és gazdasági hatására hívták fel a figyelmet, miután a formális gondoskodás helyettesítő és kiegészítő formájaként magasztalták (Van den Berg et al., 2004). Az informális ápolás gazdasági tényezőként történő elismerése azért még váratott magára, hiszen Krol és munkatársainak 2015-ben megjelent összegző cikke címében még - ugyan provokáló - kérdésként szerepelt, hogy: „Számít az, hogy belevesszük az informális gondozást a gazdasági értékelésekbe?"13 (Krol et al., 2015, 123.o.). A szerzők válasza egyrészt igenlő, mivel a társadalmi jólét fontos meghatározójaként jelöli meg az informális ápolást. Másrészt a kutatása során áttekintett 100 releváns, költségelemzést tartalmazó publikáció alig negyede foglalkozott az informális ellátás költségeivel vagy egyéb hatásaival.

A közösség általi gondozás ideáját nagyjából az ezredforduló óta egy újabb fejlemény befolyásolja, ez pedig annak hangsúlyozása, hogy ez az ápolási tevékenység a nem tagadható nehézségek és terhek mellett pozitív hozadékokkal is jár (Rozario et al., 2004). A gondozói szerep pozitív aspektusainak hangsúlyozása, ezek felismerésének és fejlesztésének segítése pedig a gondozó családtag, barát, szomszéd, elfogadó/befogadó közösség jól-létének növekedéséhez vezet. Demenciával élőket gondozók esetén a pozitív hatások vizsgálata mostoha kutatási terület. Lloyd és munkatársai (2016) szisztematikus irodalomkutatást követően 14 kvalitatív kutatást elemezve igyekeztek a fogalmi keretet meghatározni. Összegzésük szerint a pozitív következmények két csoportra oszthatók: az egyikbe magából a gondozási tevékenységből származó „nyereségek” tartoznak, a másikba a gondozók és gondozottak közti dinamika következményei. A gondozói tevékenység például olyan pozitív hatásokat vált ki, mint a szereppel való elégedettség, a személyiség fejlődése, új tudás és kompetencia elsajátítása miatti öröm. A kapcsolatok javulásához vezethet a viszonzás vagy feltétel nélküli gondoskodás lehetőségének megélése, vagy a kötelességtudat, mely a szereppel való elégedettséggel társulva vezet egyfajta belső jutalmazáshoz. A gondozói tevékenységet végzőket támogató szolgáltatásoknak és közösségeknek ezeknek a kimeneteknek az elérését kell segíteniük személyre, gondozó-gondozott párra szabottan.

\footnotetext{
${ }^{13}$ „Does Including Informal Care in Economic Evaluations Matter?”
} 


\section{Publikációk bemutatása}

\subsection{Publikációk rövid ismertetése}

\subsubsection{Rendszertérképezés alkalmazása a hazai demenciastratégia}

megalapozásához

A Vezetéstudomány XLVIII. évfolyamának 12. számában megjelent publikációm (Fekete, 2017) egy kvalitatív kutatási technika alkalmazásának elméleti hátterét, kivitelezési tapasztalatait és eredményeit mutatja be. A részvételi rendszertérképezés (participatory systems mapping) megfelelö eszköznek tünt arra, hogy a - hazánkban még mind a mai napig megalkotásra váró - demenciastratégia megalkotásába bevonásra érdemes szereplők tudásmegosztását kezdeményezze. A központi, megoldásra váró problémaként a demenciával élők életminőségének javítását jelöltem meg. A cikkben egyrészt összegzem a módszer alkalmazásával kapcsolatos pozitív tapasztalatokat, másrészt bemutatom az eszköz alkalmazásának eredményét. A részvételi rendszertérképezés mind moderátori szemszögből, mind a résztvevők visszajelzései alapján megfelelőnek bizonyult a kitüzött cél megvalósításához. A résztvevök különösen a munka eredményének azonnali láthatóságát, a feltett kérdésre valódi válaszok születésének ritka élményét emelték ki, míg moderátori szempontból az erősen hierarchikus felépítésű egészségügyi, szociális és akadémiai rendszeren belüli és a hierarchiában eltérő szinten álló képviselői közötti valódi eszmecsere kialakulása volt igen pozitív tapasztalat.

A módszer szakpolitikai területen történő alkalmazhatóságát alátámasztja az eredmény, mivel a feltárt prioritások nagyrészt összecsengtek a stratégiaalkotásban előttünk járó országok programjaival. A komplex oksági diagramon négy csomópont tünt fel, úgymint a szakápolási, az orvosi ellátási és a hozzátartozói háttér, valamint az ismeret/információ témái. A kutatás után, a hozzátartozói önsegítő találkozókon szerzett tapasztalataim alapján is ezek a kritikus pontok a gondozásban részt vevő családtagok nézőpontjából is. Ahogy a publikációban is jeleztem, a módszert alkalmasnak gondolom arra, hogy hozzátartozókat, esetleg a tünetegyüttes enyhe formájában szenvedőket is bevonjon egy szakpolitikai koncepció kialakításába. 
3.2. Older New Zealanders in caregiving roles: Psychological functioning of caregivers of people living with dementia

Az elsőszerzős, publikációra 2017-ben elfogadott és online közzétett, nyomtatásban 2019-ben megjelent angolnyelvű publikációm (Fekete et al., 2019a) a demenciával élő családtagokat ápolók életminőségét befolyásoló tényezőket tárja fel egyedi megközelítéssel. A kutatás alapját az új-zélandi Massey University-n (Palmerston North) müködő Health and Ageing Research Team által koordinált Health, Work and Retirement Study adatbázisa képezte. Az adatbázis 2006 óta, kétévenkénti lekérdezéssel épül, és az 5 milliós népességű ország több mint 11 ezer lakosa vett részt a felmérésben az első 10 év alatt (HART, 2018) ${ }^{14}$.

A kutatás során módszertani megközelítésem személy-centrikus volt, melyhez a látens profilelemzés statisztikai eszközét alkalmaztuk. Az elméleti háttér alapján feltételeztük, hogy a gondozást végzők egy részénél a tevékenység negatív következményei vannak túlsúlyban, míg egy másik csoportnál a mérleg a pozitív hatások felé billen el, de nem zártuk ki köztes állapotú csoport(ok) azonosíthatóságát.

A pszichológiai müködést négy változó alapján definiáltuk, melyek:

- a mentális egészség (SF-12 alapján - Ware et al., 1998),

- a depresszió tünetei (nem azonos a depresszió klinikai diagnózisával, mérése CESD-10 skálával történt - Kohout et al., 1993),

- az életminőség (CASP-12 eszközzel mérve; Wiggins et al., 2008) és

- az élettel való elégedettség (Inglehart et al., 2004).

Látens profilelemzés során 2,3 és 4 csoport elkülönítését teszteltük, melyböl végül a három profil esetén adódott a legjobb eredmény. A három profilt végül optimális, szuboptimális és gyenge pszichológiai müködésü csoportként neveztük el az őket jellemző változók sztenderdizált értékei alapján.

\footnotetext{
${ }^{14}$ Health and Ageing Research Team. 2018. The New Zealand Health, Work and Retirement Longitudinal Study 2006-2016 Massey University http://www.massey.ac.nz/massey/fms/Colleges/College\%20of\%20Humanities\%20and\%20Social\%20Scie nces/Psychology/HART/publications/reports/NZHWR_10YearReport_20062016_LR.pdf?8010D8D175A2379138BF59C960D9025A (Letöltve: 2019.08.08.)
} 
Az érdekességeket kiemelve a demográfiai tényezők közül egyedül a gondozó életkora tekintetében lehetett összefüggést megállapítani a profilhoz tartozás vonatkozásában: a gyengén funkcionáló csoportba tartozó gondozók fiatalabbak voltak a másik két profilba soroltakhoz képest. Ezzel összecseng - ugyanakkor meglepő is -, hogy a rövidebb gondozási tapasztalat is a rosszul funkcionáló csoportba tartozókra volt jellemző. Ez egyértelmüen alátámasztja, hogy az informális gondozásnak lehet pozitív hozadéka, például az új tudás megszerzése, a személyiség gazdagodása révén (Rozario et al., 2004), valamint a megküzdési stratégiák - idő adta - kiépülési lehetősége is szerepet játszik ebben a kevésbé várt eredményben (Charlesworth et al., 2017; Greenwood és Habibi, 2014).

A profilhoz tartozásban az egyik legerősebb tényezőnek a társadalmi, közösségi támogatásra utaló változók bizonyultak, úgymint a kapcsolatrendszer kiterjedtsége, a magányosság érzése (itt fontos a magány érzelmi típusának és az izolációnak az elkülönítése), valamint a szociális ellátás elérhetősége.

A kutatás eredményeit összegezve tett javaslatokat a mai napig érvényesnek ítélem. Az azóta a gyakorlatban szerzett tapasztalataim alapján is úgy gondolom, hogy informális ápolást végző hozzátartozók adekvát segítéséhez az első lépésnek a profilba sorolásnak kellene lennie. Ahhoz, hogy a megfelelő támogatási módot tudjuk biztosítani, illetve a támogatási kapacitást hatékonyan tudjuk biztosítani, tudni kell egy adott hozzátartozóról, hogy - akár a fenti besorolás szerint - milyen funkcionális állapotban van, milyen rizikótényezőkkel kell számolni. Ahogy a publikációban is megjelöltük limitációként, a válaszadók állapotának változását nem követtük - aki a felmérés több hullámában is részt vett, annak az első válaszadásának az eredményeit vettük figyelembe a kutatásnál. Tekintettel arra, hogy a demencia egy progresszív kórkép, így a beteg állapota, mint elsődleges stresszor (Pearlin et al., 1990) jelentősen hozzájárulhat a hozzátartozói életminőség változásához. Bár jelen kutatás alapján az ápolás terhének, frekvenciájának mértéke nem mutatott összefüggést a profilhoz tartozással, arra csak longitudinális vizsgálatok adhatnak választ, hogy a betegség előrehaladtával, a tünetek súlyosbodásával, a gondozói terhek típusának változásával az informális ápolók mely tulajdonságai hogyan változnak. Ezáltal arra is lehetőség nyílna, hogy akár az egyes profilokra jellemző rizikófaktorokat azonosítsuk, és az informális ápoló a gondozói életútja alatt egy kidolgozott séma szerint, költséghatékony és eredményes közösségi támogatásban részesüljön. 


\subsection{Demencia és társadalmi fenntarthatóság}

Az Esély - Társadalom- és szakpolitikai folyóirat - 2019. évi 2. számában megjelent tanulmányomban (Fekete, 2019b) igyekeztem mindazt összegezni, amiért fontosnak tartom, hogy a demenciát ne csupán egy gyógyíthatatlan betegségnek tekintsék az egészségügyi és szociális területen dolgozók, vagy éppen az azon kívül tevékenykedők. Amíg ugyanis a demencia társadalmi problémát jelentő voltával bármely érintett terület szakemberei nincsenek tisztában, addig a többségi társadalomtól, a laikusoktól is aligha várható el, hogy a demenciával élőket és családjaikat a mindennapokban legalább toleranciájukkal támogassák.

A demencia előfordulása szoros összefüggést mutat a társadalom elöregedésével, így a tanulmányban arra is kitérek, hogy a hazai populáció tekintetében milyen mértékü közösségi teherre számíthatunk, hogyan csökken drasztikusan a felére pár évtized alatt a közösség „gondoskodási képessége”. Itt is kiemelem, hogy mennyire torz, hogy a családokra háruló egyre nagyobb mértékủ ápolási feladat nem jelenik meg értékként a gazdasági mutatószámokban. Így az sem ismert, hogy a gondoskodásban szerepet vállaló aktívkorú vagy éppen nyugellátásban részesülő családtagok a tevékenységükkel milyen értékü - jóléti - állami feladatot vállalnak át. Kritikát fogalmazok meg azzal kapcsolatban is, hogy a hazai egészségügyi és szociális ellátórendszer jelenleg nem felkészült az elöregedő populáció kiszolgálására. A rendszerek felépítésének és finanszírozásának is alkalmazkodnia kell a már javában zajló változásokhoz, tehát a szakpolitikai döntéseknek erre a területre is ki kell térniük.

A nemzetközi együttmüködések, érdekképviselet és szakpolitikai lépések bemutatásának célja elsődlegesen a jó példák ismertetése és annak hangsúlyozása, hogy a munkát már nem kell nulláról kezdeni, bár a helyi adottságok, szociokulturális és gazdasági körülmények figyelembevétele mindenképpen ajánlott - ehhez változatlanul jó eszköznek tartom a korábbi publikációban részletezett rendszertérképezés módszerét. 


\subsection{Publikációk teljes szövege}

\subsubsection{Rendszertérképezés alkalmazása a hazai demenciastratégia}

megalapozásához ${ }^{15}$

Összefoglaló:

A társadalom elöregedése fenntarthatósági kihívások elé állítja a nemzeteket. A várható élettartam növekedését a betegségben eltöltött évek számának emelkedése kíséri, mely azonban az egészségipari és ellátási fejlesztéseknek köszönhetően nem jár életminőség romlással. Speciális esetet jelent a demencia, melynek kialakulására az életkor növekedésével egyre nagyobb esély van. A demenciával élők száma tehát növekedni fog, és mivel tartós és fokozatosan növekvő mértékủ ápolási szükséglethez vezet a demencia, így kiemelt tényezője az időskori kiszolgáltatottságnak és az életminőség romlásának. A társadalmi fenntarthatóság ilyen jelentőségű kihívása esetén stratégiai tervezés, felkészülés, cselekvési program kidolgozása szükséges. Számos európai ország rendelkezik már a probléma megoldását célzó demencia stratégiával.

Jelen cikk egy kísérleti jelleggel alkalmazott kvalitatív módszert, a részvételi rendszertérképezést (participatory systems mapping) mutatja be, mint lehetséges eszközt egy demencia-stratégia megalkotásában. A rendszertérképezés és a részvétel módszertanok együttes alkalmazásának előnyei eddigi tapasztalatok alapján jól érvényesülnek szakpolitikai területeken, hosszabb távú tervek, rövidebb távú beavatkozási programok kidolgozásánál.

A demenciával élők életminőségének javítását középpontba állító, komplex oksági diagram készítésének vizuális eszközét alkalmazó, egymástól eltérő tudásbázisú résztvevők bevonásával szervezett együttgondolkodás tapasztalatai előremutatóak és a módszer további alkalmazására ösztönzőek. A kísérlet során sikerült prioritásként kezelhető kiemelt témákat, problémákat azonosítani, mindemellett a résztvevők

\footnotetext{
${ }^{15}$ BCE GDI kérése alapján a 3.2.1 fejezet a következő publikáció szó szerinti szövegét tartalmazza: Fekete, M. (2017). Rendszertérképezés alkalmazása a hazai demenciastratégia megalapozásához. Vezetéstudomány, 48 (12), 24-32.
} 
megtapasztalták a részvétellel járó pozitív hatásokat, valamint érvényesült az ábrázolás kommunikáció támogató célja.

Kulcsszavak: rendszertérképezés, részvétel, társadalom elöregedése, demencia, stratégia

Bevezetés

Hazánk különösen érintett a társadalom elöregedésének világszinten tapasztalható, szerteágazó hatásokkal járó folyamatában. Magyarországra vonatkozó elörejelzések szerint a populáció életkor szerinti összetétele 2060-ra drámaian meg fog változni. Az Eurostat adatai alapján (Eurostat, 2014) ${ }^{16}$ Magyarországon 2013-hoz képest 2060-ra a 65 év felettiek aránya 12\%-kal, a 80 év felettiek aránya közel 16\%-kal nő, ugyanakkor az aktív korúak (15-64 év közöttiek) aránya 12\%-kal csökken, míg a gyermekkorúak aránya lényegében változatlan marad. Plasztikusabban ugyanez kifejezve: míg 2013-ban egyetlen 80 év feletti mögött 16 aktív korú sorakozott fel, addig 2060-ban már nem egészen 5 fó áll majd helyt. Ez a demográfiai folyamat, melyet a szakirodalom „elöregedés” (ageing/aging) névvel illet, fenntarthatósági kihívások elé állítja a nemzeteket, mivel új megoldások szükségesek többek között a nyugdíj-, az egészségügyi, valamint a szociális ellátás rendszerében. A kihívások egyik - ma hazánkban még fel nem ismert jelentőségü - előidézője a demencia terjedése.

A várható élettartam növekedését a logika és a tapasztalat alapján a betegségben eltöltött évek számának emelkedése kíséri, mindamellett, hogy a betegségek kialakulása többnyire multifaktoriális. Az egészségipari és ellátási fejlesztéseknek köszönhetően a világ fejlett országaiban az idősebb kort megérőknek sem kell számolnia a funkcionális korlátozottság növekedésével, az életminőség romlásával annak ellenére, hogy a krónikus - például szív-érrendszeri, légúti vagy anyagcsere - betegségek, valamint a rosszindulatú daganatos megbetegedések előfordulása is nőni fog (Christensen at al., 2009). Speciális esetet képez a demencia, mivel elsődlegesen éppen bizonyos képességek romlása, funkcionális korlátozottság képezik a tünetegyüttes összetevőit, tehát azok nem következményként, hanem elsődleges betegségjelzőként lépnek fel.

\footnotetext{
${ }^{16}$ Eurostat, 2014; http://appsso.eurostat.ec.europa.eu/nui/show.do?dataset=proj_13npms\&lang=en
} 
A demencia a kognitív, gondolkodási funkciók hanyatlásával járó folyamat, melynek legszembeötlőbb jele a memóriafunkció elvesztése, az életkorral összefüggő kórkép. Ma már elavult fogalmak, de korábban ezt a kóros folyamatot ,időskori elbutulás” vagy „szenilitás” megnevezésekkel illették, mely nomenklatúra azt is kifejezte, hogy az állapotra az öregedés természetes részeként tekintettek. Ez a téves szemlélet is szerepet játszhatott abban, hogy miért nem irányult eddig kellő figyelem a probléma mértékére.

A demencia többféle kórfolyamat eredményeként is kialakulhat, döntő részben azonban nem gyógyítható, a mai terápiás lehetőségektől legfeljebb a tünetek mérséklése és a folyamat előrehaladásának lassítása remélhető. A tünetegyüttes előrehaladásával a betegek kiszolgáltatottsága fokozatosan nő, végül az önálló életvitel folytatására is képtelenné válnak, és akár 10 évig is ápolásra szorulnak (Aguero-Torres at al., 1998).

Nemzetközi becslések (EUROCODE Project: Dementia in Europe Yearbook 2006) a világszintü prevalencia adatokat alapul véve Magyarországon legalább 110-130 ezer demenciával élő beteget feltételeznek, akiknek csak a töredékét azonosítja, gondozza és kezeli a hazai egészségügyi és szociális ellátás rendszere. Más szakértői vélemény akár 2-300 ezer ember érintettségét is elképzelhetőnek tartja, és a 85 év feletti korosztályban 30\%-ra becsüli a demenciával élők arányát (Kovács, 2016). Tekintve a társadalom elöregedésének tendenciáját, a demenciával élők számának jelentős növekedésével kell számolnunk, és időben fel kell készülni ennek a tehernek a kezelésére. A társadalmi fenntarthatóság ilyen jelentőségü kihívása esetén joggal vetődik fel a kérdés: hogyan érdemes stratégialag tervezni, kezelni és felkészülni a valószínűsíthetően várható helyzetre.

Jelen cikk bemutatja azt a kísérleti jelleggel alkalmazott kvalitatív módszert, a részvételi rendszertérképezést (participatory systems mapping), ami egyik eszköze lehet a demencia-stratégia alkotási folyamatnak. A rendszertérképezés módszere alkalmas sokféle érintett szereplő bevonására és együttgondolkodásának strukturálására. A részvételiség biztosítja a sokféle szempont, tudás és tapasztalat egy színtéren történő megjelenését. A közösen létrehozott oksági struktúra térképszerüen megjelenítve akár azonnali visszajelzést ad a résztvevőknek közös alkotásuk fő elemeiről, az elemek közötti kapcsolatokról, s az intervenció hatásosnak tetsző pontjairól. 
Háttér - a demencia társadalmi jelentősége

A magyar populáció előrejelzett öregedési tendenciája miatt hazánkban a demencia, a gondolkodási funkció előrehaladott zavara hamarosan komoly össztársadalmi problémát fog jelenteni a tünetcsoporttal érintettek (betegek) tömege miatt (EUROCODE Project: Dementia in Europe Yearbook 2006). A probléma komplexitása részben a betegség jellemzőiből következik, így célszerü ennek rövid áttekintése, melyben a számos, helyenként egymásnak ellentmondó orvosszakmai forrás mellett már konszenzuson alapuló szakértői véleményeket összegző tanulmányra is támaszkodhatunk (Annear, 2015). A demencia, Alzheimer-demencia, Alzheimer-kór kifejezések hallatán legtöbbeknek a memóriazavar, emlékezőképesség elvesztése, mint társuló fogalmak jutnak eszébe, ugyanakkor a gondolkodási funkció romlása nem csupán a memória, az emlékezőképesség területén okoz problémát, hanem egy sor egyéb megnyilvánulása van. Így a tünetek közé tartozhat a figyelem fenntartásának vagy a döntésképességnek az elvesztése, a tervezés, a szervezés, a problémamegoldás képességének zavara, az ítélőképesség bizonytalanná válása, vagy akár a kifejezőképesség, a beszéd nehezítettsége. Mindezeket sorra véve azonnal több olyan mindennapi élethelyzetet tudunk felidézni, melyben egy demenciával élő segítségre, támogatásra szorul. Meg kell említeni, hogy a demencia nem kizárólag az időseket érintő kórkép, hanem aktív korú, akár 50 éves embereknél is kialakulhat igen súlyos formája. Elsődleges forma esetén a minél koraibb felismerés, a gyakran más pszichiátriai betegség - leginkább depresszió tüneteit mutató beteg szakemberhez irányítása lenne a legfontosabb lépés, míg másodlagosan, a közvélemény által is ismerten népbetegség szintjén nyilvántartott agyi érkatasztrófa (másnéven sztrók) bekövetkezése után a megelőzésre kellene nagyobb figyelmet fordítani (Kling, 2013).

Amikor egy probléma kezelését célzó cselekvési terv, stratégia felvázolására készülünk, fontos azonosítani az elsődlegesen érintetteket, hisz a leghatékonyabb beavatkozást ezt a kört érintően tehetjük meg. Emellett, ha a részvételre, mint tudásintegrációs módszertani lehetőségre, tekintünk, akkor az elsődlegesen érintettek bevonása is mérlegelendő. Hangsúlyozandó különlegessége a demenciának, hogy elsődleges érintettnek nemcsak maga a demenciával élő személy tekintendő, hanem az őt gondozó családtag vagy más önkéntes segítő is, hiszen a tünetegyüttes - nem véletlenül részletezett - összetettségéből adódóan a diagnózis felállításának pillanatában azonnal egy támogató, majd később aktív, folyamatos ápolást biztosító személyt kell a beteg állandó társaként számba venni. E társ 
a legtöbb esetben egy családtag, aki kényszerüség okán, vagy ritkább, de szerencsésebb esetben önként választva került ebbe a szerepkörbe. Ez az informális ápolói, gondozói szerep több megközelítésből is a kutatói érdeklődés fókuszában áll (Etters et al., 2008; Fonareva et al., 2014; Krol et al, 2015): az ápolást végző személy pszichológiai jóllététől, a nála fellépő testi betegségeken át a tevékenységnek a közgazdasági vonatkozásáig, több téma is egy-egy kutatás középpontjába állítható

Érintett ugyanakkor a problémában a teljes szociális- és egészségügyi ellátó hálózat, valamint a társadalom egésze, mivel részt kell vállalnia a közvetlenül érintettek összetett és jelentős terheinek mérséklésében, melyre elsődlegesen anyagi vonatkozásban, nemzetgazdasági megközelítésben adódik lehetősége a költségvetésből fedezett szociális és egyészségügyi kiadások forrásainak adók és járulékok formájában történő megfizetése révén. Az Egészségügyi Világszervezettel (World Health Organization, WHO) együttmüködésben dolgozó, világszinten több mint 80 tagot tömörítő Alzheimer's Disease International nevü szervezet 2009 óta jelenteti meg World Alzheimer Report címü kiadványát, melynek először a 2010-ben kiadott száma foglalkozott kiemelten a gazdasági hatásokkal, majd 2015-ben tértek vissza e témára, és az eltelt öt évben a társadalmi költségek növekedését 35\%-ra tették. A három fö költségtényező közti megoszlás viszonylag állandónak mutatkozik: a direkt egészségügyi költségek tesznek ki 20\%-ot, míg a szociális ellátás költségei és az informális ellátás költségei egyenlően körülbelül 40-40\%-ot képviselnek. A költségek összetettsége is utal a demenciához kapcsolódó problémakör komplexitására.

Európai demencia stratégiák - miértek és hogyanok

Az Európa Tanács 2002-ben, az idősödő társadalom jelentette szociálpolitikai kihívásokkal kapcsolatban megfogalmazott ajánlása ${ }^{17}$ a demenciát is megemlíti azok között a krónikus betegségek, állapotok között, melyek az időskorúak fokozott kiszolgáltatottságához és életminőségük romlásához vezet. A WHO 2008-ban emelte a demenciát a prioritást élvező kórképek közé, majd 2013-ban a gyógyszerfejlesztés világszintü koordinációját célzó kiadványában (WHO, 2013. Priority Medicines for Europe and the World - A Public Health Approach to Innovation) került azon 24

\footnotetext{
${ }^{17}$ Doc. 9615,31 october 2002, Challenges of social policy in our ageing societies - Report: http://assembly.coe.int/nw/xml/XRef/X2H-Xref-ViewHTML.asp?FileID=9911\&lang=EN
} 
kórállapot, betegség listájára, melyek olyan jelentős társadalmi terhet okoznak, hogy kiemelkedő fontosságú a terápiás lehetőségek terén fejlődés elérése.

Tekintettel a demencia által képviselt probléma összetettségére és mértékére, kezelésére nemzeti stratégia kell. Ezt elsőként Franciaország ismerte fel, ahol 2001-ben fogadták el az első cselekvési tervet, és ma már a 4. program fut. Mint minden, a szociális és egészségügyi ellátó rendszerre jelentős mértékben építő programnál, egyediséget követel, hogy a cselekvési tervet a fennálló vagy reálisan kialakítható ellátási rendszerhez kell igazítani - legalább az első lépéseknél. Emellett a nemzeti sajátság másik forrását a szociokulturális hagyományok adják, melyek nem hagyhatók figyelmen kívül különösen egy ilyen területen, ahol a családi és a legtágabb értelmü társadalmi kapcsolatok szintjén is hatást gyakorló beavatkozásra van szükség.

Mára 21 európai tagállam rendelkezik demencia stratégiával. 2016-ban négy ország Cseh Köztársaság, Görögország, Szlovénia, Spanyolország - is eljutott a stratégiája kormányzati kihirdetéséig a több éves előkészítő folyamat eredményeként. Az egészségügyi- és szociális területet egyaránt érintő cselekvési tervek a legtöbb esetben egy önszerveződő szakértői csoport kezdeményezésére születnek meg, és a kormányzati szervek különböző mértékü bevonása, beavatkozása után a kormányok által meghirdetett programként lépnek a megvalósulás útjára. A szakértőket rendszerint az adott ország Alzheimer-kórral és egyéb demenciákkal élőket képviselő, demenciával élőket gondozó személyeket és intézményeket tömörítő szervezete vagy szervezetei delegálják, illetve hívják fel az együttes munkára. Az első lépés rendszerint egy fórum kialakítása, ahol a szakértők a tudásukat megoszthatják. Ez valahol egy tanulmánykötet, összegző riport megalkotása, máshol egy konferencia, szimpózium szervezése keretében történt. Ezt követően kerül sor általában az elsődlegesen kitűzendő célok, a végrehajtandó feladatok megfogalmazására. A szakértők által elkészített stratégiai dokumentum munkaverzióját rendszerint nyilvánosságra hozzák, vitára bocsátják, és az arra születő reflexiók alapján készül el az a végleges verzió, melyet államirányítási szinten hirdetnek ki, fogadnak el. A cselekvési tervek rendszerint 3-5 évre szabnak feladatokat, így a stratégiaalkotásban élen járók már többedik programjukat hirdetik ki, melyek az előzőekben megfogalmazott célok megvalósulásának érékelésén alapulnak. Fontos tehát, hogy a meghatározott prioritások mérhetőek, értékelhetőek legyenek. (Ábra 1.) 


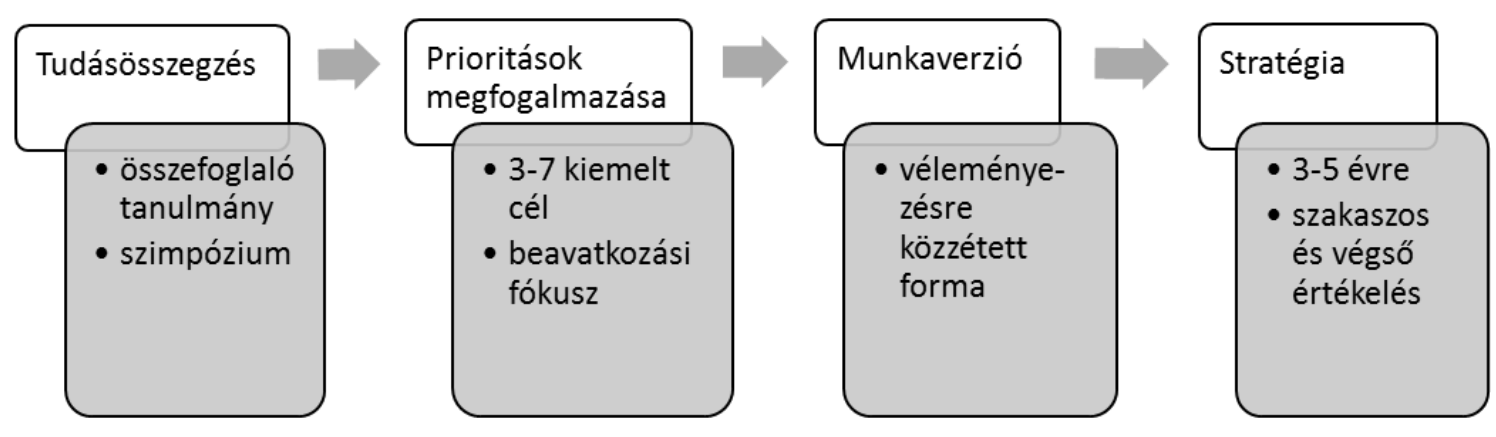

Hazánk nem rendelkezik stratégiával, még vitára bocsátott munkaverzióval sem, így lemaradásunk években mérhető. A hazai szemlélet formálásának szükségességét mutatja, hogy a demencia egyre nagyobb tömegeket érintő és az egészségügyi- és szociális ellátó rendszerre egyre nagyobb terhet rovó tényezőként sem az egészségügyi (Egészséges Magyarország 2014-2020) ${ }^{18}$, sem a szociális terület általános stratégiájában (Nemzeti Szociálpolitikai Koncepció 2011-2020; 2011) ${ }^{19}$ nem kerül említésre, szemben ennél jóval kisebb társadalmi és költségvetési jelentőségü kórképekkel.

Módszertan - kvalitatív megközelítés alkalmazása a tudásösszegzéshez

A rendszertérképezés és a részvétel, mint módszertanok, összekapcsolt alkalmazása viszonylag friss megközelítés (Király et al. 2015). Jellemzően szakpolitikai területeken tud érvényesülni a metódusok együttes alkalmazásában rejlö számos előny, így stratégiafejlesztésnél, hosszabb távú tervek megfogalmazásánál, vagy rövidebb távú beavatkozási programok kidolgozásánál érdemes a kombinált módszerhez fordulni. A

\footnotetext{
18 http://www.enkk.hu/index.php/hun/kepzesi-kozpont/233-egeszseges-magyarorszag-2014-2020 (letöltve 2016.12.01.)

${ }^{19}$ Nemzeti Szociálpolitikai Koncepció 2011-2020; 2011, Czibere Károly, Sziklai István, Mester Dániel, Dr. Vörös Gyula, Sidlovics Ferenc, Skultéti József, Beszterczey András
} 
rendszertérképezés a rendszerdinamikai megközelítés alapján a negatív és pozitív visszacsatolások, hurkok ábrázolása útján feltárja azokat a lehetséges beavatkozási pontokat, melyek bármely probléma megoldásához szükséges döntések célpontjai lehetnek (Vennix, 1996). Ahogy az a módszer megalkotójának, J. W. Forresternek az életmüvében is követhető, mérnöki technológiafejlesztés vezetett egy vezetéselméleti vívmány megalkotásához az 50-es évek végén, mely az elmúlt évtizedek alatt egyre szélesebb körü felhasználásra került (Lane, 2007). Miután nyilvánvalóvá vált, hogy a mérnöki után a menedzsment tudományterületen is müködőképes a rendszerdinamikai modellezés, a vállalati után a komplex társadalmi rendszerek összefüggéseinek tisztázására is alkalmasnak tünt. Mint ilyet, először egy város működési dinamikájának feltérképezése során használta maga Forrester, majd 1970-ben felkérték a világ globális fejlődésének rendszerdinamikai elemzésére, melynek során a fejlődés fenntarthatóságának tényezőit tárta fel a módszerrel. Ezen munka folytatásaként került sor a módszer alkalmazására a természeti környezettel kapcsolatos rendszerek kutatásában. Később számos egyéb tudományterületen alkalmazták ezt az elemzési módszert. Az egészségtudományok területén is található, ugyan csekély számú példa. Alkalmasnak találták közegészségügyi problémák - melynek a demencia is tekinthető feltárására, mivel transzdiszciplináris szemléletre van szükség a biológiai, szervezeti és politikai elvek egyidejű érvényesítése érdekében, és a módszer megfelelő eszköz ezen elvárás biztosításához (Leischow, 2006).

A részvétel biztosításának szükségessége a társadalompolitikai döntésekben már az évezred elején elvárásként került megfogalmazásra annak pontos tisztázatlansága mellett, hogy mit is kell részvétel alatt érteni (Bishop, 2002). A kormányzat és a döntéshozók gyakran egyfajta szürőn keresztül észlelik csak a mindennapi történéseket, a társadalmi rendszerek müködését, így azok feltérképezése nem képzelhető el a valódi érintettek bevonása nélkül. A bevonás különböző szintű lehet: az információ-forrásként való felhasználástól a döntéshozatalba való bevonásig terjedhet.

Ezen „ajánlások” jelentették a kiindulópontját a cikkben bemutatásra kerülő, kísérleti jelleggel végzett, stratégia megalapozó együttgondolkodásnak. A kísérlet több szempontból egyedi: egészség- és szociálpolitikai területen hazánkban a stratégiaalkotás nem rendelkezik nagy hagyományokkal, és még kevésbé jellemző a professzionális vagy laikus célközönség bevonása egy problémafelmérésbe vagy cselekvési terv 
megalkotásába. E szakterületeken még nemzetközi viszonylatban is nehéz példákat találni az érintettek bevonásával zajló, rendszertérképezésen alapuló programalkotásra.

Megismerve a kombinált módszertan hazai gyakorlatban is igazolt előnyeit (Király, 2014), született meg a döntés a kutatás kivitelezésének módjáról. Először is a módszer feltáró jellegü, és az oksági összefüggések ábrázolása különösen támogatja a probléma mélyebb megértését. Másrészt az együttgondolkodás folyamata során úgynevezett változókra és az azok közti összefüggésekre koncentrál a diskurzus, mely semleges kommunikációt tesz lehetővé, hiszen nem ideológiákat, komplex véleményeket kell megfogalmazni, hanem konkrét tényezőkről és azok közti kapcsolatokról szól az eszmecsere. Mindez azt is elősegíti, hogy egymástól akár jelentősen eltérő tudásbázisú, más fókuszú vagy szintű tudással rendelkező résztvevők képesek legyenek együtt dolgozni. Harmadrészt, mint általában a vizuális technikák, a gondolkodás, a tudásösszegzés eredményének képi megjelenítése megkönnyíti a dokumentációt, akár a folyamat szakaszait akarjuk követni, akár a végeredményt kívánjuk rögzíteni, elemezni. Az ábrázolást és elemzést szabadon elérhető szoftverek is segítik. Szintén fontos, és a módszer kiválasztásának szempontjából talán elsődleges volt a módszer azon jellemzője, hogy könnyen tanulható és tanítható, azaz átadható a technika.

Mind a négy kiemelt alapvető módszertani előny hozzájárult ahhoz, hogy a demencia stratégia készítésének megalapozását célzó tudásszintézishez részvételi rendszerdinamikai eszközhöz nyúljunk kísérletképpen. A módszer további előnyeinek számbavételénél érdemes a részvétel és rendszertérképezés elemeket egy időre szétválasztani. A részvétel biztosításának előnyei, különösképpen hazánkban, még mindig hangsúlyozásra szorulnak (Király, 2014). Talán a legkönnyebben elfogadott érv mellette, hogy több embernek több a tudása, minden egyes szereplö potenciálisan valamit hozzáad a kollektív tudáshoz. Fontos azonban kicsit e mögé is nézni. Maga a részvétel biztosítása egy pszichológiai értelemben vett szükségletkielégítő módszer, és ezáltal a résztvevő jóllétének javításához is hozzájárul, valamint őt motiváltabbá teszi. Ha a döntéshozó számára biztosított a részvétel, akkor tőle megalapozottabb, jobb döntés remélhető a részvétele útján hozzá eljutó több információ révén. A részvétel különböző pozícióban lévő szereplők számára találkozási, közvetlen kapcsolati lehetőséget is biztosít, mely már meglévő vagy potenciálisan kialakuló konfliktusok kezelésére, ideális esetben megelőzésére is lehetőséget ad. A társadalom egészét tekintve a „demokratikus/demokrácia deficit” csökkentésének bármely módja, így ez az eszköz is 
haszonnal kecsegtet. A hétköznapi, egy adott problémával minden nap szembesülö ember, és döntései által közvetetten az ő életét mindennapi szinten befolyásoló döntéshozó eltávolodása mára jelentős probléma. A részvétel biztosítása - ha nem is a társadalmi spektrum két legszélső pontjának találkozását, de legalább - köztes szereplők közvetlen kommunikációját tudja biztosítani. Kiemelt jelentőségű a résztvevők személyének helyes megválasztása, ugyanakkor a részvétel módja, formája is, hogy a résztvevők kellő szabadságot élvezzenek a folyamat során. A téves elvárások elkerülése érdekében a részvétel kimenetét, a folyamat végső célját is célszerü előre tisztázni a szereplőkkel, hogy se későbbi csalódás, se menet közbeni visszafogott motiváltság ne alakuljon ki.

A rendszertérképezés egyik kritikus eleme az úgynevezett belső nézőpont alkalmazása (Richardson, 2011). Eszerint a vizsgált rendszer müködését, viselkedését befolyásoló tényezők közül azok képezik a modell szerves részét, melyek szerepet játszanak annak dinamikájában, visszacsatolás, egymásra tett hatásokból képzett zárt hurkok képzése révén. Ebből következően alkalmazása az interdiszciplináris együttmüködés felé tett lépésnek is tekinthető kutatási aspektusból, mivel ábrázolja az eltérő szakterületekhez tartozó tényezők egymásra hatását a vizsgált rendszeren belül, és ha mindezt a részvétellel kombináljuk, akkor elérhetjük a transzdiszciplinaritás szintjét, azaz amikor nem csupán arra van lehetőség, hogy a különböző szakterületek eltérő szemlélete felszínre kerüljön, hanem hogy az eltérő nézőpontok és tudástípusok mintegy kölcsönhatásba lépve, egymást formálják is. Ez tekinthető egy fajta közös tanulási folyamatnak is, hiszen mindenkinek gazdagodik a meglévő ismeretanyaga és formálódik a szemlélete. Mivel a tárgyalandó problémáról senkinek nincs meg az átfogó tudása, így elengedhetetlen az egyéni szereplők tudás- és szemléletmozaikjainak összeillesztése. Erre kínál megfelelő lehetőséget a részvételi rendszertérképezés, melynek célja, hogy a tudás kollektivizálása után, a felvázolt összefüggésrendszer alapján beavatkozási pontokat azonosítsanak a résztvevők, és akár különböző távú cselekvési programokat építsenek fel.

A módszer korlátait szintén meg kell említeni, ugyanis - saját tapasztalataink alapján is - a résztvevők jelentősen befolyásolni tudják a kimenetet. Bár a kommunikációt az eltérő tudásszintű résztvevők között valóban jelentősen megkönnyíti az ábrázolási technika, és a változókra épített gondolatfüzés valóban leegyszerüsíti a komplexitást, de a rendszertérképezés jelentőségének felismerése egyfajta elvontabb gondolkodást, magasabb szellemi teljesítményt igényel, és ezáltal a résztvevők egy részének szellemi 
fölénye akár eltolódást eredményezhet még elemszintű megközelítés esetén is. Hasonló okra vezethető vissza, hogy a koncentrált gondolkodás nem azonos mértékü kifáradást fog eredményezni az inkább kutató, elméleti szakemberek és a gyakorlati területen dolgozó szakemberek között. A moderátornak így fontos feladat jut a munkafolyamat megfelelő felépítésében, és az eszmecsere során a kiegyenlített megnyilvánulási lehetőségek biztosításában.

Tudásösszegző céllal folytatott részvételi rendszerdinamikai modellezés - szervezéstől a végrehajtásig

A fenti elméleti alapvetések mentén kezdődött az eszmecsere szervezése, melynek központi eleme volt egy olyan szervezet, amelynek szerepe a hazai demencia-ügy képviseletében azóta hivatalosan is igazolást nyert. A Szociális Klaszter Egyesület ${ }^{20}$, mely ápolóotthonokat, idősápolást végző intézményeket, illetve a területhez bármely szempontból kötődő egyéni tagokat tömörít, 2016 októberében nyert felvételt az Alzheimer Europe ${ }^{21}$ ernyőszervezetbe. A szervezet 2016 novemberi jelentése alapján 34 ország 39 szervezetét, mint teljes jogú tagot, tömörít, és további 4 ország 4 szervezete köztük Magyarországról elsőként a Szociális Klaszter - mint leendő tag szerepel a partnerek között.

A Szociális Klaszter az idősellátásban és ezzel együtt a demenciával élők ellátásában érintett intézmények és szakemberek közti kommunikáció támogatásában, érdekképviseletében évtizedes múlttal rendelkező szervezet. Ez garanciát jelentett arra, hogy a rajtuk keresztül továbbított meghívás az együttgondolkodásra jó fogadtatásra talál. Az egyesület kapcsolatrendszere egyúttal meg is határozta a bevonandó szereplők körét, ami részben limitációt jelentett, ugyanakkor érvényesíteni sikerült a multilateralitást. (Ábra 2.) A legfőbb limitáció az üzleti szféra kimaradása, melynek azonban jelenleg nincs jelentős szerepe a demenciával élők ellátásában sem az egészségügyi, sem a szociális területen. Érdemes lenne ugyanakkor a bevonása a jelenleg ezen a téren nem tevékenykedő magánellátóknak, mivel más területen szerzett tapasztalataik hasznosak

\footnotetext{
${ }^{20}$ Köszönetnyilvánítás: A szerző ezúton fejezi ki köszönetét az egyesület vezetőjének, Dr. Egervári Ágnesnek, és munkatársának, Dr. Vajda Norbertnek a kutatás megvalósításához nyújtott segítségükért, támogató és ösztönző javaslataikért, valamint minden résztvevőnek az együttmüködésért.

${ }^{21}$ http://alzheimer-europe.org/Alzheimer-Europe/Who-we-are/Our-members (letöltve: 2016.12.12.)
} 
lehetnek. A Szociális Klaszter maga az egyetlen civilként megjelenő résztvevő ebben a körben, melynek képviselői egyúttal az intézményfenntartókat (mint egyházi szervezet) és intézmény müködtetőket is képviseli, így megjelenésükben nem a civil megközelítés a hangsúlyos. A valódi civil képviseletet a kis számban már hazánkban is létező hozzátartozói támogatói fórumok (pl. Alzheimer Cafe) (Morrissey et al., 2006) részvétele jelentené.

Ábra 2. - A demencia stratégia megalapozásához végzett rendszertérképezésbe bevont szereplök
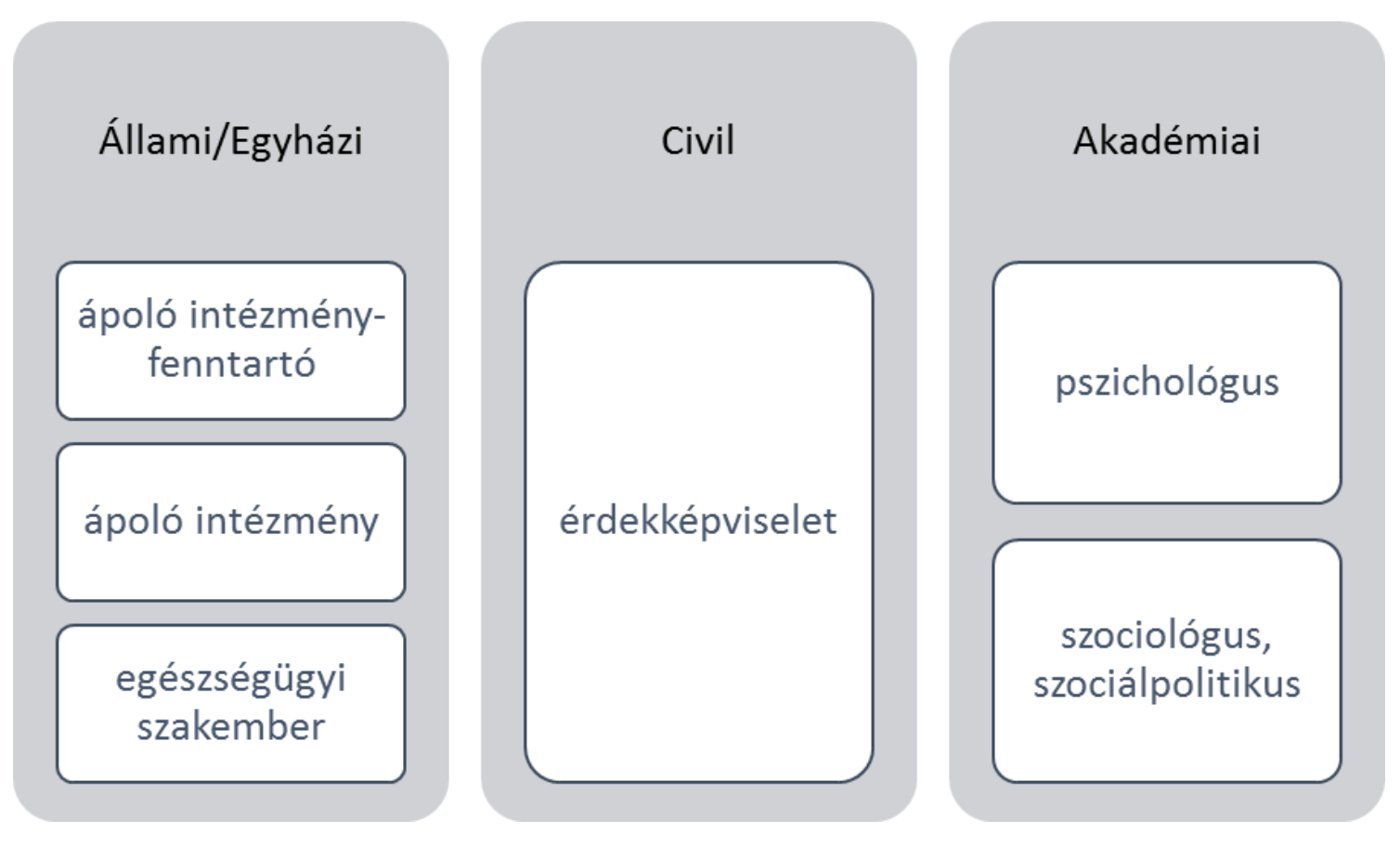

A civil szervezet vezetői tettek név szerinti javaslatot a meghívandó szereplőkre azután, hogy közösen meghatároztuk, hogy milyen terület képviselöit hívjuk meg a beszélgetésre. Az elsődleges cél az volt, hogy gyakorlati és elméleti szakembereket egyaránt bevonjunk a gondolkodási folyamatba. Ebből viszont következik, hogy tudományos előmenetellel rendelkező szereplőktől középszintü végzettségűekig terjedhet a skála. Emiatt is volt kiemelt hangsúly az ábrakészítésen, mivel alapoztunk annak a kommunikációt megkönnyítő szerepére. A gyakorlati területet képviselő szakemberek között ápolást végző intézmény vezetőjét, egyházi intézményfenntartó vezetőt, demenciával élőket is gondozó, kezelő neurológus szakorvost, az alapellátást képviselő háziorvost, a szociális ellátás terén tapasztalattal rendelkező szociológust, míg elméleti területről a pszichológia 
és a szociológia területén kutató szakembereket hívtunk meg. Kiindulásként körülbelül tíz résztvevő megnyerését határoztuk meg. Minden meghívottat személyesen ismert a Szociális Klaszter felkérést kiküldő képviselője, melynek feltehetően szerepe volt abban, hogy igen jó arányú volt a meghívás elfogadása. A moderátorral ${ }^{22}$ együtt végül 12 fö vett részt a kísérletben.

A demenciával élök és az őket ápolók segítését célzó demencia stratégiára nem pusztán a nemzetközi elvárások miatt van szükség, hanem mivel az ellátórendszerek nagy mértékü leterhelése és a rossz hatásfokú természetbeni vagy pénzbeli állami gondoskodás, támogatás az egész társadalomra vonatkozóan jelentős hatású. A probléma komplexitása miatt különösen fontos az interdiszciplináris megközelítés, melynek során a saját koncepciók egyfajta kombinálása, hosszabb együttmüködés során egymás átformálása, a társterületek szempontjainak, látásmódjának elfogadásával egy közös koncepció felállítása valósulhat meg. A stratégia alkotás előkészítő lépésének tekinthető a szempontok összegyüjtése, mivel ez ahhoz is támpontot ad, hogy az iteratív folyamat során mely újabb és újabb szakterületek bevonása szükséges a legátfogóbb, minden tényezőre kiterjedő, konszenzuson alapuló és megvalósítható, valamint fenntartható program megalkotásához.

Ahogy azt a már kész európai nemzeti demencia stratégiáknál rendszerint láthattuk, a demencia, mint fó téma mellett egy vagy néhány kiemelt szempont köré épül fel egy-egy cselekvési terv. Prioritások meghatározása esetén a teljes program megvalósulásának lépései jobban követhetők, sikeressége jobban mérhető, ugyanakkor nem zárja ki, hogy másodlagos célokra is jusson figyelem és erőforrás. Jellemző, nem ritkán elsődlegesként vagy azok között meghatározott cél a demenciával élők diagnózishoz jutásának javítása, azaz a betegségnek a felismerése, hiszen azonosított érintettek nélkül mit sem ér egy program. Az új esetek száma, a felismert betegek között a korai stádiumban lévők arányának változása mérhető, követhető. Kiemelt célok között szerepel gyakran az ellátórendszer szükséges spektrumának felmérése és megteremtése, valamint annak müködési hatékonyságát leginkább jellemző paraméterénként a demenciával élők és hozzátartozóik életminőségének javítása.

\footnotetext{
${ }^{22}$ A moderátori feladatkört a cikk szerzője, a kísérlet kiötlője látta el. A szerző orvosszakértői tevékenysége során találkozik demenciával élő aktív korú betegekkel és ápoló hozzátartozóikkal, gondozóikkal, valamint tagként segíti a Szociális Klaszter Egyesület munkáját.
} 
Alakuló munkacsoportunk követve ezt a mintát, úgy döntött, hogy a mind a majdani stratégia-alkotás, mind az együttgondolkodás céljából megfelelő vezérgondolat, központi cél a demenciával élök életminőségének javitása.

A folyamat gyorsítása és a módszertan újdonsága miatt várható kezdeti nehézkesség áthidalása érdekében egy, a vezérgondolat köré épülő kezdeti fogalomtárat, a rendszertérképbe később beépíthető változó gyüjteményt állított össze a szerző a résztvevők bevonásában segédkező egyesületi munkatársak közremüködésével még a közös munka előtt. Ehhez a forrást egyrészt szintén a demenciával élők, családtagjaik és ápolóik életminőségének javítását központba állító máltai demencia-stratégia jelentette, másrészt a 2015 folyamán, Európai Uniós támogatás révén zajlott INterprofesszionális Demencia Alapprogram (INDA) ${ }^{23}$ adta. Az INDA programot a Római Katolikus Egyházi Szeretetszolgálat a Szociális Klaszter Egyesülettel együttmüködve dolgozta ki és hajtotta végre, alapozva mindezt a Szeretetszolgálat több mint hat évtizedes, az intézményi idősellátásban szerzett fenntartói, és az Egyesület tagintézményeinek gyakorlati gondozói tapasztalatára. E két forrásból összesen 45 , a demenciával élők életminőségéhez köthető változót fogalmazott meg a moderátor, melyet a résztvevők az elméleti alapozás, a módszertant röviden ismertető bevezető előadás után ismerhettek meg. A résztvevőknek a listán a megítélésük szerint legfontosabb, tetszőleges számú fogalmat kellett megjelölniük, majd a moderátor összegezte ezeket. A leggyakrabban (legalább 5 résztvevő által) megjelölt tényezőket külön felírta, már az összefüggések megjelenítésére alkalmas módon (post-it), így az ábrázolás folyamata 15 változóval indult.

A találkozó helyszíne minden résztvevő számára ismert volt, több korábbi egyesületi összejövetel színtere, mely szintén fontos tényező lehet az együttgondolkodás oldottságának megvalósításához. A terveknek megfelelően először fél óra időtartamban a moderátor, jelen cikk szerzője megismertette a módszertan alapjaival a résztvevőket. A részvételi folyamatok, a rendszerdinamikai modellezés és a vizuális nyelv alkalmazásában rejlő lehetőségeket tekintettük át röviden. Ezt követően került sor az indító fogalmak kiválasztására a fent leírt módon, és az így nyert, térképen elhelyezésre kész formában rendelkezésre álló 15 változó nagyban megkönnyítette az első, feszélyezett lépések megtételét, ugyanakkor nem volt kényszer az ily módon adott változók felhasználása.

\footnotetext{
${ }^{23}$ http://inda.info.hu/
} 
A 2,5 órás intenzív munka eredményeként felvázolt diagram végül 42 fogalom ${ }^{24}$ felhasználásával készült el. (Ábra 3.) Ezek képezték a csomópontokat, melyeket 88 kapcsolat, úgynevezett oksági reláció kötött össze. A 88 kapcsolatból 79 pozitív, míg 9 negatív előjelü volt, és egyetlen, mindkét részről negatív előjelű kapcsolat volt két irányú. A csomópontokhoz, változókhoz minimum 1 maximum 11, átlagban 4,2 kapcsolat vezetett. Mindezeknek a statisztikáknak az elkészítését, valamint az igényes ábrázolást, az archiválást és a további elemzést megkönnyíti valamilyen szoftver alkalmazása. Jelen esetben a VUE (Visual Understanding Environment) ${ }^{25}$ szabad hozzáférésű szoftver segítette a munkának ezt a részét. A rendszertérképezés eredménye elsődlegesen fényképeken került rögzítésre, illetve kezelhető méretű volt az elkészített papír alapú térkép is. Mindezek felhasználásával utólag, de nem sokkal az események után került sor a szoftveren történő rögzítésre. A VUE szoftver is alkalmas lenne a folyamat közbeni rögzítésre, különösen, ha van egy módszertant ismerő, moderátori szerepet nem betöltő résztvevő, aki külső szemlélőként, pusztán adminisztrátorként részt tud venni az eseményen.

Ábra 3. - A rendszertérképezés folyamatának szervezési és lebonyolitási lépései

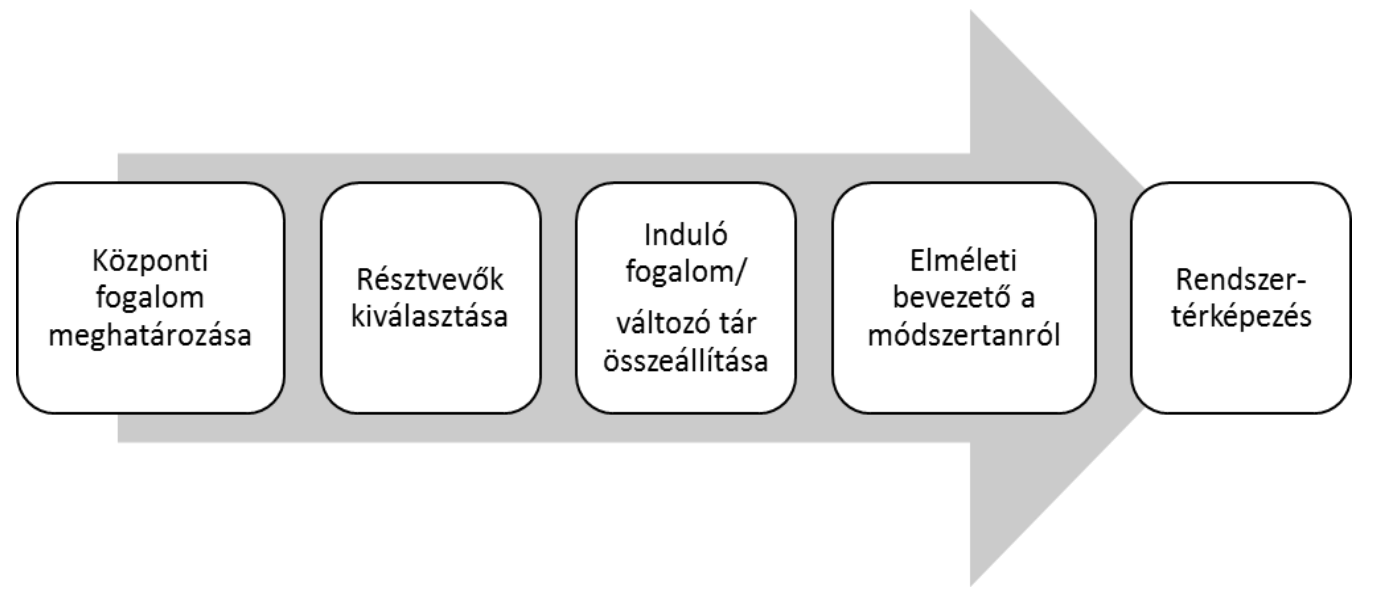

${ }^{24} 1$. demencia ismertsége 2. korai felismerés 3. információ mennyiség a neten 4. pozitív háziorvosi attitüd 5. szakorvosi háttér és kapacitás 6. Alzheimer Cafe 7. család jövedelme 8. prevenció 9. demenciával élők életminősége 10. palliatív szemlélet 11. ellátáshoz való hozzáférés 12. stigma 13. kutatás 14. adatgyüjtés 15. életvégi döntések lehetősége 16. demencia-barát kommunikáció 17. informáló kiadványok 18. önkéntes segítés 19. long-term-care, palliatív kapacitás 20. kapacitás igény ismerete 21. betegségspecifikus finanszírozás 22. rugalmas ellátás megvalósulása 23. ellátásban résztvevők kapcsolatai 24. illeszkedő jogi háttér 25. hozzátartozói támogatás eredményessége 26. hozzátartozó életminősége 27. beteg jövedelme 28. rugalmas ellátási formák 29. ápolói presztízs 30. otthoni ellátás feltétele 31 . hozzátartozó motiváltsága 32. lakhatási körülmény 33. ápolói burn-out 34. munkakörülmény 35. ápoló életminősége 36. ápolói létszám 37. ápolók speciális képzése 38. rugalmas munkalehetőség 39. TB juttatások köre 40. betegség-specifikus pénzbeli ellátás 41 . gondozási igény felmérése 42. rugalmas ellátás kapacitása

${ }^{25} \mathrm{http}$ ///vue.tufts.edu/ 
A részvételi rendszertérképezés eredményei

Az együttgondolkodás során elkészített térképet, a létrehozott komplex oksági diagramot már a helyszínen a résztvevőkkel közösen felületesen elemeztük. Már ekkor jól kirajzolódott, hogy a fogalmak többsége négy fő témakörhöz kötődik (Ábra 4.). A 42-ből 31 változó a következő szempontok egyikéhez tartozott:

- (szak)ápolói tényezők (9)

- orvosi ellátási háttér (8)

- hozzátartozói tényezők (8)

- információ - ismeret - ismertség (6)

Ábra 4. - Demenciával élők életminőségét befolyásoló 4 fö terület azonositása

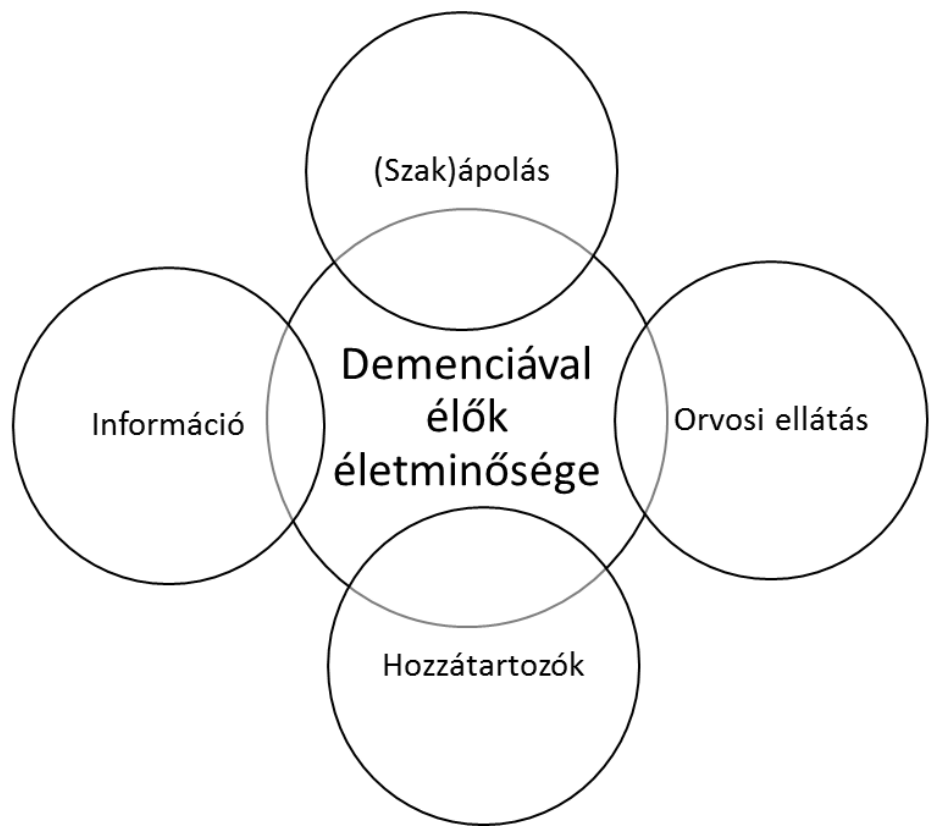

Tekintettel a résztvevők szakmai hátterének összetételére az ápolói- és orvosi ellátás előtérbe kerülése talán nem meglepő. Mindenképpen magyarázható az ápolói szempont elsődlegessége azzal, hogy a demenciában jártas szakemberek tisztában vannak a ténnyel, hogy a beteg életminősége szempontjából az ápolás minősége lesz a legmeghatározóbb. Az össztársadalmi érintettséget leginkább kifejező fő tényező az „információ-ismeretismertség” gondolatkör, mely egy külön központi fogalom, a stigmatizáció köré épült. A 
négy fö témakörbe nem besorolható fogalmak további utalást tettek az interdiszciplináris megközelítés szükségszerüségére, mivel például finanszírozási, jogi, kutatási vonatkozásokat vetettek fel. Mindamellett tehát, hogy a kiemelt témakörök tükrözik a résztvevők kompetenciájának, jártasságának fő területeit, egyértelműen megmutatkozik az azon túlmutató összefüggéskeresés.

Komplex oksági diagram készítésekor a pozitív és negatív irányú relációk ábrázolása teszi egyértelművé a kapcsolatot a változók között (Sedlacko et al., 2014). Tekintettel arra, hogy a központba helyezett változó alapvetően kimenet jellegü, így visszacsatolási hurkok könnyebben a különböző kiemelt témakörökön belül, illetve azok között létesíthetők (Ábra 5.).

Ábra 5. - Példa pozitív visszacsatolási körre-Orvosi ellátás témakörön belül

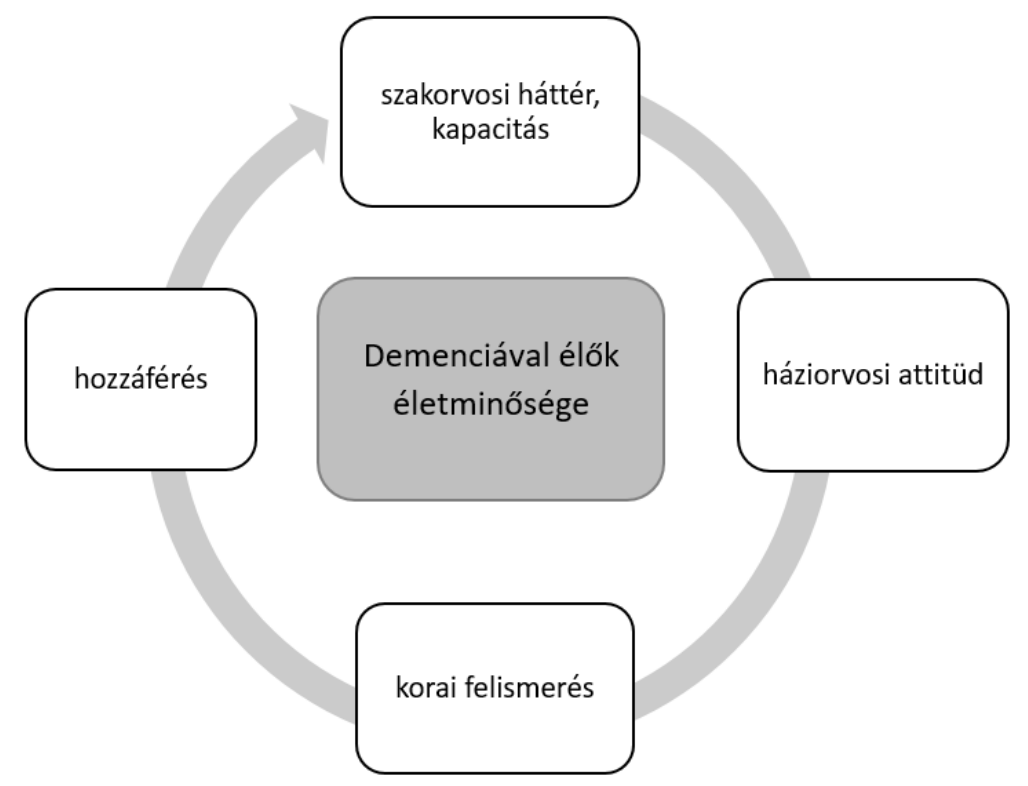

A kirajzolódott négy fö terület alapján a demenciával élők életminőségének javítása érdekében beavatkozást elsődlegesen az orvosi ellátás és az ápolás területén, a hozzátartozók támogatásában, valamint a betegséggel kapcsolatos minden típusú információ terjesztésében kell kezdeményezni. Ennek a négy témának az azonosítása akár egy stratégia megalkotásának prioritás meghatározó lépését is jelentheti (ld. Ábra 1.). 


\section{Következtetések}

A részvételi rendszertérképezés és komplex oksági diagram készítése a kísérlet alapján megfelelő eszköznek tünik ahhoz, hogy segítse egy összetett társadalmi probléma kezelését célul kitüző cselekvési terv megalkotásának kezdeti lépéseinél a tudás összegzését és az elsődleges beavatkozási pontok azonosítását. A demencia, mint elsődlegesen egészség- és szociálpolitikai szempontból megközelítendő, a demográfiai folyamatok alapján megbízhatóan elöre jelezhető mértékü terhet jelentő probléma, ideális témája volt a kísérletnek. A többi európai országhoz képest a probléma megoldására irányuló stratégia kidolgozásában hazánk lemaradásban van, így minden, a stratégiaalkotás folyamatába illeszthető lépés gyorsíthatja a cél elérését. A részvételi rendszerdinamikai modellezés újabb és újabb területeken való alkalmazása várható a jövőben, mivel eddigi tapasztalatok alapján alkalmas hosszú távú célok meghatározására, konkrét beavatkozási pontok azonosítására. Alkalmazása az egészségügyi és szociális területen még nemzetközi szinten is ritka. Az egészségtudományi és a közgazdasági terület egy-egy nagy, átfogó adatbázisában (Medline és EconLit) végzett keresés ${ }^{26}$ eredményeként mindössze 12 találatot kaptunk.

A kísérleti jelleggel végzett kutatás során a valamennyire már meglévő konzultatív kapcsolatokra építve, a már fennálló bizalmi viszonyt kihasználva próbáltuk az újszerü megközelítés alkalmazása miatti esetleges idegenkedést és az időigényt csökkenteni. A résztvevők számos pozitív visszajelzést adtak közvetlenül a kísérlet után, majd később is a gondolataikat, véleményüket monitorozó informális találkozók során. A megfogalmazottak közül kiemelhető, hogy többen hangsúlyozták a részvételük fontosságának megélését. Ez visszaigazolja a módszertan megfelelőségét egyrészt abban a tekintetben, hogy egyértelműen motiváló hatású volt a részvétel biztosítása, másrészt mivel valóban kommunikációs csatornát tudott biztosítani az egyetemi kutató és az idősellátásban résztvevő, ápolási otthont irányító gyakorlati szakember között. A vizuális ábrázolással magyarázták többen, hogy a kimerítő eszmecsere végén jó érzéssel telve búcsúztak, látva a munka gyümölcsét, a szó szerint tapintható, kézzel fogható produktumot, melyet mindenki a magáénak érzett, mivel látta a saját kézírását vagy

\footnotetext{
${ }^{26}$ keresési metódus: via EBSCOhost: ( "systems thinking" OR "system dynamics approach" OR "causal loop diagram" ) AND ( policy OR strategy ) AND ( health OR social ) AND ( participation OR participatory )
} 
olvashatta az általa megfogalmazott gondolatot, mely az egyik csomópontja lett az ábrának.

Moderátori tapasztalat, hogy valóban körültekintően kell megválasztani a résztvevőket, mivel egy problémakör globálisnak szánt áttekintését korlátozhatja, ha valamelyik szak/részterület képviselői túl nagy szerepet kapnak a reprezentáció mértéke vagy kommunikációs habitusuk alapján. A moderátornak akár aktív beavatkozásra, a szó átadására is készen kell állnia, ha a helyzet azt megköveteli. Bár egyszerünek tűnhet az ábrázolás feladata, de a résztvevőket többször emlékeztetni kellett arra, hogy igyekezzenek a probléma komplexitására gondolva minden oksági összefüggést megtalálni és ábrázolni. Ez a képesség feltehetően a gyakorlattal vagy részletesebb elméleti előkészítéssel javítható.

A négy azonosított fő befolyásoló tényező további elemekre bontása, a részfolyamatok mélyebb feltárása is lehetséges, illetve célszerü lenne. Látva, hogy egyes területeken a komplex áttekintést kevésbé szolgáló módon túlzott részletességgel történt a változók, okok feltárása, így felmerült lehetőségként, hogy az adott területre fókuszáló gondolattérképezés is kivitelezhető lenne az adott területen járatos szereplők bevonásával. A komplexitás háttérbe szorítása ilyen esetekben a rendszertérképezés egyéb irányú hasznosítását, mint az egészségügyi- és szociális területen az úgynevezett ,jó gyakorlatok” azonosítását, vagy a részvétel biztosításával a motivációt szolgálná.

A hozzátartozók hangsúlyos szerepét a demenciával élők ellátásában jelen kutatás eredménye is megmutatta. A családtagokat a gondozói szerepben érő pozitív és negatív hatások aktívan kutatott terület, és a többségében kvantitatív módszertan mellett már kvalitatív metódusok is feltünnek (Poland et al., 2014). A részvétel, mint módszertan, ilyen jellegü kutatásban történő alkalmazása mindenképpen megfontolandó következő lépésként, és a gondozó hozzátartozók mellett akár a demencia kezdeti stádiumában lévő érintettek bevonása sem irreális cél. Demenciával élőkkel végzett más kvalitatív módszertan alkalmazására van példa (Clare et al., 2008) a szakirodalomban, így ezek tapasztalataira lehet támaszkodni, ugyanakkor minden bizonnyal speciális felkészülésre van szükség, melynek ki kell terjednie a kórállapot tüneteinek ismeretén túl gyakorlati tapasztalat szerzésére, a demenciával élők mindennapi nehézségeinek megismerésére. 
Megbeszélés

A következtetésben összefoglalt tapasztalataink alapvetően alátámasztották az irodalomkutatás alapján felállított hipotézist, mely szerint a részvételi rendszerdinamikai modellezés alkalmas eszköz lehet valamely népegészségügyi probléma részének vagy egészének feltárására, egészség-politikai döntések meghozatalának, stratégiák megalkotásának támogatására (Leischow, 2006). A részvétel szempontjából igazolódott az a dilemma, hogy a szereplők kiválasztása egyúttal meghatározza a kimenetelt, többek között abban a tekintetben is, hogy a részvétel milyen jellegű bevonást jelent (Bishop, 2002). Esetünk leginkább „partnerségi” típusú részvételnek volt megfeleltethető, ami alapján a meghívott szakértők akár a szakpolitika megalkotói mellett müködő tanácsadó testületben is szerepet kaphatnának. A résztvevők kiválasztása szolgálta a holisztikus szemlélet és a tudás-szintézis megvalósulását, melyek többek között kritikus szempontok a módszer döntéstámogató funkciójának kiaknázásában. Tapasztalataink igazolták a kutató elődök azon meglátását is, hogy a rendszerdinamika egy probléma-vezérelt megközelítés, és a rendszertérképezésnek egy adott problémára kell fókuszálnia (Sedlacko et al., 2014).

Kutatásunkban ez a központi probléma a „demenciával élők életminőségének javítása” volt. Célunk az erre befolyással bíró tényezők azonosítása volt. Sikeresnek mondható a kísérlet abban a tekintetben, hogy sikerült endogén, a résztvevők által képviselt területen belül visszacsatolással rendelkező tényezőket megjeleníteni, feltárni (Richardson, 2011). A demenciával élők életminőségét meghatározó, és egymásra hatást gyakorló tényezők a térképünk alapján négy témakörhöz tartoztak. Ezeken a témakörökön belül számos visszacsatolás, összefüggés volt feltárható, és kisebb számban a témakörök között is voltak kapcsolatok. A négy fö témakörbe nem besorolható változók, mint a finanszírozási, jogi, kutatási vonatkozások jelentették az exogén tényezőket.

Eredményeink alapján a demenciával élők életminőségét az ápolási, az orvosi ellátási, a hozzátartozói háttér, valamint az információ több aspektusa határozza meg, és ez egybecseng más országok kész, akár már többször megújított demencia stratégiájával ${ }^{27}$, melyekben gyakran prioritásként szerepel a demenciával kapcsolatos közérthető és szakmai ismeretek terjesztése (információ), a stigmatizáció elleni küzdelem (információ),

${ }^{27}$ http://alzheimer-europe.org/Policy-in-Practice2/National-Dementia-Strategies (letölve: 2017.02.27.) 
az ápoló hozzátartozók támogatása (hozzátartozói háttér), az ellátórendszer bővítése és minőségi ellátás kiépítése (ápolási és orvosi ellátási háttér).

\section{Felhasznált irodalom:}

Aguero-Torres at al. (1998): Dementia is the major cause of functional dependence in the elderly. Threeyear follow-up data from a population-based study. American Journal of Public Health, 88(10), p. 14521456.

Annear, M. J. at al. (2015): What should we know about dementia in the 21st Century ? A Delphi consensus study. BMC Geriatrics, 15 (5), p. 1-13.

Bishop, P., G. Davis (2002): Mapping public participation in policy choices. Australian Journal of Public Administration, 61(1), p. 14-29.

Christensen, K., G. Doblhammer, R. Rau, J. W Vaupel (2009): Ageing populations: the challenges ahead. Lancet, 374(9696), p. 1196-1208.

Clare, L., J. Rowlands, E. Bruce, C. Surr, M. Downs (2008): 'I don't do like I used to do': A grounded theory approach to conceptualising awareness in people with moderate to severe dementia living in long-term care. Social Science and Medicine, 66(11), p. 2366-2377.

Etters, L., D. Goodall, and B.E. Harrison (2008): Caregiver burden among dementia patient caregivers: A review of the literature. Journal of the American Academy of Nurse Practitioners, 20(8), p. 423-428.

EUROCODE Project: Dementia in Europe Yearbook 2006, Alzheimer Europe; elérhető: http://ec.europa.eu/health/major_chronic diseases/diseases/dementia/index_en.htm\#fragment3

Fonareva, I. and B.S. Oken (2014): Physiological and functional consequences of caregiving for relatives with dementia. International Psychogeriatrics, 26(5), p. 725-747.

Király, G., A. Köves, Gy. Pataki, G. Kiss (2016): Assessing the Participatory Potential of Systems Mapping. Systems Research and Behavioral Science, 33(4), p. 496-514.

Király, G., A. Köves, Gy. Pataki, G. Kiss (2014): Rendszermodellezés és részvétel: egy magyar kísérlet tanulságai. Szociológiai Szemle, 24(2), p. 90-115.

Kling, M. A. at al. (2013): Vascular Disease and Dementias: Paradigm Shifts to Drive Research in New Directions. Alzheimers Dement, 9(1), p. 76-92.

Kovács, Tibor (2016): Demencia a mindennapi gyakorlatban - Összefoglaló közlemény. Korszerü Kaleidoszkóp, 2. évf. 2. szám, p. 3-8. 
Krol, M., J. Papenburg, and J. van Exel (2014): Does Including Informal Care in Economic Evaluations Matter? A Systematic Review of Inclusion and Impact of Informal Care in Cost-Effectiveness Studies. PharmacoEconomics, 33(2), p. 123-135.

Lane, D. C. (2007): The power of the bond between cause and effect: Jay Wright Forrester and the field of system dynamics. System Dynamics Review, 23(2-3), p. 95-118.

Leischow, S., B. Milstein (2006): Systems Thinking and Modeling for Public Health Practice. American Journal of Public Health, 96(3), p. 403-405.

Morrissey et al. (2006): Alzheimer's cafe for people with and affected by dementia, Nursing Times, 102(15), p. 29-31.

Poland, F., S. Mapes, H. Pinnock, C. Katona, S. Sorensen, C. Fox, I.D. Maidment (2014): Perspectives of carers on medication management in dementia: lessons from collaboratively developing a research proposal. BioMed Central Research Notes, 7, p. 463.

Priority Medicines for Europe and the World - A Public Health Approach to Innovation. (2013). World Health Organization

Richardson, G. P. (2011): Reflections on the Foundations of System Dynamics. System Dynamics Review, 27(3), p. 219-243.

Sedlacko, M., A. Martinuzzi, I. Røpke, N. Videira, P. Antunes (2014): Participatory systems mapping for sustainable consumption: Discussion of a method promoting systemic insights. Ecological Economics, 106, p. 33-43.

Vennix, J. A. M. (1996): Group Model Building - Facilitating Team Learning Using System Dynamics; Chapter 2: System dynamics: problem identification and system conceptualization. P. 43-45.

World Alzheimer Report 2010: The Global Economic Impact of Dementia. Alzheimer's Disease International

World Alzheimer Report 2015: The Global Impact of Dementia. Alzheimer's Disease International 
3.2.2 Older New Zealanders in caregiving roles: Psychological functioning of caregivers of people living with dementia ${ }^{28}$

\section{Abstract}

Research suggests that caregiving can have both positive and negative effects on psychological functioning. It is, however, less understood how these positive and negative effects interact within individuals. The present study aimed to identify different patterns of psychological functioning and their correlates among caregivers of dementia patients. The sample included 336 older caregivers. Latent profile analysis revealed three distinct profiles. The optimally functioning profile was characterized by high levels of positive outcomes and low levels of depression. Those with a suboptimally functioning profile reported low levels of positive outcomes and increased depression symptoms. The poorly functioning profile displayed extremely high levels of depression symptoms and extremely low levels of positive outcomes. Differentiation among groups was driven by differences in social support and to a lesser extent by socio-demographic factors and caregiving experience. Results suggest that caregiving is not necessarily a burdensome role and highlight the role of social relationships.

Keywords: Alzheimer's disease, caregiver, dementia, depression, latent profile analysis (LPA), mental health, psychological functioning, social support, wellbeing

New Zealand, like other developed countries, has an ageing population. According to the most recent census (Statisctics New Zealand, 2013), 14.3\% of the New Zealand population were aged 65 years or older and the proportion of the $65 \mathrm{p}$ population is expected to double in the next 50 years. Prevalence of dementia is growing parallel with population ageing (Prince et al., 2013). In 2016, the estimated number of people living with dementia in New Zealand was more than 62,000. It is predicted that, by 2050, this number will be around 170,000. As dementia progresses, patients require higher levels of care, which can pose significant challenges for the caretaker. Consequently, promoting

\footnotetext{
${ }^{28}$ BCE GDI kérése alapján a 3.2.2 fejezet a következő publikáció szó szerinti szövegét tartalmazza: Fekete, M., Szabo, A., Stephens, C., Alpass, F. (2019a). Older New Zealanders in caregiving roles: Psychological functioning of caregivers of people living with dementia. Dementia, 18(5), 1663-78.
} 
pathways to caregiver wellbeing to better support people living with dementia is a key objective of the New Zealand Framework for Dementia Care (Ministry of Health, 2013).

The strains and gains of caregiving

Caregiving of people living with dementia can be a challenging and burdensome role in life. The consequences of providing care for somebody who is suffering from a chronic illness have long been one of the major foci of caregiving research (Wennberg, Dye, Streetman-Loy, \& Pham, 2015). Studies have shown that caregiving burdens are associated with a wide range of negative health outcomes, including depression and related mood disorders (Joling et al., 2010), cognitive impairment (Vitaliano, Murphy, Young, Echeverria, \& Borson, 2011), and poor physical health (Fonareva \& Oken, 2014).

Despite the strains and challenges involved in caring for dementia patients, the caregiving experience can also present personal gains. In recent years, there has been increasing interest in understanding the positive effects of caregiving on psychological wellbeing (Kramer, 1997). For example, caregivers have been shown to derive psychological benefits from their caregiving-related responsibilities, such as increased life satisfaction, a more positive outlook on life, self-affirmation, and personal growth (Rozario, MorrowHowell, \& Hinterlong, 2004; Sanders, 2005; Tarlow et al., 2004). These studies suggest that, although caregiving can contribute to mental and physical health decline, not all caregivers would necessarily experience negative consequences. In contrast, adopting caregiving as a productive and meaningful role provides an opportunity for personal growth and to achieve a sense of mastery (Rozario et al., 2004; Sanders, 2005).

The dynamic interplay of positive and negative factors involved in caregiving can lead to vastly different individual experiences. However, previous investigations focussed mainly on establishing associations among key variables that characterize entire samples as opposed to trying to shed light on subgroups of people who experience caregiving in unique and distinctive ways. This type of inattention to divisions within the caregiver population and relevant differences across groups has been highlighted as one of the main methodological problems in the caregiving literature (Kramer, 1997). 


\section{Caregiver profiles}

There has been a handful of studies exploring caregiving profiles in dementia based on caregiver characteristics and responsibilities. For example, Kraijo, Brouwer, de Leeuw, Schrijvers, and van Exel (2012) examined caregivers' motivations to provide care, burdens associated with caregiving, perceived social support and needs for support, and coping strategies. Using Q-analysis, they identified five distinct profiles with increasing subjective burden and decreasing ability to cope with strains. In a more recent study, Janssen et al. (2017) investigated caregiver profiles based on two dimensions: (1) caregiver and care-recipient characteristics, such as age or severity of dementia and (2) the strain or burden associated with the caregiving responsibilities. They differentiated among 'older low strain', 'older intermediate strain', 'older high strain', 'younger low strain', and 'younger high strain' profiles. They found that quality of life was lower in profiles characterized by higher strain.

Although these investigations used a person-oriented approach, they created profiles based on the burdens or stressors involved in caregiving for persons living with dementia. However, previous research shows that not every caregiver reports poor health outcomes or perceive this responsibility as burdensome or stressful (Kramer, 1997; Rozario et al., 2004; Sanders, 2005; Tarlow et al., 2004). Some caretakers report positive outcomes and high quality of life, even when they spend long hours taking care of someone with severe dementia and experience enormous challenges. To address this gap, the present study aimed to explore different profiles of psychological functioning in a sample of older caregivers of dementia patients. A second objective of the paper was to identify risk and protective factors that foster or hinder psychological wellbeing of dementia caregivers.

\section{Present study}

We adopted a person-oriented approach (using LPA) to identify groups of caregivers with similar patterns of psycho-social functioning. Based on previous research findings with respect to the strains of caregiving, we expected to find a vulnerable or 'at risk' group who display negative psycho-social outcomes, such as high levels of depression, low levels of quality of life and life satisfaction, and poor mental health. On the other hand, drawing on research emphasizing the gains associated with caregiving, we predicted that 
a second group would emerge characterized by resilience and healthy psychosocial functioning, i.e. low levels of depression, high levels of quality of life and life satisfaction, and good mental health. As our investigation was exploratory, we did not rule out the possibility of other caregiving profiles to be present in our sample. Additional profiles could display a combination of positive and negative psycho-social markers or they might occupy an intermediate position demonstrating moderately high levels of positive/negative outcomes.

The emerging caregiving profiles were examined in relation to socio-demographic factors, caregiving responsibilities, and social support to gain a better understanding of the factors that contribute to or hinder positive psychological functioning. Female gender, younger age, and spousal relationship to the care-recipient have been previously identified as risk factors for poor wellbeing among caregivers for dementia patients (Etters, Goodall, \& Harrison, 2008; Fonareva \& Oken, 2014; Wennberg et al., 2015; Zanetti et al., 1998). With respect to the circumstances of caregiving, research findings are rather inconclusive with some studies suggesting no or minimal effects, while others emphasizing the significant role of caregiving factors, such as intensity and frequency of care or the characteristics of the care-recipient (e.g. age), on psychological outcomes (Vellone et al., 2011; Wolff \& Kasper, 2006).

Finally, changes in the quality and quantity of social interactions have been documented as important factors contributing to psychological outcomes in caregivers. For example, loneliness and poor access to social support have been found to be key predictors of depression symptoms and caregiving burdens among caregivers of people living with Alzheimer's disease (Beeson, Horton-Deutsch, Farran, \& Neundorfer, 2000; Beinart, Weinman, Wade, \& Brady, 2012).

\section{Method}

Design and sample

Data were collected between 2010 and 2014 as part of the New Zealand Health, Work, \& Retirement Study (Towers, Stevenson, Breheny, \& Allen, 2016). The sample included 336 caregivers of people with dementia ( $70.2 \%$ female, $37.2 \%$ of Maori descent). The average age of caregivers was $\mathrm{M}=65$ years (range: $49-88, \mathrm{SD}=8$ years). The average age 
of care recipients living with dementia or Alzheimer's disease was $\mathrm{M}=82$ years (range: $47-101, \mathrm{SD}=9$ years). One-third (31.5\%) of caregivers were living with the care recipient. More than half of the dyads were based on parent-child type relationships (52.4\%; mother-in-law and father-in-law were counted as parents); $19 \%$ were spousal connections, $7.7 \%$ of caregivers provided care to other relatives including son/daughter or brother/sister, and $17.9 \%$ to non-relatives (friends or others). The remaining $3 \%$ did not answer this question. In terms of marital status, $69.94 \%$ of caregivers were married or lived in a de facto relationship. Of all respondents, $21.73 \%$ worked full-time, $25.30 \%$ were employed part-time, and $30.36 \%$ indicated that they were retired. The remaining $22.62 \%$ did not answer this question.

\section{Procedure}

Participants received a postal survey along with a free-post return envelope. The survey included questions pertaining to health and wellbeing, work and retirement, social support and participation, income and financial wellbeing, and demographics. For the analyses reported in the current paper, we included participants who provided care for someone living with Alzheimer's disease or dementia at any stage over the course of the study. As it is a longitudinal data set, some of the caregivers appeared in this role more than once. These people were enrolled only once, using the data from their first appearance.

\section{Measures}

Caregiving responsibilities. Caregiving responsibilities were measured in terms of frequency of caregiving (anchored by $1=$ every day, $2=$ several times per week, $3=$ once a week, $4=$ =nce every few weeks, $5=$ less often), length of caregiving (measured in years), living arrangements, and relationship to the care recipient.

Socio-economic status (SES). SES was assessed with the Economic Living Standards Index (ELSI; Jensen, Spittal, Crichton, Sathiyandra, \& Krishnan, 2002). ELSI assesses restrictions on ownership of assets (eight items; e.g. 'heating in main rooms'), restrictions due to cost in social participation (six items; e.g. "visit hairdresser once every three months'), economizing behaviour (eight items; e.g. 'cut back on shopping'), and selfreported satisfaction with standard of living (three items). Item scores are combined into 
a composite measure (range: $0-31$ ) where higher scores reflect higher economic living standards.

Social support. Three instruments were used to measure social support and the quality and quantity of social relationships: The Practitioner Assessment of Network Type (Wenger, 1991) measures frequency of contact with family, friends, and neighbours (three items; sixpoint scale ranging from daily to never). The Social Provisions Scale (Cutrona \& Russell, 1987) examines six relational provisions, such as attachment, social integration, reassurance of worth, reliable alliance, guidance, and opportunity for nurturance. Respondents have to rate two positive and two negative statements regarding all six provisions using a four-point scale ('strongly disagree' to 'strongly agree'). Sample items for the 'guidance' relation are 'I have someone to talk to about decisions in my life' and 'There is no one I can turn to in times of stress' (reverse scored). Items can be summarized to form a composite measure where higher scores indicate greater degree of perceived support. The De Jong Gierveld Loneliness Scale was used to measure emotional and social isolation (Gierveld, van Groenou, Hoogendoorn, \& Smit, 2009). Participants rated statements, such as 'I miss having a really close friend' (emotional loneliness) and 'There are enough people I feel close to' (social loneliness), on a threepoint scale (anchored at $1=$ no, $2=$ more or less, and $3=y e s$ ).

Psychological functioning. Psychological functioning was operationalized in terms of self-rated mental health (SF-12; Ware, Keller, \& Kosinski, 1998), depression symptoms (CESD-10; Kohout, Berkman, Evans, \& Cornoni-Huntley, 1993), quality of life (CASP12; Wiggins, Netuveli, Hyde, Higgs, \& Blane, 2008), and life satisfaction (Inglehart, Basanez, Diez-Medrano, Halman, \& Luijkx, 2004). The SF-12 is a generic health-related quality of life instrument. Participants were asked to give responses to statements, such as 'How much time during the past 4 weeks have you felt calm and peaceful?' on a fivepoint scale ('none of the time' to 'all of the time'). Total scores can range between 0 and 100 with higher scores indicating better mental health status. Self-reported depression symptoms were examined using the 10-item version of the Center for Epidemiologic Studies Depression Scale. Items, such as 'I felt hopeful about the future' (reverse scored), were rated on a four-point scale ('rarely or none of the time' to 'all of the time'). Scores can range between 0 and 30, where a total score of 10 or higher indicates depression symptomology. The CASP-12, an instrument specifically designed for the older population, was used to assess quality of life. It consists of four domains (Control, 
Autonomy, Self-realization, and Pleasure) measuring different aspects of quality of life with statements, such as 'I enjoy the things that I do' (Pleasure), on a four-point scale ('often' to 'never'). Total scores can range from 0 to 36 , where higher scores represent a higher level of quality of life. Life satisfaction was assessed by one item adapted from the World Value Survey: 'All things considered, how satisfied are you with your life as a whole these days?'. Responses were given on a five-point scale ('very dissatisfied' to 'very satisfied').

Data analysis

LPA was conducted in Mplus (www.statmodel.com; Muthe'n \& Muthe'n, 2012) on responses to measures of psychological functioning. The Bootstrap Likelihood Ratio Test (BLRT), the Bayesian information criterion (BIC), the entropy, and the probability of class membership were used to compare models with increasing profile numbers. A significant BLRT indicates that the model with $k$ number of profiles has an improved fit to the data than the model with $k-1$ number of profiles. Models with lower BIC score, higher entropy, and posterior class membership demonstrate better fit to the data. The recommended threshold for entropy and probability of class membership is .80. Emerging profiles were also expected to account for at least $10 \%$ of the total sample (Bauer \& Curran, 2004; Clark \& Muthen, 2009; Muthe'n \& Muthe'n, 2012). Profiles were compared based on demographic characteristics using inferential statistics. Three multinomial logistic regression models were tested to identify sociodemographic, caregiving and social support variables distinguishing across profiles. The Nagelkerke's pseudo $\mathrm{R}^{2}$ and the Bayesian Information Criterion (BIC) were used to compare the fit of the three domain-specific multinomial logistic regression models. The Nagelkerke's pseudo $\mathrm{R}^{2}$ can range between 0 and 1 with higher values indicating a better fit. Smaller BIC indicates better model fit and a difference of 10 is considered to indicate improved fit (Raftery, 1995). 


\section{Results}

Latent profile analysis

Models with profiles ranging from 2 to 4 were contrasted. The four-profile model produced a non-significant BLRT indicating that the three-profile model provided a better fit to the data with entropy and posterior profile membership probabilities higher than .80 (Table 1). The first profile ( $\mathrm{n}=202,60.3 \%$ of the sample) was characterized by optimal psychological functioning. Mental health, quality of life, and life satisfaction in this group were high, whereas self-reported depression symptoms were low. Participants in the second profile $(\mathrm{n}=96,28.7 \%)$ displayed suboptimal psychological functioning with increased levels of depression symptoms and lower than average levels of mental health, quality of life, and life satisfaction. The final profile $(n=37,11 \%)$ included respondents with very high levels of depression symptoms and very low levels of mental health, quality of life, and life satisfaction indexing poor psychological functioning (Figure 1).

Table 1. Latent Profile analysis model fit statistics

\begin{tabular}{llllll}
\hline Number of profiles & BLRT & BIC & ABIC & Entropy & Posterior membershi \\
& & & & & \\
\hline 2 profiles & $373.73^{*}$ & 5771.27 & 5730.03 & .856 & $.92-.97$ \\
3 profiles & $123.74^{*}$ & 5672.35 & 5615.25 & .800 & $.88-.94$ \\
4 profiles & 50.40 & 5649.29 & 5576.33 & .853 & $.88-.97$
\end{tabular}

$\overline{\text { Note. }}{ }^{*} p<.05$; BLRT; Bootstrap Likelihood Ratio Test, BIC; Bayesian information criterion;

ABIC; Adjusted BIC

Figure 1. Prototypical profile structures.

Scores on the $\mathrm{Y}$ axis are $\mathrm{z}$-scores $(\mathrm{M}=0, \mathrm{SD}=1)$. The direction of the bars indicates whether participants scored above or below the mean. Longer bars represent greater deviation from the mean. Higher scores indicate more depression symptoms, better mental health, higher levels of quality of life, and higher levels of life satisfaction. Error bars indicate standard error of the mean. 


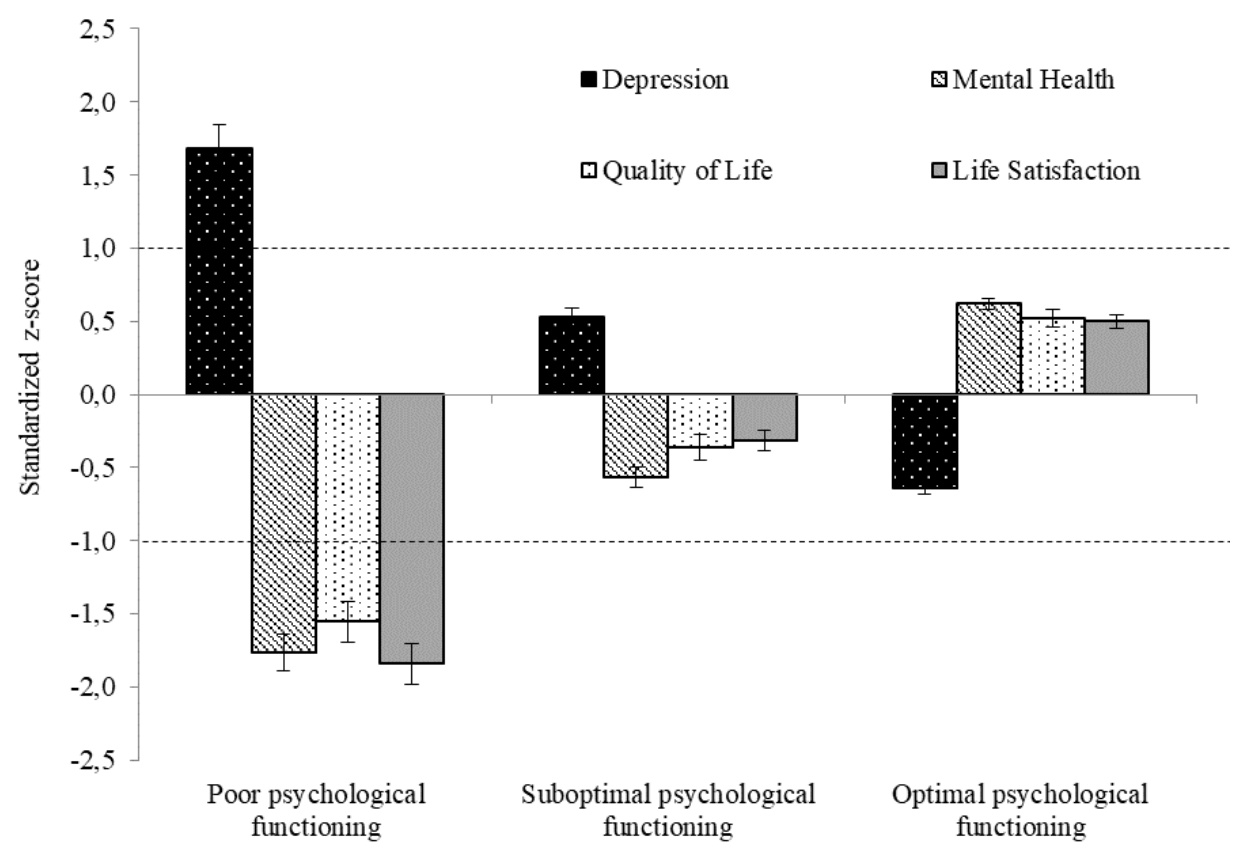

Demographic characteristics of caregiving profiles

Analyses indicated no significant differences across profiles based on ethnicity, gender, marital status, and work status (Table 2). However, participants in the poorly functioning profile were significantly younger $(\mathrm{M}=61.57, \mathrm{SD}=7.55)$ than those in the suboptimally $\left(\mathrm{M}=66.39, \quad \mathrm{SD} \_8.55\right)$ and optimally $(\mathrm{M}=64.87, \quad \mathrm{SD}=7.81)$ functioning profiles; $\mathrm{F}(2,332)=4.86, \mathrm{p}=.008, \mathrm{n}^{2}=.03$.

Table 2. Demographic Characteristics of Caregiving Profiles

\begin{tabular}{|c|c|c|c|c|c|c|}
\hline & \multicolumn{2}{|c|}{ Poor functioning } & \multicolumn{2}{|c|}{ Suboptimal functioning } & \multicolumn{2}{|c|}{ Optimal functioning } \\
\hline & $N$ & Column \% & $N$ & Column \% & $N$ & Column \% \\
\hline \multicolumn{7}{|l|}{ Gender } \\
\hline Female & 21 & $56.8 \%$ & 69 & $71.9 \%$ & 145 & $71.8 \%$ \\
\hline Male & 16 & $43.2 \%$ & 27 & $28.1 \%$ & 57 & $28.2 \%$ \\
\hline \multicolumn{7}{|l|}{ Ethnicity* } \\
\hline Not of Māori Descent & 24 & $64.9 \%$ & 52 & $54.2 \%$ & 134 & $66.3 \%$ \\
\hline Māori Descent & 13 & $35.1 \%$ & 44 & $45.8 \%$ & 68 & $33.7 \%$ \\
\hline \multicolumn{7}{|l|}{ Marital status } \\
\hline Not married nor de facto & 12 & $33.3 \%$ & 29 & $30.5 \%$ & 53 & $26.4 \%$ \\
\hline Married or de facto & 24 & $66.7 \%$ & 66 & $69.5 \%$ & 148 & $73.6 \%$ \\
\hline \multicolumn{7}{|l|}{ Work status } \\
\hline Full-time & 7 & $25.9 \%$ & 22 & $28.2 \%$ & 52 & $29.1 \%$ \\
\hline Part-time & 11 & $40.7 \%$ & 16 & $20.5 \%$ & 60 & $33.5 \%$ \\
\hline Retired & 9 & $33.3 \%$ & 40 & $51.3 \%$ & 67 & $37.4 \%$ \\
\hline
\end{tabular}

Note. * Māori are the indigenous population of New Zealand. 
Prediction of profile membership based on socio-demographic caregiving and social support variables

Three domain-specific multinomial logistic regressions were performed. Results (Nagelkerke's pseudo $\mathrm{R}^{2}$, BIC, and odds ratios with confidence interval) are reported in Table 3.

Table 3. Fit Statistics and Odds Ratios of the Domain-specific Multinomial Logistic Regressions

\begin{tabular}{|c|c|c|c|c|c|c|}
\hline & \multicolumn{2}{|c|}{ Poor $v s$ Optimal } & \multicolumn{2}{|c|}{ Suboptimal vs Optimal } & \multicolumn{2}{|c|}{ Suboptimal vs Poor } \\
\hline & $\operatorname{Exp}(B)$ & $95 \% C I$ & $\operatorname{Exp}(B)$ & $95 \% C I$ & $\operatorname{Exp}(B)$ & $95 \% C I$ \\
\hline \multicolumn{7}{|c|}{ Model 1: Socio-demographics } \\
\hline Age & 0.95 & $(0.90 ; 1.01)$ & 1.01 & $(0.97 ; 1.04)$ & 1.06 & $(0.99 ; 1.13)$ \\
\hline ELSI & $0.83^{* * *}$ & $(0.79 ; 0.88)$ & $0.93 * * *$ & $(0.89 ; 0.97)$ & $1.12 * * *$ & $(1.06 ; 1.18)$ \\
\hline Gender & 0.43 & $(0.18 ; 1.02)$ & 1.00 & $(0.56 ; 1.79)$ & 2.33 & $(0.95 ; 5.70)$ \\
\hline Ethnicity & 1.59 & $(0.64 ; 3.93)$ & 0.74 & $(0.44 ; 1.23)$ & 0.47 & $(0.19 ; 1.17)$ \\
\hline Marital status & 1.02 & $(0.41 ; 2.55)$ & 0.94 & $(0.52 ; 1.68)$ & 0.92 & $(0.36 ; 2.34)$ \\
\hline Working status & 1.35 & $(0.53 ; 3.41)$ & 1.77 & $(0.98 ; 3.21)$ & 1.31 & $(0.51 ; 3.39)$ \\
\hline \multicolumn{7}{|l|}{$B I C=587.42$} \\
\hline \multicolumn{7}{|l|}{$R^{2}=.25$} \\
\hline \multicolumn{7}{|l|}{ Model 2: Caregiving factors } \\
\hline Frequency of care & 1.00 & $(0.70 ; 1.43)$ & 1.06 & $(0.81 ; 1.39)$ & 1.06 & $(0.72 ; 1.58)$ \\
\hline Age of the person cared for & 0.98 & $(0.94 ; 1.02)$ & 0.99 & $(0.97 ; 1.03)$ & 1.01 & $(0.97 ; 1.06)$ \\
\hline Length of caregiving in years & $0.85^{*}$ & $(0.75 ; 0.97)$ & 1.00 & $(0.97 ; 1.04)$ & $1.18^{*}$ & $(1.03 ; 1.34)$ \\
\hline Living arrangements & 1.39 & $(0.53 ; 3.63)$ & 0.96 & $(0.50 ; 1.83)$ & 0.69 & $(0.25 ; 1.92)$ \\
\hline Relation to care recipient & 0.49 & $(0.15 ; 1.54)$ & 0.83 & $(0.40 ; 1.73)$ & 1.70 & $(0.50 ; 5.91)$ \\
\hline \multicolumn{7}{|l|}{$B I C=574.16$} \\
\hline \multicolumn{7}{|l|}{$R^{2}=.05$} \\
\hline \multicolumn{7}{|l|}{ Model 3: Social support } \\
\hline Social Contact & $0.42 * * *$ & $(0.28 ; 0.78)$ & $0.66^{*}$ & $(0.46 ; 0.94)$ & 1.57 & $(0.88 ; 2.80)$ \\
\hline Social Provisions & $0.86^{* * *}$ & $(0.80 ; 0.93)$ & $0.92 * * *$ & $(0.88 ; 0.96)$ & 1.07 & $(0.99 ; 1.14)$ \\
\hline Loneliness & $2.08 * * *$ & $(1.52 ; 2.84)$ & $1.53 * * *$ & $(1.23 ; 1.90)$ & $0.74 *$ & $(0.56 ; 0.97)$ \\
\hline \multicolumn{7}{|l|}{$B I C=382.42$} \\
\hline$R^{2}=.44$ & & & & & & \\
\hline
\end{tabular}

Note . $\mathrm{CI}=$ confidence interval; $\mathrm{BIC}=$ Bayes Information Criterion; Gender $(0=$ female, $1=$ male $)$; Ethnicity $(0=$ non-Māori, $1=$ Māori $)$; Marital status $(0=$ not in a relationship, $1=$ in a relationship $)$; Working status $(0=$ retired, $1=$ working); Living arrangements $(0=$ not living with the care recipient, $1=$ living with the care recipient); Relation to care recipient $(0=$ not relative, $1=$ relative $) .{ }^{*} p<0.05 ;{ }^{* *} p<0.01 ;{ }^{* * *} p<0.001$ 
Distinguishing the optimally and poorly functioning profiles

Poorer economic living standards, less caregiving experience, higher levels of loneliness, less frequent social contact, and lower levels of social provisions were predictive of the poorly functioning profile. Specifically, one standard deviation increase in economic living standards was associated with a 1.20 increase in the odds of being assigned into the optimally functioning profile as opposed to the poorly functioning profile. Similarly, given a one standard deviation increase in the year spent in the caregiving role, the odds of having an optimally vs. poorly functioning profile are 1.18 times more likely. One standard deviation increments in social provisions and social contact were associated with a 1.16 and 2.38 increase in the odds of being characterized by an optimally functioning profile as opposed to a poorly functioning profile. Finally, a one standard deviation increase in loneliness was associated with a 2.08 increase in the odds of having a poorly functioning psychological profile compared to an optimally functioning profile.

Distinguishing the optimally and suboptimally functioning profiles

Comparison of the suboptimally and optimally functioning profiles revealed economic living standards, social provisions, social contact, and loneliness as significant predictors. One standard deviation increase in economic living standards was associated with a 1.08 increase in the odds of being assigned into the optimally, as opposed to the suboptimally, functioning profile. One standard deviation increments in social provisions and social contact were associated with a 1.09 and 1.52 increase in the odds of being characterized by an optimally functioning profile compared to a suboptimally functioning profile. One standard deviation increase in loneliness, on the other hand, was associated with a 1.53 increment in the odds of having a suboptimally, as opposed to an optimally, functioning profile.

Distinguishing the poorly and suboptimally functioning profiles

Economic living standards, length of caregiving experience, and loneliness significantly differentiated between the poorly and suboptimally functioning profiles. One standard deviation increase in economic living standards was associated with a 1.12 increase in the odds of being assigned into the suboptimally functioning profile as opposed to the poorly 
functioning profile. One standard deviation increase in the length of caregiving experience was associated with a 1.18 increase in the odds of having a suboptimally vs. poorly functioning profile. Finally, a one standard deviation increase in loneliness was associated with a 1.35 increase in the odds of being in the poorly functioning profile compared to the suboptimally functioning profile.

Model fit

Both the BIC and the Nagelkerke's pseudo $\mathrm{R}^{2}$ suggest that the social support domain model has the best fit.

\section{Discussion}

Although caregivers of dementia patients might face very similar difficulties, no two caregivers will be affected by these challenges the same way. The primary goal of the present study was to explore different patterns of psychological functioning among dementia caregivers by investigating differences in mental health, depression symptoms, quality of life, and life satisfaction. In addition, we aimed to elucidate some of the sociodemographic, caregiving, and social support factors that might contribute to differences in psychological wellbeing among caregivers of dementia patients.

The analysis revealed three distinct groups of caregivers based on their psychological functioning. In line with our hypothesis, we identified a poorly functioning or at risk subgroup, characterized by adverse psychological outcomes. In addition, and as expected, a subgroup with an optimally functioning or resilient profile emerged expressing high levels of wellbeing and low levels of psychological problems. Finally, the third group occupied an intermediate position with moderately low levels of wellbeing. The majority of the sample belonged to the optimally functioning group, reporting high levels of wellbeing. A smaller proportion (approximately 11\%) of the participants was characterized by negative psychological outcomes. This confirms previous research showing that caregiving can have both positive and negative effects on caregivers' wellbeing (Kinney \& Stephens, 1989; Kramer, 1997). In addition, 28.7\% of the sample reported suboptimal functioning with lower levels of mental health, quality of life, and life satisfaction and increased depression symptoms. The psychological wellbeing of this 
group was below an optimal level, which could indicate caregivers who are at risk for compromised mental health.

Next, we examined differences across profiles in demographic, caregiving, and social support variables to identify potential risk and protective factors for older dementia caregivers. Of the demographic variables, economic living standards had significant effects. The optimally functioning group was characterized by significantly better economic conditions than the other two profiles. Higher SES has been generally linked to better mental health (Glymour, Avendano, \& Kawachi, 2014) and caregivers with more resources tend to find their responsibilities less stressful (Pearlin, Mullan, Semple, \& Skaff, 1990; Schulz, Obrien, Bookwala, \& Fleissner, 1995).

Length of caregiving experience was the only caregiving factor that significantly predicted profile membership. Specifically, participants in the poorly functioning group had less caregiving experience than caregivers in the optimally or suboptimally functioning profiles. Adjusting to the caregiver role can be challenging. New caretakers might cope less effectively with the difficulties involved in looking after a person with dementia. It has been shown that caregivers with more experience attain more psychological benefits (Hogstel, Curry Cox, \& Walker, 2005), as they develop more adaptive strategies to combat stress associated with caregiving (Charlesworth et al., 2017; Greenwood \& Habibi, 2014).

Finally, results indicated a clear pattern across groups in social support indicators: the optimally functioning group reported the most extended social network, most social provisions, and the lowest level of loneliness. The poorly functioning profile was characterized by the lowest value on all social support variables, whereas the suboptimally functioning group scored in-between. According to the conceptual model of Alzheimer's caregivers' stress, social support is a key mediator in the psychological adjustment of caregivers (Pearlin et al., 1990). Social support not only acts as a buffer but also prevents the development of secondary stressors. Our results provide support for the model showing that dementia caregivers with optimal psychological functioning have a wider network and access more social provisions. Although the poorly and suboptimally functioning groups could not be distinguished based on social contact and provisions, loneliness emerged as a significant predictor. Results indicated that caregivers with poor 
psychological functioning were more isolated and lonelier than those in the suboptimally functioning group.

In sum, of the three domains tested in this study, social support (measured in the form of contact, provisions, and loneliness) was the best predictor of psychological profiles. Caregiving factors had a weak predictive power with only caregiving experience significantly differentiating among profiles. Socio-demographic characteristics were better at predicting profile membership but this was driven mainly by differences in SES.

\section{Implications for interventions}

The relatively high ratio of participants reporting poor or suboptimal psychological functioning highlights the importance of developing interventions to distinguish between different profiles of caregivers, and, thus, identifying vulnerable or 'at risk' groups within the caregiver population. Former publications have emphasized the importance of identifying factors impacting wellbeing that are changeable, as they can be the target of effective interventions (Alves, Teixeira, Azevedo, Duarte, \& Paul, 2016; Gitlin et al., 2003; Pinquart \& Sorensen, 2004; Wennberg et al., 2015). While SES is hard to influence, recognizing its effect on wellbeing outcomes is important to find the best-fitted way for support.

Caregiving responsibilities had the weakest influence on psychological functioning. The only factor that significantly differentiated among profiles was caregiving experience. Neither frequency of caregiving nor care-recipient characteristics were predictive of profile membership. This suggests that it is not the intensity of caregiving that can be harmful but the lack of experience dealing with the associated burdens and challenges. One way to enhance the wellbeing of new caregivers is by providing them with necessary information about the difficulties and challenges they might encounter, by helping them develop adaptive strategies, and by ensuring they set realistic expectations.

Seeking instrumental and emotional social support has been shown to be effective coping strategies to deal with the burdens associated with dementia caregiving (Beinart et al., 2012). Our results indicated personal contact, loneliness, and strong social provisions as the most important contributing factors to psychological functioning. Development and mobilization of social networks should be emphasized as core facets of interventions for 
dementia caregivers. They can incorporate psycho-educational and training elements, along with more informal forms of provision. Dementia is still a stigmatizing condition, which might discourage caregivers to participate in intervention programmes (de Vugt \& Verhey, 2013; MacRae, 1999; Werner, Mittelman, Goldstein, \& Heinik, 2012). Support groups can be helpful by reminding caregivers that they are not alone in their challenging role. Previous studies have highlighted that interventions should be delivered based on the individual needs of caregivers (Schulz et al., 2003). Our person-centred analysis aimed to contribute to this approach. By profiling caregivers based on psychological and social characteristics, tailored interventions can be offered.

\section{Limitations and strengths}

Firstly, dementia is a progressive disease and we had no information about the clinical stage of the care recipient's condition, which can have a substantial influence on the caregiver's wellbeing. Secondly, our analyses were cross-sectional; therefore, we cannot make conclusions regarding causality. Although social support is likely to predict better health outcomes, it is also likely that those with higher levels of wellbeing can mobilize their social networks more effectively. Longitudinal studies are needed to better understand the directionality. In addition, follow-up qualitative investigations with individuals from each profile could provide valuable insights into the role of social support and other potential protective or risk factors not assessed in the present study. Finally, caregiving can be a chosen or forced role. Self-selection for any volunteering activity, such as being an informal caregiver, has been shown to have positive effects on wellbeing (Charlesworth et al., 2017; Morrow-Howell, 2010).

In this study, we focussed on three domains that previous research has investigated in relation to dementia caregiving: socio-demographic, caregiving, and social support factors. Individual difference variables, however, might also play a significant role in caregivers' psychological wellbeing. For example, in the New Zealand context, Dulin and Dominy (2008) have demonstrated that the mental health of caregivers of people living with dementia was predicted by their attitudes toward the caregiving role. Having a prosocial orientation predicted more positive affect in older caregivers. 
The main strength of the study lies in its person-centred approach, which allowed us to differentiate between vulnerable and healthy groups of dementia caregivers and provide a more comprehensive picture of their different experiences. In addition, the study provides further evidence for the role of social support above and beyond demographic, socioeconomic, and caregiving-related variables. Our study was limited to older caregivers living in New Zealand. The way people experience and cope with being a dementia caregiver can be influenced by social climate, cultural values, or policies around aging, health, and care. It is possible that research conducted in other socio-political and cultural contexts would explore different configurations or identify additional psychological profiles of dementia caregivers. However, our study highlights that by exploring subgroups of individuals with similar psychological profiles, we can gain a better understanding of the heterogeneity of the caregiving experience.

\section{Conclusions}

Although the idea that providing care is not necessarily harmful for wellbeing is not new (Kinney \& Stephens, 1989), research investigating the positive and negative effects of caregiving simultaneously is very limited. We believe that our person-oriented approach to identifying different patterns of psychological functioning and their correlates in dementia caregivers contributes to a better understanding of the mental health impact of caregiving and to the development of tailored interventions. Three distinct psychological profiles emerged based on dementia caregivers' self-reported mental health, life satisfaction, depression symptoms, and quality of life. These profile configurations suggest diversity in not only how individuals appraise their caregiving role but also in the ways caregiving difficulties impact people's mental health and wellbeing. How to provide appropriate care for the growing number of dementia patients has become a key question for policy in countries with ageing populations. Our study highlights that we need to be cautious with one-size-fitsall solutions when tackling the issue of caregiver mental health and wellbeing. 


\section{References}

Alves, S., Teixeira, L., Azevedo, M. J., Duarte, M., \& Paul, C. (2016). Effectiveness of a psychoeducational programme for informal caregivers of older adults. Scandinavian Journal of Caring Sciences, 30(1), 65-73.

Bauer, D. J., \& Curran, P. J. (2004). The integration of continuous and discrete latent variable models: Potential problems and promising opportunities. Psychological Methods, 9(1), 3-29.

Beeson, R., Horton-Deutsch, S., Farran, C., \& Neundorfer, M. (2000). Loneliness and depression in caregivers of persons with Alzheimer's disease or related disorders. Issues in Mental Health Nursing, 21(8), 779-806.

Beinart, N., Weinman, J., Wade, D., \& Brady, R. (2012). Caregiver burden and psychoeducational interventions in Alzheimer's disease: A review. Dementia and Geriatric Cognitive Disorders Extra, 2(1), 638-648.

Charlesworth, G., Sinclair, J. B., Brooks, A., Sullivan, T., Ahmad, S., \& Poland, F. (2017). The impact of volunteering on the volunteer: Findings from a peer support programme for family carers of people with dementia. Health \& Social Care in the Community, 25(2), 548-558.

Clark, S., \& Muthen, B. (2009). Relating latent class analysis results to variables not included in the analysis. Retrieved from www.statmodel.com/download/relatinglca.pdf

Cutrona, C. E., \& Russell, D. W. (1987). The provisions of social relationships and adaptation to stress. Advances in Personal Relationships, 1(1), 37-67.

de Vugt, M. E., \& Verhey, F. R. J. (2013). The impact of early dementia diagnosis and intervention on informal caregivers. Progress in Neurobiology, 110, 54-62.

Dulin, P. L., \& Dominy, J. B. (2008). The influence of feeling positive about helping among dementia caregivers in New Zealand. Dementia, 7(1), 55-69.

Etters, L., Goodall, D., \& Harrison, B. E. (2008). Caregiver burden among dementia patient caregivers: A review of the literature. Journal of the American Academy of Nurse Practitioners, 20(8), 423-428.

Fonareva, I., \& Oken, B. S. (2014). Physiological and functional consequences of caregiving for relatives with dementia. International Psychogeriatrics, 26(5), 725-747.

Gierveld, J. D., van Groenou, M. B., Hoogendoorn, A. W., \& Smit, J. H. (2009). Quality of marriages in later life and emotional and social loneliness. Journals of Gerontology Series B Psychological Sciences and Social Sciences, 64(4), 497-506.

Gitlin, L. N., Belle, S. H., Burgio, L. D., Czaja, S. J., Mahoney, D., Gallagher-Thompson, D., REACH. (2003). Effect of multicomponent interventions on caregiver burden and depression: The REACH multisite initiative at 6-month follow-up. Psychology and Aging, 18(3), 361-374. 
Glymour, M. M., Avendano, M., \& Kawachi, I. (2014). Socioeconomic status and health. In L. F. Berkman, I. Kawachi, \& M. M. Glymour (Eds.), Social epidemiology (2nd ed., p. xvii, 615 pages). New York, NY: Oxford University Press.

Greenwood, N., \& Habibi, R. (2014). Carer mentoring: A mixed methods investigation of a carer mentoring service. International Journal of Nursing Studies, 51(3), 359-369.

Hogstel, M. O., Curry Cox, L., \& Walker, C. (2005). Caring for older adults: The benefits of informal family caregiving. The Journal of Theory Construction \& Testing, 9, 55-60.

Inglehart, R., Basanez, M., Diez-Medrano, J., Halman, L., \& Luijkx, R. (2004). Human beliefs and values: A cross-cultural sourcebook based on the 1999-2002 values surveys. Mexico City, Mexico: Siglo XXI.

Janssen, E. P. C. J., de Vugt, M., Kohler, S., Wolfs, C., Kerpershoek, L., Handels, R. L. H., Verhey, F. R. (2017). Caregiver profiles in dementia related to quality of life, depression and perseverance time in the European Actifcare study: The importance of social health. Aging \& Mental Health, 21(1), 49-57.

Jensen, J., Spittal, M., Crichton, S., Sathiyandra, S., \& Krishnan, V. (2002). Direct measurement of living standards: The New Zealand ELSI scale. Wellington, New Zealand: Ministry of Social Development.

Joling, K. J., van Hout, H. P. J., Schellevis, F. G., van der Horst, H. E., Scheltens, P., Knol, D. L., \& van Marwijk, H. W. J. (2010). Incidence of depression and anxiety in the spouses of patients with dementia: A naturalistic cohort study of recorded morbidity with a 6-year follow-up. American Journal of Geriatric Psychiatry, 18(2), 146-153.

Kinney, J. M., \& Stephens, M. A. P. (1989). Hassles and uplifts of giving care to a family member with dementia. Psychology and Aging, 4(4), 402-408.

Kohout, F. J., Berkman, L. F., Evans, D. A., \& Cornoni-Huntley, J. (1993). Two shorter forms of the CESD (Center for Epidemiological Studies Depression) depression symptoms index. Journal of Aging and Health, 5(2), 179-193.

Kraijo, H., Brouwer, W., de Leeuw, R., Schrijvers, G., \& van Exel, J. (2012). Coping with caring: Profiles of caregiving by informal carers living with a loved one who has dementia. Dementia-International Journal of Social Research and Practice, 11(1), 113-130.

Kramer, B. J. (1997). Gain in the caregiving experience: Where are we? What next? Gerontologist, 37(2), $218-232$.

MacRae, H. (1999). Managing courtesy stigma: The case of Alzheimer's disease. Sociology of Health \& Illness, 21(1), 54-70.

Ministry of Health. (2013). New Zealand framework for dementia care. Wellington, New Zealand: Ministry of Health.

Morrow-Howell, N. (2010). Volunteering in later life: Research frontiers. Journals of Gerontology Series B-Psychological Sciences and Social Sciences, 65(4), 461-469. 
Muthe'n, L., \& Muthe'n, B. (2012). MPLUS (Version 7.1). Los Angeles, CA: Statistical Software.

Pearlin, L. I., Mullan, J. T., Semple, S. J., \& Skaff, M. M. (1990). Caregiving and the stress process - An overview of concepts and their measures. Gerontologist, 30(5), 583-594.

Pinquart, M., \& Sorensen, S. (2004). Associations of caregiver stressors and uplifts with subjective wellbeing and depressive mood: A meta-analytic comparison. Aging \& Mental Health, 8(5), 438-449.

Prince, M., Brycea, R., Albanese, E., Wimo, A., Ribeiro, W., \& Ferri, C. P. (2013). The global prevalence of dementia: A systematic review and metaanalysis. Alzheimer's \& Dementia, 9(1), 63-75.

Raftery, A. E. (1995). Bayesian model selection in social research. Sociological Methodology, 25(25), 111163.

Rozario, P. A., Morrow-Howell, N., \& Hinterlong, J. E. (2004). Role enhancement or role strain Assessing the impact of multiple productive roles on older caregiver well-being. Research on Aging, 26(4), $413-428$.

Sanders, S. (2005). Is the glass half empty or half full? Reflections on strain and gain in caregivers of individuals with Alzheimer's disease. Social Work in Health Care, 40(3), 57-73.

Schulz, R., Burgio, L., Burns, R., Eisdorfer, C., Gallagher-Thompson, D., Gitlin, L. N., \& Mahoney, D. F. (2003). Resources for enhancing Alzheimer's caregiver health (REACH): Overview, sitespecific outcomes, and future directions. Gerontologist, 43(4), 514-520.

Schulz, R., Obrien, A. T., Bookwala, J., \& Fleissner, K. (1995). Psychiatric and physical morbidity effects of dementia caregiving - Prevalence, correlates, and causes. Gerontologist, 35(6), 771-791.

Statisctics New Zealand. (2013). People aged 65p living in New Zealand. Retrieved from www.stats.govt.nz/Census/2013-census/profile-and-summary-reports/quickstats-65-plus.aspx

Tarlow, B. J., Wisniewski, S. R., Belle, S. H., Rubert, M., Ory, M. G., \& Gallagher-Thompson, D. (2004). Positive aspects of caregiving - Contributions of the REACH project to the development of new measures for Alzheimer's caregiving. Research on Aging, 26(4), 429-453.

Towers, A., Stevenson, B., Breheny, M., \& Allen, J. (2016). Health, work and retirement longitudinal study. In N. Pahana (Ed.), The encyclopaedia of geropsychology. (pp. 977-981). Singapore: Springer.

Vellone, E., Fida, R., Cocchieri, A., Sili, A., Piras, G., \& Alvaro, R. (2011). Positive and negative impact of caregiving to older adults: A structural equation model. Professioni Infermieristiche, 64(4), 237-248.

Vitaliano, P. P., Murphy, M., Young, H. M., Echeverria, D., \& Borson, S. (2011). Does caring for a spouse with dementia promote cognitive decline? A hypothesis and proposed mechanisms. Journal of the American Geriatrics Society, 59(5), 900-908.

Ware, J. E., Keller, S. D., \& Kosinski, M. (1998). SF-12: How to ccore the SF-12 physcial and mental health summary scales. QualityMetric Incorporated. 
Wenger, G. C. (1991). A network typology - From theory to practice. Journal of Aging Studies, 5(2), 147162.

Wennberg, A., Dye, C., Streetman-Loy, B., \& Pham, H. (2015). Alzheimer's patient familial caregivers: A review of burden and interventions. Health \& Social Work, 40(4), 162-169.

Werner, P., Mittelman, M. S., Goldstein, D., \& Heinik, J. (2012). Family stigma and caregiver burden in Alzheimer's disease. Gerontologist, 52(1), 89-97. DOI:10.1093/geront/gnr117.

Wiggins, R. D., Netuveli, G., Hyde, M., Higgs, P., \& Blane, D. (2008). The evaluation of a selfenumerated scale of quality of life (CASP-19) in the context of research on ageing: A combination of exploratory and confirmatory approaches. Social Indicators Research, 89(1), 61-77.

Wolff, J. L., \& Kasper, J. D. (2006). Caregivers of frail elders: Updating a national profile. Gerontologist, 46(3), 344-356.

Zanetti, O., Frisoni, G. B., Bianchetti, A., Tamanza, G., Cigoli, V., \& Trabucchi, M. (1998). Depressive symptoms of Alzheimer caregivers are mainly due to personal rather than patient factors. International Journal of Geriatric Psychiatry, 13(6), 358-367.

\subsubsection{Demencia és társadalmi fenntarthatóság ${ }^{29}$}

\section{Absztrakt}

A demencia az önellátóképesség teljes elvesztéséhez vezető tünetegyüttes, amely az elöregedő társadalmakban, így Magyarországon is egyre több személyt érint. Tekintettel arra, hogy nem egy gyógyítható betegségről van szó, így az érintettekről való gondoskodás, az ellátás elsősorban nem az egészségügyi ellátórendszer feladata, sokkal inkább a szociális ellátórendszer és a családok a feladatok, terhek viselői. Mindez a különböző ellátási formákra eső költséghányadokban is megmutatkozik. A társadalom egésze szempontjából azonban nem csupán a gazdasági tényezők relevánsak, hanem szerteágazó problémákat vet fel a demencia egyre nagyobb arányú megjelenése. A demencia, ahogy más neurodegeneratív kórképek jelentette kihívás - bár látszólag csak egy-egy családot érint - társadalmi szintü, amelynek kezelésére számos ország már akciótervet fogalmazott meg, sőt akár már az első programok eredményeit is értékelték. Az egyéni és társadalmi jóllét fenntartásának elengedhetetlen része egy-egy hátrányt

\footnotetext{
${ }^{29}$ BCE GDI kérése alapján a 3.2.3 fejezet a következő publikáció szó szerinti szövegét tartalmazza:
} Fekete, M. (2019b). Demencia és társadalmi fenntarthatóság. Esély, 30 (2), 31-53. 
szenvedő közösség problémájának tapasztalatokra épülő, rendszerbe illeszkedő kezelése, különösen, ha az generációkon átívelő hatású, ahogyan az a demencia esetén.

\section{Bevezetés}

A demencia egy tünetegyüttes, hátterében többféle betegség, patológiás folyamat állhat. Legismertebb eleme a feledékenység, de valójában a gondolkodási funkció komplex zavaráról van szó, ami fokozatosan vezet a döntésképesség, az ítéletalkotás, a figyelem, a tanulási képesség zavara, valamint a viselkedés és a személyiség kóros megváltozása, majd a fizikai hanyatlás miatt az önálló életvitel akadályozottságához, végül pedig az önellátóképesség teljes elvesztéséhez. Az esetek legnagyobb részéért az Alzheimer-kór a felelős, de az agyi érkatasztrófák vagy krónikusan zajló agyi vérellátási zavarok is gyakran állnak a demencia kialakulásának hátterében, illetve más neurodegeneratív (idegrendszeri leépüléssel jellemezhető) kórfolyamathoz is társulhat (pl. Parkinsonkórhoz), továbbá számos más eredete is lehet. Ahogy azonban a mentális zavarok nemzetközi klasszifikációs rendszerének (DSM - Diagnostic and Statistical Manual of Mental Disorders) ${ }^{30}$ a 2013-ban megjelent ötödik verziójában is tetten érhető, a tünetekre és azok súlyosságának mértékére fókuszál a klinikai megközelítés az etiológia mellett. A demencia a legújabb osztályozás szerint a „neurokognitív rendellenességek” elnevezéssel illetett új csoportba tartozik, annak is a súlyos jelzővel felruházott fokozatába, ugyanakkor egy enyhe megjelölésű csoport is nevesítésre került, amely kifejezi, hogy a demencia nem egy előzmény nélkül megjelenő tünetegyüttes (American Psychiatric Association, 2013). A klinikai nevezéktan változása tükrözi az Amerikai Pszichiátriai Társaság azon törekvését, hogy megjelenítsék, hogy egyes kórképekben a tünetek, a stádiumok egy súlyossági spektrumon helyezkednek el, ahol a súlyossági szintek közötti átmenetek nem élesek, ugyanakkor az állapot súlyosságának mértéke nagy jelentőségű a szükséges ellátás meghatározásában. Kognitív zavarok esetén az enyhe formánál a mielőbbi felismerés, ezzel az esetleg kezelhető ok azonosítása a cél, a súlyos formánál pedig a gondozási szükséglet felmérése. A demencia, illetve a kognitív zavar elörehaladása, súlyosbodása során míg kezdetben akár önkéntelen kompenzációs trükkökkel a mindennapi életvitel fenntartható, addig később a társuló viselkedési,

\footnotetext{
${ }^{30}$ https://www.psychiatry.org/psychiatrists/practice/dsm/educational-resources/dsm-5-fact-sheets
} (2019.03.26) 
pszichés és testi tünetek, a fizikai állapot romlása az önellátási képesség elvesztéséhez vezetnek (Gustafson, 1996).

A demencia megjelenésére az életkor növekedésével egyre nagyobb esély van, így az öregedő társadalmaknak - így hazánknak is - a demenciával élők számának emelkedésével kell számolnia. A kognitív funkció zavarával járó állapot az időskorúak egyéb funkcionális - érzékelési és mozgásbeli - korlátozottságaival szemben segédeszközökkel nem korrigálható, ezért a kieső, pótlásra vagy legalábbis támogatásra szoruló funkciók a gondozási igény fokozatos növekedéséhez vezetnek. Mindez komoly kihívás a társadalmi fenntarthatóság szempontjából, mivel mind a demenciával élők, mind az őket gondozó családtagok - informális ápolók - életminőségének megőrzése jelentős nehézségekbe ütközik.

A társadalmak a demenciával kapcsolatban egy elöre látható, becsülhető mértékü és következményü kihívással kerülnek szembe. A társadalom elöregedésének hazánkhoz hasonló mértékével jellemezhető országok velünk szemben többnyire rendelkeznek a probléma kezelését célul kitűző stratégiával. Az e vonatkozásban élenjáró Franciaországban, amely 2001-ben hirdette meg első „Alzheimer Tervét”, akkoriban a 65 év feletti lakosság aránya $16 \%{ }^{31}$ volt. Ma Magyarországon a 65 éves életkort betöltöttek a társadalom 19\%-át teszik ki.

A hadvezetésböl örökölt stratégia szóval azokat a cselekvési terveket illetik, melyeket egy kihívással való megbirkózásra dolgoztak ki. A cselekvési tervek jellemzője a kutatásokkal is alátámasztott helyzetelemzés, mérföldkövek meghatározása és az elért eredmények követése, mérése. A hiteles, meggyőző elméleti háttér kidolgozottsága, valamint a szakterületek közötti együttműködés, folyamatos konzultáció és a konszenzus alapján született döntések vezethetnek eredményhez. A demencia esetén az egészségügyi és szociális terület mellett a társadalmi és gazdasági megfontolásoknak is jelentős szerepet kell kapniuk, annak érdekében, hogy a társadalmi fenntarthatóság céljai is érvényesüljenek.

\footnotetext{
${ }^{31}$ Forrás: OECD (2019), Elderly population (indicator). doi: 10.1787/8d805ea1 -en (2019.03.01)
} 
A demencia demográfiai háttere

A demencia az időskorúakat érintő más funkcionális korlátozottságot okozó folyamatokkal együtt az életkor növekedésével egyre többeket érint. Egyes kutatók, más tényezők szerepét sem kizárva, a demenciát tartják az időskori önellátóképesség elvesztésében az egyik leggyakoribb tényezőnek (Wübker, 2015). Az öregedő populációjú országoknak, így Magyarországnak is kiemelten kell/kellene az idősek igényeit követnie, mivel arányuk fokozatosan emelkedik a társadalmon belül. A társadalom egészének érintettsége nem csak a generációk természetes kapcsolódásából, a családi kötelékekből adódik, hanem azokból az új, társadalmi szinten megoldandó kihívásokból is, amelyeket a korcsoportok arányainak drasztikus megváltozása okoz.

Az Európai Bizottság a társadalom elöregedésének problémáját projekciók szintjén is tárgyaló legutolsó, 2018-ban megjelent tanulmánya az Eurostat 2015-ben készített

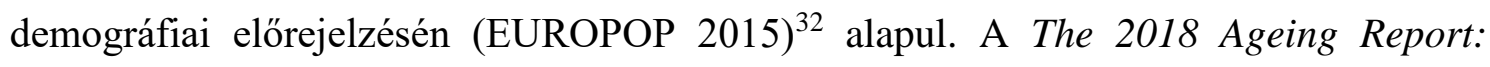
Economic and budgetary projections for the 28 EU Member States (2016-2070) 28 Európai Uniós tagállamra vonatkozóan 2070-ig fogalmaz meg - a demográfiai trendekre alapozva - gazdasági, költségvetési előrejelzéseket öt területet érintően. Ezek a nyugdíjellátás, az egészségügyi ellátás, a hosszú tartamú ápolás (long-term care, LTC), az oktatás és a munkanélküli ellátás témái, melyek a társadalmi fenntarthatósághoz is közvetlenül vagy közvetve kapcsolódnak. A demencia problémájához ezek közül közvetlenül kapcsolódik az egészségügyi ellátás és a hosszú tartamú ápolás kérdése, tekintettel arra, hogy egy folyamatosan romló, gyógyszeres kezeléssel csupán korlátozottan befolyásolható, rendszeres ellenőrzést, követést igénylő állapotról van szó, akár évtizedes tartamú ápolás válhat szükségessé. Ugyanakkor a demenciának a társadalom mikroközösségeit, a családokat is komolyan érintő volta miatt a demenciával élő családtagról gondoskodó, munkavállaló korú vagy akár már nyugellátásban részesülők anyagi életkörülményei és életminősége is jelentős változás lehetőségének vannak kitéve.

Magyarország lakosságszámát a legoptimistább előrejelzések is csökkenőként írják le: 2040-re 9,5 millió alá, 2070-re várhatóan 9 millió alá csökken a populáció. A három meghatározó tényező - fertilitási ráta, migráció, várható élettartam - eredőjeként születik

\footnotetext{
${ }^{32} \mathrm{https} / / /$ ec.europa.eu/eurostat/web/population-demography-migration-projections/populationprojections-data (2019.02.25.)
} 
meg a lakosságszámra vonatkozó becslés. Bár a fertilitási ráta határozott növekedésével számolnak, de az így sem fogja várhatóan elérni azt a szintet, amely a populáció szinten tartásához minimálisan szükséges lenne. A migrációból eredő népességnövekedést hazánkban csekély mértékünek prognosztizálják. A várható élettartam emelkedése jelentősnek becsült: az elkövetkező fél évszázad alatt, 2070-ig a férfiak a születésükkor várható élettartamban mintegy 11 éves, a nők 9 év növekedést remélhetnek. Külön az idősebbek várható élettartamára is kitérnek, és megvizsgálták, hogy a 65 évesek mennyi életévre számíthatnak még. Ezen a téren is kifejezett növekedés várható, mivel míg napjainkban egy nyugdíjkorhatárt elérö férfi még 14,9 évnyi egy nő pedig 18,7 évnyi további élettartamra számíthat, addig 2070-ben már további 22, illetve több mint 25 évet élnek majd átlagosan ezen korosztály tagjai.

A valódi demográfiai kihívást tehát Magyarországon is - az Európai Unió több országához hasonlóan - a koreloszlás jelentős megváltozása okozza majd (Ábra 1.).

Ábra 1. Magyarország lakosságának korcsoportonkénti alakulása 2016-2070

(EUROSTAT - EUROPOP 2015 alapján, saját feldolgozás)

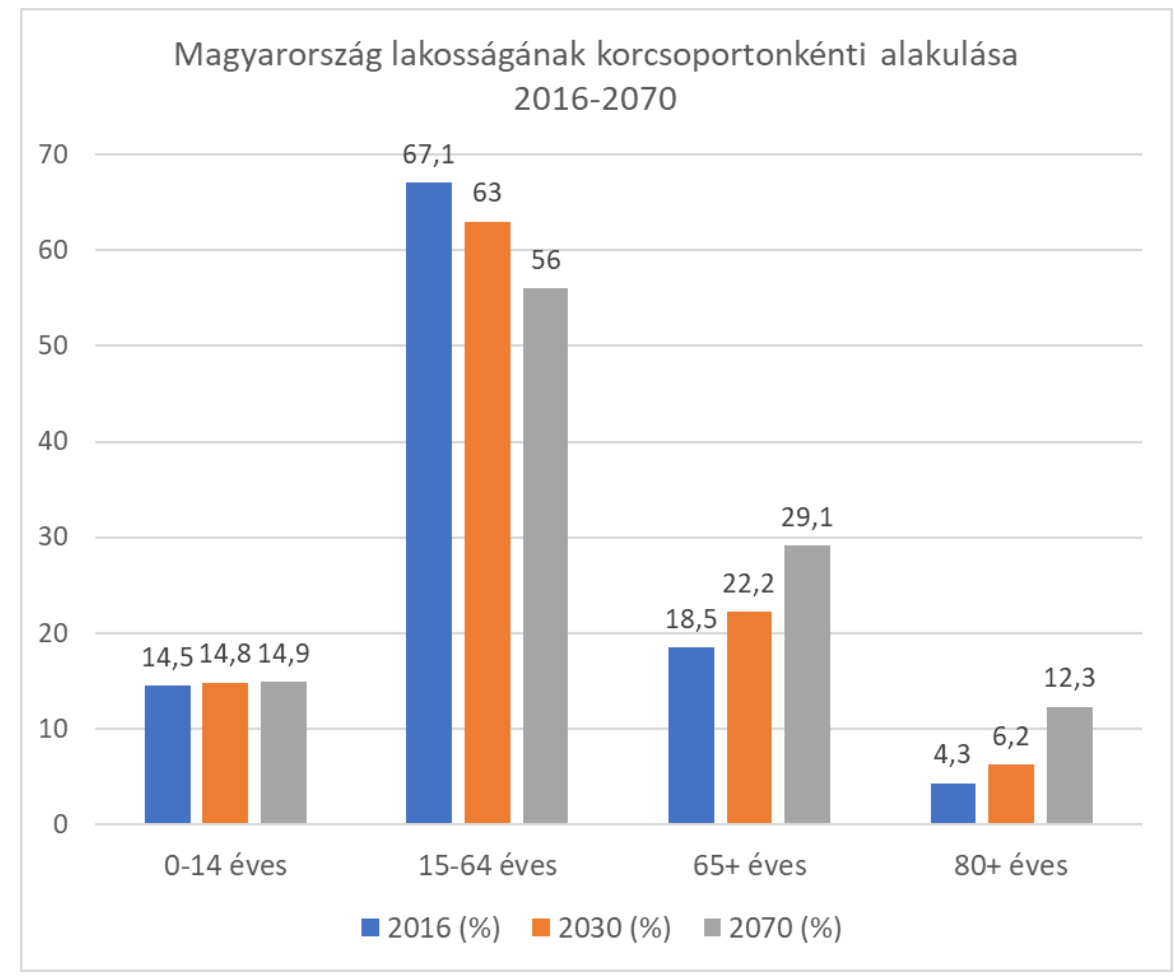

A tendencia tehát az aktív korúak arányának jelentős mértékü csökkenése, mellyel szemben az időskorúak arányának növekedése áll. A fiatal korosztály aránya még a növekvő fertilitási ráta mellett is stagnálónak várható. A demencia szempontjából az a 
részadat is releváns, miszerint a 80 év felettiek aránya is nő 4,3\%-ról közel a háromszorosára, 12,3\%-ra, mivel körükben a demencia elöfordulási aránya már akár a 10\%-ot is meghaladhatja (Prince, 2013).

A demográfiai folyamatok gazdasági és társadalmi következményeinek egyik látványos előrevetítője a különböző életkori csoportok nagyságának egymáshoz viszonyulása. Az idős népesség függőségi vagy eltartottsági rátája a 65 évesek és idősebbek és az „őket eltartó” úgynevezett aktív vagy munkaképes korúak (15-64 éves) arányát mutatja meg. Fontos információt nyújt ez az arányszám arról, hogy a társadalmi ellátó rendszerek müködése fenntartható-e, mekkora terhet ró az időskorúak „eltartása” a potenciálisan munkát vállaló korosztályra. Az Európai Bizottság előrejelzése alapján Magyarország vonatkozásában ez a függés 27,5\%-ról 52\%-ra nő, azaz közel megduplázódik. A nagyon idős (80 év feletti) népesség függőségi rátája - azaz arányuk az aktív korúakhoz (15-64 éves) képest - rávilágít arra, hogy a még inkább gondoskodásra, még több formális és informális ápolási-gondozási szükséglettel bíró korosztály milyen arányú lesz az ezt leginkább biztosítani képes korosztályhoz képest. Igen elgondolkodtató a 2016-os helyzetet jellemző 6,4\% -os arány 2070-re előrevetített növekedése 22\%-ra. A demencia problémája felől szemlélve a korszerkezet megjósolható változását, a „függőség” vonatkozásában két szempontból is lehet vizsgálni azt. Egyrészt a betegséggel érintett személy nem lesz aktív jövedelemtermelő még akkor sem, ha életkorát tekintve az aktív korúak csoportjába tartozik. Az így kieső jövedelemtermelés azonban gyakran nem csupán a betegséggel érintett részéröl jelentkezik, hanem az ő ellátásában résztvevő aktívkorú hozzátartozó - férj, feleség vagy felnőtt gyermek - munkavállalási képességének nehézsége miatt is, tekintettel arra, hogy a korosztály számára az állapotuk alapján is többnyire a legjobb ellátási forma - demenciával élők nappali ellátása elérhetósége szórványos, így a családtagok kényszerülnek megoldást találni a felügyeletre, gondoskodásra. Nem ritka, hogy az idősebb generáció, tehát a már nyugellátásban részesülő családtag vállalja a gondozás - még nem fizikai terhet jelentő biztosítását, ilyenkor azonban az említett „függőség” éppen ellentétes irányúra vált, ráadásul még kevésbé merül fel az ápolás pénzbeli megváltásának kötelessége, a nyugdíjellátásban részesülő szabadidejének megváltása, holott egy állami feladatot vált ki tevékenységével. 
Az informális ápolás makrogazdasági megítélésének torz voltára nem csak a személyes történetek világítanak rá. A GDP ${ }^{33}$ „könyörtelenségének”, hiányosságának egyik példájaként az informális ápolás is felhozható (Kerekes, 2009), mivel ahogy a család számára felbecsülhetetlen értékü háztartási tevékenységek - gyermeknevelés, mosás, fözés, takarítás stb. - nem piaci alapon történnek, elvégzésükért nem jár jövedelem, így nem képezik a GDP kalkulációjának részét. Így ez a szintén többnyire megfizetetlen, a társadalom számára ugyanakkor kiemelten fontos, tehermentesítő, önkéntes tevékenység sem jelenik meg ebben a makrogazdasági mutatóban.

\section{Az ellátórendszer alkalmazkodási kényszere}

A demencia vagy az enyhe kognitív zavar, illetve más neurodegeneratív kórképek előfordulásának az életkor növekedését kísérő gyakoribb kialakulása csupán néhány ok arra, hogy az ellátórendszereknek miért kell új kihívásoknak megfelelniük a társadalom elöregedése miatt. A demenciával élők számára vonatkozó pontos adat nem áll rendelkezésre, ugyanis még a fejlett országokban sem tekinthető a korai diagnózis minden érintett számára elérhetőnek. Egy átfogó vizsgálat, részben kvantitatív metaanalízisen alapuló becslése szerint Európában a 60 év felettiek 5,7-6,92 százaléka lehet demenciával érintett (Prince, 2013), úgy, hogy ezen belül a 80 év felettiek érintettsége már 10\%-ot meghaladó, 90 év felett a férfiak legalább harmada, a nők közel fele él kognitív zavarral. Az össz-európai és a régiós becslésekből következtetve Magyarországon a demenciával élők száma legalább 150 ezer lehet. Az Alzheimer Europe ${ }^{34}$ ernyőszervezet a 2013-ban kiadott riportjában (Alzheimer Europe, 2013) közölt utoljára konkrét, országokra vonatkozó prevalencia adatokat, amely szintén 150 ezerhez közelítő létszámot nevez meg. Hazai szakértő 150-300 ezer demenciával élővel számol (Kovács, 2016), tehát a legalább 150 ezres szám megalapozottnak, több irányból is megerősítettnek tekinthető.

Megjegyzendő, hogy az Alzheimer Europe ernyőszervezet legfrissebb, Dementia in Europe Yearbook 2018 - Comparison of national dementia strategies in Europe címmel megjelent évkönyvében (Alzheimer Europe, 2018) a prevalenciával kapcsolatban azt fogalmazzák meg, hogy a demencia stratégiával rendelkező tagországok jelentős részében a stratégia része, és az első feladatok között szerepel a prevalencia

\footnotetext{
${ }^{33}$ GDP - Gross Domestic Product $=$ Bruttó hazai termék

34 http://www.alzheimer-europe.org/
} 
meghatározását célzó kutatások elvégzése. A tünetegyüttes előfordulásának valódi mértéke és a probléma jelentősége még mindig becsült, és feltehetően alulbecsült.

Az idősödés, az ezzel járó funkciócsökkenés az egészségügyi ellátás akut-ellátáshangsúlyú müködését a krónikus ellátás irányába kell egyrészt, hogy terelje, másrészt a szociális ellátórendszerrel való szorosabb együttmüködést kell, hogy kikényszerítse. Magyarországnak nem kell az idősödéssel kapcsolatos egészségpolitikai elvek, cselekvési tervek kidolgozásakor alapjaiban új dolgokat kitalálnia, hiszen építhet a demográfiai trendek értékelésében, illetve a cselekvési szükségszerüség felismerésében előttünk járók vívmányaira. Ésszerü adaptációval hasznosíthatóak a máshol megvalósult, bejáratott jó gyakorlatok, az igényekhez igazított rendszerek müködésének tapasztalatai. Példaként a „legöregebb országként” ismert Japán az 1980-as évek végére szembesült a második világháború után indult demográfiai folyamatok eredményével, a növekvő arányú időskorúak ellátásának problémájával. Az ápolást nyújtó intézményi kapacitás növelése mellett a finanszírozás fedezetének megteremtése érdekében 2000-ben kötelező ápolás-biztosítást vezettek be (Campbell, 2000a), melyhez mintául Németország 1994ben bevezetett modellje és a skandináv ellátási struktúra szolgált. Mind Németországban, mind Japánban a speciális társadalombiztosítás elindításakor a 65 év felettiek aránya nem érte el a 16\%-ot (Campbell, 2010b). Magyarországon a korcsoport aránya jelenleg 19\%.

Az ellátórendszereknek tehát új kihívások elé kell nézniük az idősek arányának és a várható élettartamnak a növekedése miatt. Az ellátást indikáló betegségek, állapotok között nő az idősebb korosztályra jellemzők aránya, mint például a combnyaktörés, a daganatos megbetegedések, az agyi történés (sztrók) vagy a demencia (Rechel, 2013). Mindezek miatt az ellátás struktúrájának és finanszírozásának módosítása is szükségessé válik. Ugyanakkor az nem egyértelmü, hogy valójában miért vezet egészségügyi kiadásnövekedéshez a várható élettartam növekedése. A Lancet elöbb idézett tanulmánya (Rechel, 2013) három elméletet is bemutat, melyek eltérően ítélik meg, hogy a várható élettartam megnövekedése hogyan hat a megbetegedés, valamint a halálozás alakulására, az egészségben vagy a betegségben eltöltött életévek száma növekedik-e, vagy a krónikus betegségek szükségszerü előfordulása mellett akár több életévet is jobb életminőségben töltenek el az idősek. Különböző vizsgálatok különböző elméletek igazát erősítik, ezek hátterében a kiválasztott változók és mérési módszerek eltérése áll. Választ remélhetünk 
az idősek körében végzett panelvizsgálatokból (pl. $\mathrm{ELSA}^{35}, \mathrm{SHARE}^{36}, \mathrm{TILDA}^{37}$ ), ahol a több hullámban végzett adatgyüjtés lehetőséget biztosít akár a fenti kérdések megválaszolására is.

Ahogy a morbiditás alakulásának meghatározásához nincs egyértelmü koncepció, úgy a társadalom elöregedésének az egészségügyi kiadásokra gyakorolt hatása sem egyértelmü. De Meijer és munkatársai (2013) összegző elemzése szerint a társadalom elöregedése jelentős részben indirekt módon vezet az egészségügyi kiadások növekedéséhez, úgynevezett társadalmi tényezőkön keresztül, mint a nemzeti jövedelem, az orvosi technológia, az árak és bérek növekedése. Ugyanakkor a költségek növekedéséhez egyfajta árfelhajtó módon - az ellátásért való nagyobb fizetési hajlandóság is hozzájárulhat, amely nem feltétlenül probléma, ha ez a szolidaritás elvén alapul és az egészségi állapot javítását szolgálja. Szintén kifejezetten kedvező lehet a technológia fejlödése - még a költségek növelése árán is -, ha annak eredményeként az időskorúak funkcionális korlátozottságait sikerül mérsékelni vagy megszüntetni, és ennek következményeként egyrészt az alacsonyabb költségü otthoni körülmények közötti ápolás időtartama megnyújtható, de akár a munkaerőpiaci aktivitás is kitolható.

Az egészségügyi költségek alakulására direkt hatást az akut ellátás oldalán mérsékelten gyakorol a társadalom elöregedése, hatása a krónikus ellátás tekintetében jelentősebb. A krónikus ellátás, tartós ápolás iránti növekvő igény amiatt is vezet a költségek emelkedéséhez, mivel munka-intenzív szolgáltatás, az egyre fejlődő technológiával amely egyaránt vezet költségnövekedéshez, ugyanakkor költségcsökkentő hatása is lehet - kevésbé kiváltható, így erősen meghatározza az ellátás díját a munkaerő bére, amely bizonyosan növekedni fog.

A szociális szolgáltatások költségei a fenti logika mentén szintén leginkább munkaintenzív voltukból, valamint az ellátási szükséglet mennyiségének megnövekedéséből adódnak. Az alapellátási tevékenységek közül a demenciával élők többet is csak informális ápoló aktív közremüködésével tudnak igénybe venni - pl. étkeztetés vagy házi segítségnyújtás. A nappali ellátás egy kivételesen jó lehetőség lenne a demenciával élők hozzátartozóinak, informális ápolóiknak a részleges tehermentesítésére, munkaerő-piaci

\footnotetext{
${ }^{35}$ English Longitudinal Study of Ageing

${ }^{36}$ Survey of Health, Ageing and Retirement in Europe

${ }^{37}$ The Irish Longitudinal Study on Ageing
} 
vagy közösségi aktivitásuk fenntartására, megbetegedésük, kiégésük megelőzésére. A demenciával élőkkel való foglalkozásra szakosodott - demenciával élők nappali ellátását biztosító - szolgáltatás több engedélyezett férőhelyet biztosító megjelenése elött az akadály a speciális szakember iránti igény, illetve az idősek nappali ellátásához képest kifejezetten magas szakképzett ellátó / ellátotti arány szükségessége, továbbá a megfelelő környezeti feltételek és a megfelelö finanszírozási háttér hiánya. A szociális szakellátások közül a demenciával élök és hozzátartozóik - többnyire az informális gondozók kimerülése után - a tartós ápolást, gondozást nyújtó intézményi elhelyezést igénylik, amelynél a magas munkaintenzitású ellátás, komolyabb infrastruktúra igény vezet a költségek emelkedéséhez. Az ellátáshoz való hozzáférést egy sajátos körülmény is befolyásolja a szociális területen, miszerint gyakran nem igényvezérelt a szolgáltatás kiépülése, hanem a működtetők, fenntartók (önkormányzatok, egyházak, civil szervezetek) határozzák meg a kapacitást, majd igyekeznek betölteni a férőhelyeket a gazdaságos müködés érdekében (Goldmann-Gyetvai-Mester, 2016).

A demencia gazdasági hatásai

A demencia egyrészt a társadalmi szolidaritás elvén alapuló ellátásokra mutatkozó igény növekedése, másrészt a betegséggel élőket és családjaikat érő anyagi veszteségek miatt bír figyelemreméltó gazdasági hatással. Előbbi az ellátást nyújtó intézmények, szolgálatok fenntartása, müködtetése, szakfeladatok ellátása kapcsán jelentkező költségek növekedésével jár, míg a demenciával élők és az őket gondozó családtagok bevételeik csökkenésével és - többek között - anyagi terheik növekedésével számolhatnak.

Társadalmi fenntarthatóság szempontjából mindkét megközelítés releváns, hiszen az egyéni jól-létnek az életminőség szubjektív megítélésén túl az anyagi életkörülmények is meghatározói (OECD, 2011). A vázolt teljes költségspektrum pedig azért mérvadó, mivel azt a társadalom egészének kell fedeznie éppen a szolidaritás elve alapján. A kívánatos, preferált ellátási forma meghatározásában, mint például, hogy a drágább intézményi vagy az alacsonyabb költségszintű saját otthonban történő gondoskodás valósul-e meg, gondos mérlegelésnek, pontos kalkuláción alapuló szakpolitikai döntésnek kellene szerepet játszania az egyéni igények és képességek mellett. Egy ellátási struktúrán belül a központi hatalom, az irányadó szakpolitika által, szabályozókon keresztül megvalósított rendnek 
tükröznie kell a gazdasági racionalitás érvényesülését is, melyhez a költségparaméterek ismerete elengedhetetlen, és így nyernek értelmet például a betegségteher és költséghatékonyság fogalmak (Gulácsi, 2012).

A költségeket „direkt” és „indirekt” - vagy más terminus szerint „közvetlen” és „közvetett” - típusra oszthatjuk aszerint, hogy azok mennyire mérhetőek, számíthatóak közvetlenül. A direkt költségek jellemzően a formális, avagy hivatalos ellátási rendszerekhez, tehát az egészségügyi és szociális ellátáshoz kapcsolódnak, meghatározásuk többnyire a hivatalos finanszírozáson alapul, tehát kalkulálható. Ezen belül tételesen vizsgálható a különböző progresszivitási szinten történő egészségügyi alapellátás, járó- és fekvőbeteg ellátáshoz -, valamint a szociális ellátás különböző típusaihoz - alap-, szakosított vagy intézményi ellátáshoz - kapcsolódó költségek alakulása. Az indirekt költségek ugyanakkor az informális, tehát a nem hivatalosan szervezett gondoskodáshoz kapcsolódnak, így meghatározásuk viszonyításon vagy becslésen alapul, illetve az is befolyásolja a mértékét, hogy mennyire szélesen értelmezik a kapcsolható tevékenységeket.

Demenciával élők esetén a direkt egészségügyi költségek az egészségügyi ellátórendszer használatához kapcsolódnak, így a fekvő- vagy a járó-beteg szakellátásra fordított kiadások és a gyógyszerköltségek jelentik a fö összetevőket. Tekintettel arra, hogy a demencia kezelésében jelenleg nincs olyan hatóanyag mely új, innovatív készítmény alapjául szolgálna, így a demenciával élők gyógyszeres kezelése összességében nem tekinthető jelentős kiadási tényezőnek, még akkor sem, ha a demencia más neurodegeneratív kórkép tüneteként jelentkezik. A demencia, mint vezető diagnózis a fekvő- és járóbeteg ellátás területén sem eredményez kiemelkedő költséget, tekintettel egyrészt arra, hogy a feltételezhetően érintett betegek töredéke rendelkezik diagnózissal, illetve a kóros állapot felismerése után sem feltétlenül történnek rendszeres kontroll vizsgálatok, gyakran a „gyógyíthatatlan” címke miatt a hozzátartozók nem veszik igénybe az egészségügyi ellátórendszert.

A demenciához kapcsolódó direkt költségek jelentősebb részét a direkt szociális ellátási költségek teszik ki. Ezek a szociális ellátórendszer által biztosított formális ellátások költségeit foglalják magukba, mint az étkeztetési szolgálgatás, a transzport, a lakó- vagy ápoló-otthon költségei. Egyes, jellemzően a háziápolás keretében nyújtott szolgáltatások finanszírozása hazánkban az egészségbiztosítási alapból történik, míg más országokban 
ez az ellátási forma a direkt szociális ellátás költségeit gyarapítja, ami a nemzetközi összehasonlítást problémássá teszi. Hasonlóan változó a gondozási, ápolási intézményekben az orvosi ellátás költségének besorolása. A demenciával élők ellátása tipikus példája annak, hogy az egészségügyi és szociális ellátás - ahogy a rendszerek kialakulásának eredete, a szolidaritási alapú társadalombiztosítás egészségügyi ellátás biztosításán túlmutató volta is igazolja ezt - gyakran nem szétválasztható, nem csak finanszírozási, de intézményi szinten sem. Igaz ez az otthoni ellátás és az intézményben történő ellátás vonatkozásában is.

Az indirekt költségek számbavételének szükségességét mára számos vizsgálat igazolta (Krol, 2015; Jönsson, 2009). Az indirekt költségek jelentős része az informális, rendszerint családtag ismerős, vagy más nem szakértő által nyújtott ápolási, gondozási tevékenységből adódik. Az öregedő társadalmak jóléti rendszereinek egyre számottevőbb „kisegítője” ez az ellátási forma, melyben a költségek indirekt módon tevődnek össze az alábbiakból:

- a gondozást végző személy meg nem fizetett munkája - időráfordítás alapú megközelítés: ami alatt nem tud kereső tevékenységet folytatni; nem tud más meg nem fizetett munkát (pl. háztartásvezetést) végezni; de ide tartozik a szabadidő megváltásának költsége is;

- a gondozást végző személy önkéntes ápolói tevékenységéből adódó egészségkárosodás, annak ellátása, vagy csupán az egészségi állapotának megőrzésére irányuló egészségügyi kiadások;

- a gondozással kapcsolatban felmerülő közvetlen és közvetett kiadások, melyek az ellátás eszközeinek beszerzésétől, a fogyó, tehát rendszeresen pótlandó anyagok, eszközök, vagy akár a megfelelő, speciális étkezés biztosításának költségei, illetve bármely nem hivatalos kiadás, melyeknél a „szükségesség” akár nem is mérlegelt, de a kiadás megtörtént.

Az egyéni szinten jelentkező indirekt költségek mellett a társadalmi szinten jelentkező költségek is jelentősek a demenciával élőket ápoló aktív korúak munkából való kiesése miatt, mivel a meg nem szerzett jövedelem az államnak meg nem fizetett adót és járulékot jelent. 
A költségek meghatározásának metódusa tehát többféle lehet, mivel alapulhat a tevékenységre fordított idő mérésén, de nem közömbös a teher becslésében a gondozási tevékenység intenzitása, sőt a pszichés megterhelés mértéke sem. A gondozási intenzitás a felügyeleti jellegű, ,kísérésként” megélt gondoskodástól az aktívabb, ügyintézésben történő segédkezésen át a személyes, mindennapi szükségletek kielégítésének támogatásáig, ápolási szintű tevékenység végzésig terjedhet. A demenciával élök ápolóit érő stressz mechanizmusára kidolgozott elmélet ezekkel, mint nem befolyásolható tényezőkkel, adottságokkal számol, a betegtől származó stresszornak tekinti (Ábra 2.) (Pearlin,1990).

2. Ábra: Az ápolási folyamat okozta stressz összetevői (Forrás: saját szerkesztés, Pearlin 1990. alapján)

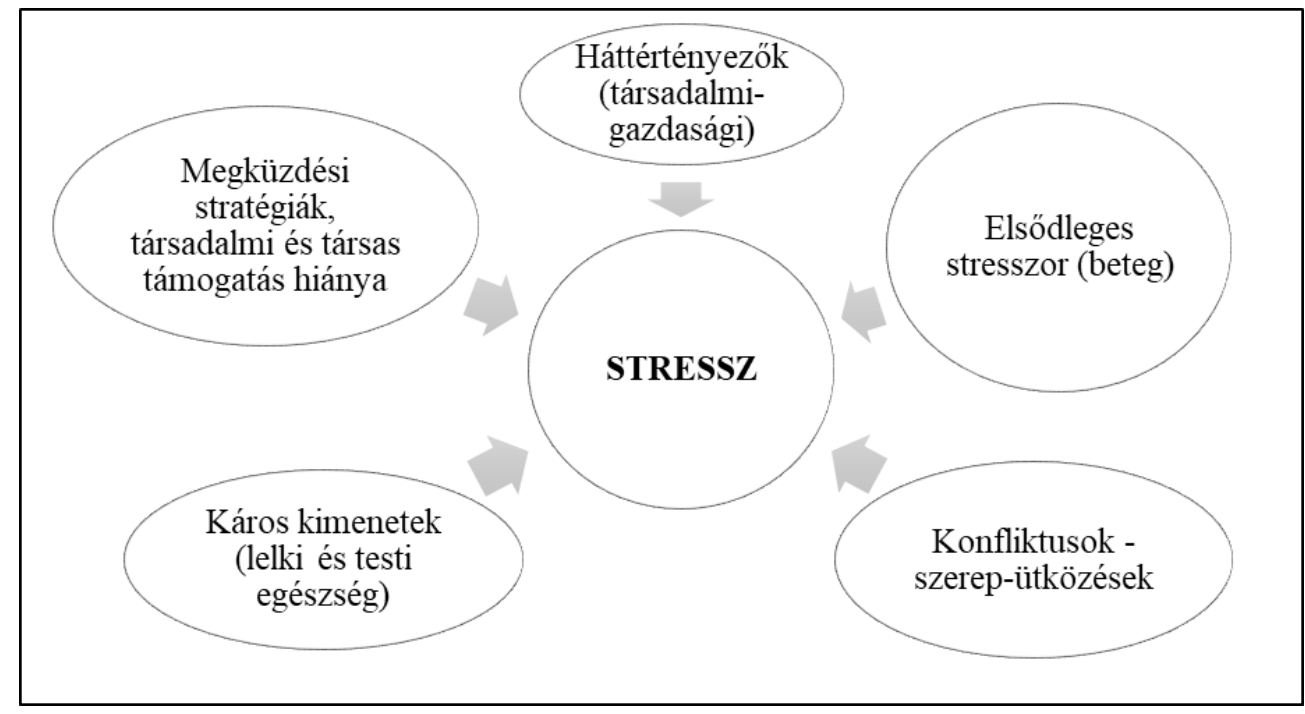

Az informális ellátás jelentős, számbavételre érdemes költségtényező voltát igazoló kutatás (Krol, 2015) is kitért arra, hogy a gondozót nem csak anyagi, hanem testi és mentális egészségi teher, károsodás is érheti. Azt is megállapították, hogy a progresszív, tehát fokozatos rosszabbodással jellemzett neurodegeneratív - idegrendszeri leépüléssel - járó kórképek (mint amilyen a demencia tünetegyütteséhez vezető kórképek többsége) amellett, hogy az ellátási szükséglet időről időre történő növekedés jellemző rájuk, ráadásul a gondozási folyamat nem ritkán évtizedes tartamú, így a többi - például daganatos - betegséggel szemben különösen nagy kihívást jelentő feladattá teszi az informális ápolást.

Az informális ápolás a jóléti rendszerek kiegészítője, müködését szándék és szükség is jellemzi. Mára igazolt, hogy az informális ellátás jelentősen hozzájárul a társadalmi 
jóléthez (Krol, 2015). Ismerve a demenciával élőkről gondoskodókat érő hatásokat, a jóléti rendszereknek ki kell/kellene terjedniük az ő védelmükre is. Tekintettel arra, hogy a demenciával élők - amennyiben nem tartós intézményi ellátásban részesülnek - egy vagy több informális gondozó mindennapi segítségére szorulnak, így a demenciára vonatkozó bármely cselekvési tervben hangsúlyos szerepet kell kapnia ennek az ellátási formának, ennek a gondozói csoportnak.

A demenciával élőkkel kapcsolatba kerülők, az életminőségükre hatással lévők köre még tágabb. A megszemélyesíthető szereplőkön és intézményeken kívül társadalmi tényezők is hatással bírnak a jóllétre. A kapcsolatok széleskörüek, akár területi, közösségi szinten is feltérképezésre érdemesek (Fekete, 2017a). A nem meglepő módon fontos szakápolóiés orvosi ellátás mellett a hozzátartozók jelentette háttér, valamint az információval rendelkezés, az elérhető ismeret mennyisége és minősége, ehhez kapcsolódóan a stigmatizáció, a betegséggel/beteggel szembe kerülve jelentkező elutasítás, kirekesztés bizonyult hangsúlyos, az egyéni jóllétet meghatározó körülménynek.

Nemzetközi érdekképviselet és tudásmegosztás

Az Egészségügyi Világszervezet (World Health Organization, WHO) 2008-ban nyilvánította a demenciát ,prioritást érdemlő" állapotnak. Az odafigyelést érdemlő kórképek között jellemzően egyrészt a fejlett világban előforduló nagy mortalitású vagy jelentős költségigényű betegségek, kóros állapotok szerepelnek, másrészt a fejlődő világban nagy tömegeket érintő, szintén gyakran - bár inkább az ellátási hiányosságok miatt - jelentős mortalitású, többnyire fertőző betegségek szerepelnek.

A demencia ezen listára vételét az indokolja, hogy a kognitív zavarhoz vezető kórképek jelentős többségének nincs gyógyulást eredményező terápiája - ma sem, ahogy 2008-ban sem volt -, az időben elkezdett gyógyszeres kezeléstől legfeljebb az állapot rosszabbodásának mérséklése várható. Mindennek igen nagy jelentősége lenne, ha ezáltal a demenciával élő személy önállóságát, minél több részfunkcióban az önellátóképesség megörzését hosszabb ideig lehetne fenntartani. A WHO a tagállamok érdemi cselekvését elősegítendő 2018 júniusában adta ki „,Towards a dementia plan: a WHO guide” címü kiadványát. Ezt megelőzően 2017 májusában a „,The global action plan on the public 
health response to dementia 2017-2025" címen elfogadott akciótervben 7 területet definiáltak, melyeknek a cselekvés fókuszát kell képezniük, úgymint:

- demencia, mint közegészségügyi prioritás

- figyelemfelhívás - demenciatudatosság, demenciabarát megközelítés

- demencia kockázatának csökkentése

- demencia diagnózisa, kezelése, gondozás és támogatás

- gondozók támogatása

- informálás

- kutatás és innováció.

A WHO útmutatója az első cselekvési fókusz, a priorizálás megvalósítását tủzte ki célul. Ehhez a kezdeményezéshez kapcsolódik a „The Global Dementia Observatory”, mely szintén a WHO munkája, és az adat- és tudásmegosztás szándékával hozták létre 2018ban, annak érdekében, hogy segítse a döntéshozókat. Az akcióterv emellett figyelembe veszi a fenntartható fejlődési célkitüzéseket is (Sustainable Development Goals - United Nations General Assembly resolution 70/1.), mely szerint minden emberi lénynek lehetőséget kell biztosítani a méltóságra és egyenlőségre. Ugyancsak összhangban van az ajánlás az Egyesült Nemzetek fogyatékkal élök védelmében elfogadott egyezményével „,United Nations' Convention on the Rights of Persons with Disabilities ”38. Az akcióterv kidolgozása érdekében széleskörü konzultáció történt: WHO tagállamokkal, ENSz szervezetekkel, továbbá civil szervezetekkel, a magánszektor képviselőivel, jótékonysági szervezetekkel, akadémiai intézményekkel, de demenciával élőkkel és az ő gondozóikkal, családtagjaikkal is. A fenntarthatósági törekvésekkel összhangban összegző és multiszektoriális megközelítést alkalmaz, beleértve a szociális és egészségügy ellátórendszer összehangolását, melynek kiemelt célkitüzése a jóllét biztosítása és átfogóan tekint a megelőzés, kezelés, rehabilitáció, gondozás kérdésére. A terv konkrét akciókat határoz meg, valamint javaslatot tesz indikátorokra, célokra. Iránymutatást fogalmaz meg, melyek a demencia-szakpolitika fejlesztéséhez alkalmazhatóak országok

\footnotetext{
${ }^{38}$ https://www.un.org/development/desa/disabilities/convention-on-the-rights-of-persons-withdisabilities.html
} 
szintjén, segítve azok összehangolását az adott egészségi ellátási struktúrával, a nemfertőző-betegségekre vonatkozó, az idősügyi, valamint a fogyatékossági stratégiával.

A „demencia terv" elkészítéséhez három fázisba sorolva fogalmaz meg konkrét, szükségszerünek minősített gyakorlati lépéseket, melyek háttere az elmélet mellett országok konkrét gyakorlatai. Az egyes szakaszok tevékenységei:

- „A-szakasz” - a terv előkészítése:

A tervezés szakaszának két fő lépése van. Az egyik a helyzetelemzés, a másik a prioritások azonosítása. A helyzetelemzés része kell, hogy legyen a demenciával élők, valamint gondozóik, családtagjaik, minden érintett szükségleteinek, igényeinek és egészségi állapotának felmérése, ahogy az ellátási hiányosságok, a rendszerben rejlő lehetőségek, az adott források és eljárásrendek számbavétele. Ezt követően a helyzetelemzés feltáró munkáján alapuló priorizálás következik, annak megállapítása, hogy a témák, célkitüzések milyen fontossági sorrendben kövessék egymást.

- „B-szakasz” - a terv fejlesztése

A fejlesztés szakasza a tervezés során gyüjtött tényekre épül, amelyek alapul szolgálnak a terv hatályának, kiterjedésének definiálásához, hogy a prioritások végeredményben egységes egészet alkossanak. A keret meghatározása azt jelenti, hogy rögzítésre kell, hogy kerüljön, hogy mit kíván, illetve tud a terv elérni és mit nem. Ebben a szakaszban három lépés követi egymást: a terv stratégiai keretének felvázolása, az erőforrásokra gyakorolt hatások meghatározása, valamint az érdekelt felek és a politika jóváhagyása.

- „C-szakasz” - a terv megvalósítása

A megvalósítás szintén az előző lépésen, tehát a cselekvési területek és a hozzá rendelt források meghatározásán alapul. A szakasz három lépése a klasszikus menedzsmentfunkciókat követve: operatív tervezés, költség-allokáció, ellenörzés és értékelés.

A WHO célja az irányelv összeállításával, hogy segítséget nyújtson minden tagállamának a demencia-ügyének hatékony előmozdításához, mind a demencia-tervvel, -stratégiával 
már rendelkező, vagy azzal még nem rendelkező országoknak, azoknak, akik egy különálló, csak a demenciát tárgyaló cselekvési terv kidolgozását fontolgatják, és azoknak is, akik egy meglévő (pl. egészségi, társadalmi) programba kívánják a témához kapcsolódó aktivitást beilleszteni és annak keretében megvalósítani.

A demenciával kapcsolatban igen fontos koordináló és informáló szerepet tölt be a WHOval is kapcsolatban álló, az egész világra kiterjedő tevékenységü, 1984-ben alakult Alzheimer's Disease International ${ }^{39}$ (ADI), az Alzheimer-kór - mint a demencia hátterében leggyakrabban álló kórkép - vagy más demencia ügyet képviselő egyesületek, társaságok nemzetközi szövetsége. Jelenleg ${ }^{40} 94$ tagszervezetük van, köztük Magyarországot a Feledékeny (Alzheimer-kórral és más emlékezetzavarral élö) Emberek Hozzátartozóinak Társasága ${ }^{41}$ képviseli tagságával. A szervezet 2016-ban kiadott, 3 évre megfogalmazott stratégiai tervében a következő, mintaként is szolgáló célkitüzéseket határozta meg: a demencia ügyének támogatása globálisan és a tagországokban, annak érdekében, hogy a demenciát kiemelt egészségi problémaként kezeljék; a demenciával élőket és gondozóikat terhelő stigmatizáció mérséklése a demencia iránti figyelem, tudatosság növelésével; a tagok támogatása abban, hogy jobban tudják segíteni az érintetteket; mind a prevenció, mind a kezelés, mind a gondozás terén a kutatások támogatása.

A szervezet 2009-ben tette közzé első alkalommal a „World Alzheimer Report” címü kiadványát, amely azóta évente megjelenik. Már a 2010-es, „, The Global Economic Impact of Dementia" címet viselö riport (Alzheimer's Disease International, 2010) a demencia globális gazdasági hatásával, illetve az eltérő gazdasági státuszú országokban tapasztalható körülményekkel foglalkozott. A jelentésben a demenciát egy fokozatosan növekvő gazdasági terhet jelentő tünetegyüttesként határozták meg, amely miatt az ellátás és az ahhoz való hozzáférés fejlesztésének, javításának, valamint a terápiára irányuló kutatások támogatásának szükségességét emelték ki.

A riport kitért arra, hogy míg az alacsonyabb jövedelmü országokban a legalapvetőbb probléma a demencia felismerésének a hiánya, addig a magasabb jövedelmü országokban bár jobb a helyzet az állapot felismerése tekintetében, ugyanakkor a megnövekedett

\footnotetext{
${ }^{39}$ http://www.alz.co.uk/

${ }^{40} \mathrm{https} / / / \mathrm{www} . a l z . c o . u k / a s s o c i a t i o n s ~(2019.02 .23$.)

${ }^{41} \mathrm{http}: / / w w w . a l z h e i m e r w e b 1 . h u / ~(2019.02 .23$.
} 
ápolási, ellátási igény kielégítésében már elégtelenség mutatkozik, és egyre több beteg és ápoló hozzátartozó marad segítség, támogatás nélkül.

Az informális ellátás, tehát a gondoskodó családtag vagy ismerős által nyújtott, hivatalosan nem megfizetett ápolási munka jelentőségét a költségek megoszlásának becslésekor is megmutatkozóan kiemeltnek értékelték (Ábra 3.). Míg az informális ellátás költsége a szociális ellátás költségével egyező a becslések szerint, addig ahhoz képest az egészségügyi kiadások aránya eltörpül.

Ábra 3. A költségtényezők megoszlása demencia esetén (Forrás: World Alzheimer Report, 2010.; saját feldolgozás)

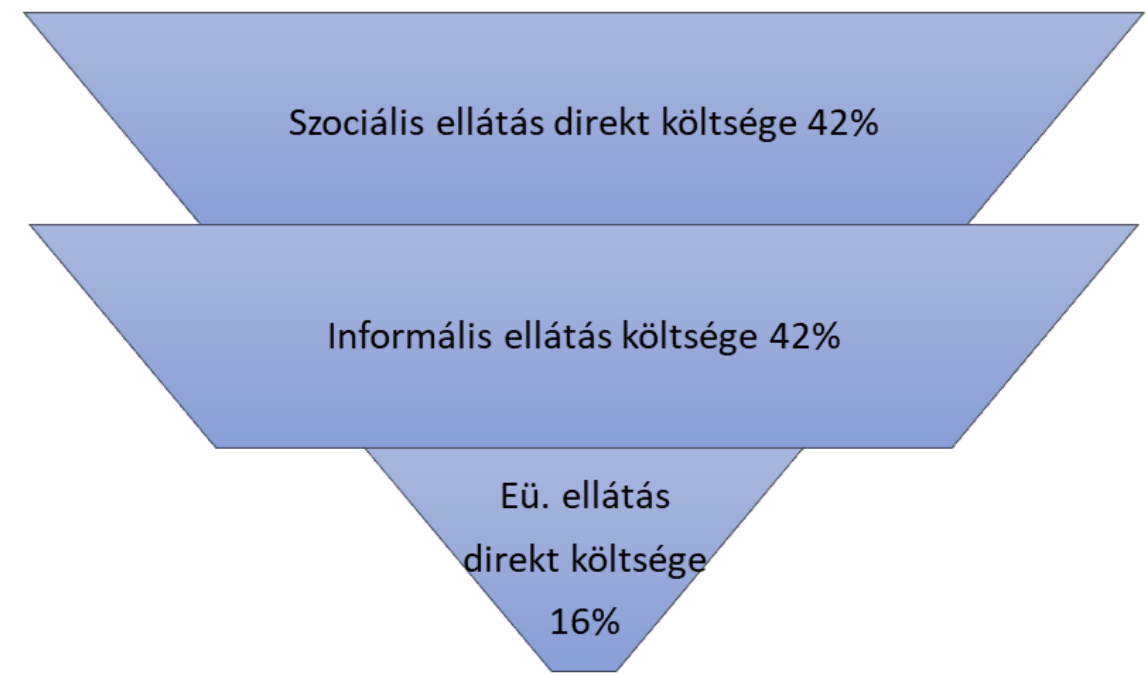

Kitértek arra is elemzésükben, hogy becslésük szerint az alacsony és közepes jövedelmü országokban kiemelkedően magas arányú az informális költségek részesedése, elérheti akár az összköltség 58-65\%-át is, ezzel szemben a szociális ellátásra jutó költségek minimális szintüre csökkennek.

Az Alzheimer's Disease International a költségfókuszú, 2010-es riportjában hét ajánlást is megfogalmaz annak érdekében, hogy ezáltal javítható legyen a demenciával élők növekvő számának költséghatékony ellátása, és hogy az ezirányú kutatások eredményeként az igényeket jobban kielégítő egészségügyi és szociális ellátási csomagok szülessenek. Felhívják a kormányokat, hogy készítsenek nemzeti programot, akciótervet a demencia problémájának kezelésére. Emlékeztetik a döntéshozókat, a mindenkori kormányokat, hogy nemzetközi egyezmények alapján kötelezettségeik vannak a fogyatékkal, akadályozottsággal élök felé (Convention on the Rights of Persons with 
Disabilities $^{42}$ ), valamint az idősek felé (Madrid International Plan of Action on Ageing ${ }^{43}$ ). A WHO mentális egészség biztosítását célzó, az ellátási igények és lehetőségek közötti rés áthidalását szolgáló program (Mental Health Gap Action Programme ${ }^{44}$ ) alkalmazásának keretében a többi közt a demenciával élök ellátásának javítására is lehetőség nyílna. Szintén a WHO kezdeményezése alapján (Innovative Care for Chronic Conditions ${ }^{45}$ ), javasolják az egészségügyi rendszer ellátási fókuszát az akut ellátásról a krónikus betegségek, állapotok kezelése felé áthelyezni tekintettel többek között a társadalom elöregedésére, mivel a betegségstruktúra átrendeződése ezt kívánja. A kezelés mellett a hosszútávú ápolás iránti igény megnövekedésére is fel kell készülni, és ki kell dolgozni ennek terveit is, figyelembe véve az ápolást végző családok helyzetét is. Továbbá javasolják a szociális védelmi rendszer áttekintését, hogy az megfelelően szolgálja-e a demenciával élők és a róluk gondoskodók érdekeit. Ösztönzik emellett a demenciát célzó kutatási támogatások növelését, azon belül is a társadalmi, gazdasági hatások felmérését.

A 2016-os dolgozatban ismét kiemelt figyelmet kapott a költségek kérdése is, mint a demencia egyik globális hatása (The Global Impact of Dementia: An analysis of prevalence, incidence, cost and trends) (Alzheimer's Disease International, 2016). A költségek növekedését három tényezővel magyarázták, úgymint a demenciával élők számának emelkedése - az elérhető élettartam kitolódása miatt -, az ellátás költségeinek növekedése, valamint a diagnózis elérésének növekedése, ami végeredményben szintén az érintettek számának emelkedéséhez fog vezetni. A költségek megfékezésének egy lehetséges módjaként az úgynevezett „feladat-vezérelt ellátást” határozzák meg, melynél nem a szakellátás van a fókuszban, hanem az alapellátás megerösítésére helyezik a hangsúlyt a rendszer optimalizálásánál, hatékonyabbá tételénél. Az ellátás megszervezéséért felelős személy (esetmenedzser) - akár a demenciával élők, akár az idősek, elesettek, akár bármely krónikus állapottal élők - segítéséért is felelős, a kielégítetlen szükségletekre koncentráló ellátás, lehetőleg alapellátási szinten történő megszervezése egyúttal személyközpontúbb, holisztikus, átfogó és integrált lesz, összességében ezzel is jobb ellátási minőséget biztosítva.

\footnotetext{
${ }^{42} \mathrm{http}: / /$ www.un.org/disabilities/convention/conventionfull.shtml

${ }^{43}$ http://undesadspd.org/Ageing/Resources/MadridInternationalPlanofActiononAgeing.aspx

44 http://www.who.int/mental_health/mhgap/en/

45 http://www.who.int/chp/knowledge/publications/icccreport/en/
} 
Egy másik ernyőszervezet, az Alzheimer Europe, amely 37 országból 42 taggal rendelkezik (2018 novemberében frissített adatok alapján ${ }^{46}$ ), valamint további 5 országból tagjelölti státuszban lévő szervezetekkel tartja a kapcsolatot, köztük Magyarországról a Szociális Klaszterrel ${ }^{47}$. A szervezet 2006 óta adja ki „Dementia in Europe Yearbook”"48 címmel az évkönyvét, melynek évről-évre más témát helyeznek a fókuszába. A szervezet honlapján számos európai ország nemzeti demencia stratégiáját teszi közzé, melyek tanulságokkal és mintául szolgálhatnak mindazoknak, akik még ezen munka előtt állnak.

Demencia stratégiák - minták előttünk

A WHO és a nemzetközi demencia ernyőszervezetek mellett az Európia Unió intézményei is ösztönzik a demenciával, mint stratégiai fontosságú kérdéssel történő foglalkozást. Az Európai Bizottság 2009 júliusában közzétett, „az Alzheimer-kórra és más demenciákra irányuló európai kezdeményezésröl" címü közleményben ${ }^{49}$ ösztönzi a tagállamokat, hogy alakítsanak ki demencia stratégiát. Az Alzheimer Europe honlapján teszi közzé tagországai cselekvési terveit (National Dementia Strategies ${ }^{50}$ ). A honlap 2018 novemberben frissített adatai szerint az ernyőszervezet jelenleg 37 ország 42 szervezetével áll kapcsolatban, közülük 32 ország 36 szervezete teljes jogú tag és további 5 ország 1-1 szervezete, valamint Bulgáriának egy második szervezete a tagság előszobájában van. A honlapon keresztül 31 tagország - köztük az Egyesült Királyság 4 tagállama külön-külön, valamint Belgiumban a flamand és vallon régió külön-külön tervei közül az előbbi - demenciához kapcsolódó stratégiájáról vagy az előkészületeiről tudhatunk meg bővebb információkat, bár az adatok frissítése igen változó, van, ahol 6 éve nem frissítették a leírtakat.

Az első európai ország, amely demencia stratégiával rendelkezett, Franciaország volt. 2001-ben 4 évre szóló stratégiát hirdettek meg, melyet egyből követett egy 3 évre szóló, majd 2008-ban már 5 évre elfogadott program. A harmadik terv részletes kiértékelését és

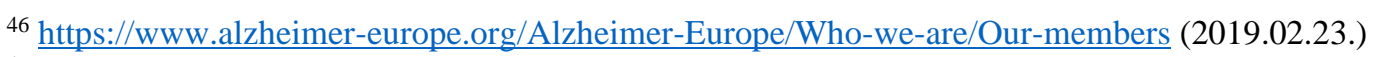

47 http://www.szocialisklaszter.hu/

48 http://www.alzheimer-europe.org/Publications/Dementia-in-Europe-Yearbooks

49 http://eur-lex.europa.eu/legal-content/HU/TXT/HTML/?uri=CELEX:52009DC0380\&from=HU (2019.02.23.)

${ }^{50}$ https://www.alzheimer-europe.org/Policy-in-Practice2/National-Dementia-Strategies (2019.02.23.)
} 
javaslatok megfogalmazását követte 2014-ben a már 4., elődeinél átfogóbb, a neurodegeneratív betegségekre - így az Alzheimer-kór mellett a Parkinson-kór és a Sclerosis multiplex betegségekre - vonatkozó terv kihirdetése. Az ebben megjelölt három kiemelt cél: a diagnosztika és a betegmenedzselés javítása; a betegséggel élők és gondozóik életminőségének javítása; a kutatási tevékenység növelése és koordinálása.

A cselekvési tervek kibővítése a demencián túl más neurodegeneratív, azaz az idegrendszer leépülésével járó kórképekre új tendencia. Ezt a megoldást választotta az első programját 2016-ban meghirdető Spanyolország, és a programját 2015-ben megújító Anglia is a kutatások ösztönzését nem csupán a demenciára, hanem minden más neurodegeneratív kórképre kiterjesztve fogalmazta meg.

Franciaországot Hollandia követte a sorban 2004-ben, így itt is már a harmadik, 2020-ig dedikált program megvalósulása zajlik. Két éves előkészítő munka után 2013-ban hirdették ki ezt a Delta Terv Demencia (Delta Plan Dementia) címet viselő stratégiát. Az elnevezés kifejezi annak felismerését, hogy a probléma mekkora jelentőségü, mivel a „delta terv" nevet korábban az a program viselte, amelyet a Hollandiában 1953-ban bekövetkezett nagy áradáshoz hasonló újabb természeti katasztrófák megelőzése érdekében hoztak létre. A következő „ébredő” Norvégia volt 2007-ben, ahol már ekkor egy hosszabb távú, 7 éves programot indítottak el, és a jelenleg futó második, 2020-ig szóló stratégia fókuszában is feltünik egy új, napjainkban egyre többször említett fogalom, a „demenciabarát” körülmények megteremtése. Norvégia „demenciabarát társadalom” megteremtését tűzte ki célul, ahogy Wales is a legfrissebben, 2018-ban indított, már második tervében. Az első programját 2015-ben meghirdető Málta a gyakorlatban alkalmazta a demenciabarát attitüdöt, mivel nyolcéves programját egy egyszerüsített, demenciabarát verzióban is közzé tette.

Az első stratégiájukat 2009-2011. között indító országok - Belgium, Dánia, Skócia, Wales - ma már legalább a második programjuk megvalósításán dolgoznak. Finnország, egyedi módon már az első, 2012-ben induló tervét hosszabb, 8 éves tartamúra szabta. Azok az országok, amelyek 2013-ban vagy az azt követő években jutottak el az akciótervük kihirdetéséhez - Ausztria, Csehország, Görögország, Luxemburg, Olaszország, Írország, Izrael, Szlovénia, Svájc vagy Svédország - már sokat tanulhattak az úton előttük járóktól, amelyek a programokban visszaköszönő célkitüzésekben is megmutatkozik. 
Összesen 22 ország demenciastratégiájába nyerhetünk betekintést az Alzheimer Europe gyüjtésének köszönhetően, és további 9 országban zajló előkészületekről olvashatunk információkat. Eszerint Bosznia-Hercegovina, Bulgária, Ciprus, Gibraltár, Lengyelország, Portugália, Románia, Törökország, Németország nem rendelkezik demencia stratégiával, bár utóbbi 2 szövetségi állama (Bajoroszág és a Saar-vidék) 2013ban területi hatályú programot hirdetett, de valamiféle elökészület már dokumentálható volt. Több országban ezek az elökészületek már 5 vagy akár 8 éve zajlanak. A további tag- vagy tagjelölt államokban zajló munkáról nem elérhető információ ezen a forráson keresztül.

Kanada 2017 nyarán hirdette ki, hogy - számításuk szerint harmincadik országként hamarosan nemzeti demencia stratégiát fog alkotni. Ennek apropóján született egy összegző publikáció, mely a megelőző 29 cselekvési terv összehasonlítását és áttekintését tüzte ki célul, annak érdekében, hogy a demencia ügyéhez kapcsolódó minden szerepvállalót informáljon (Chow, 2018). A szerzők információforrásul az Alzheimer Disease International ernyőszervezet honlapját és azon belül a demencia stratégiákra vonatkozó információkat ${ }^{51}$ használták. Megjegyzendő, hogy más források felhasználásával már ekkor több ország demencia stratégiájához jutottak volna hozzá, ugyanakkor valóban példaértékü az összegző munka, amely a nyelvi akadályokat leküzdve - akár online fordító alkalmazásával, akár más nem hivatalos fordítás vagy az angol nyelvü összefoglalások tartalma alapján - igyekezett szisztematikusan információhoz jutni, és ezeket részletesen feltárni, közölni is. Így nem csupán az akcióterv bevezetésének időpontját, hanem azok fő célkitüzéseit és tevékenységeit is ismertetik, valamint információkat közölnek a bevont szereplőkről, közreműködőkről, a terv megvalósításának módjáról, és bár kevés esetben, de a megvalósításhoz rendelt pénzügyi forrásokról is, ha ilyen adatok elérhetőek voltak.

Az Európán kívüli országok szintén többnyire 2010 után eszméltek és alkották meg stratégiájukat. Dél-Korea volt az egyik első 2010-ben, akit az Egyesült Államok követett 2012-ben egy kifejezetten hosszútávú, 2025-ig szóló programmal. 2013 és 2016 között alkotta meg programját Mexikó, Ausztrália, Kuba, Indonézia, Japán, Puerto Rico és Tajvan. A kanadai összegzés információforrásául szolgáló honlapon azóta Chile és Katar is a stratégiával rendelkező országok között szerepel. Kanada egyébként még nem

\footnotetext{
${ }^{51}$ https://www.alz.co.uk/dementia-plans $(2019.03 .01)$
} 
rendelkezik kormányzati stratégiával - annak elkészültét a kanadai társaság 2019 telére valószínüsíti. Nem kormányzati programmal rendelkezik továbbá az elöregedő társadalmú Új-Zéland és az ugyan fiatal, de abszolút számban sok időssel rendelkező India is

Az összegző publikáció (Chow, 2018) öt prioritást azonosított, melyek a stratégiák többségében szerepelt, ezek: a demenciával kapcsolatos tudatosság növelése, a támogató szolgáltatások fejlesztése, az ellátás minőségének javítása, a szakmai képzés javítása, valamint a kutatás előmozdítása. Szintén kiemelt jelentőségünek és visszatérő célnak bizonyult a betegséghez kapcsolódó stigmatizáció / megbélyegzés csökkentése.

A szerzők arra vonatkozóan is keresték az információt, hogy milyen forrást rendeltek a program megvalósításához, illetve, hogy a megvalósítás hogyan történik. Mindkét tényezőnek nagy a szerepe abban, hogy a tervek meg tudnak, meg fognak-e valósulni. Szintén egy garanciális elemként értékelték, ha a stratégia mérföldköveket, célokhoz rendelt határidőket is tartalmaz, valamint, ha abban elöre rögzítik, hogy a megvalósulást, az eredményeket milyen módon mérik, értékelik. Tanulságos, hogy a 25 részletesen áttanulmányozott cselekvési tervből csupán az esetek felében (13 országban) jelöltek meg pénzügyi forrást, és mindössze hatban rendeltek konkrét összeget a megvalósításhoz. A „hogyanra”, a megvalósítás módjára is mindössze 16 ország programja tért ki.

A szerzők arra is kitérnek, hogy nem tisztázott, hogy Kanadának eddig miért nem született a demenciával élőkre vonatkozó stratégiája. (Kanadában a 2016-os cenzus alapján a 65 év feletti lakosság aránya 16,9\% volt ${ }^{52}$ ). A hasonló ügyek kapcsán gyakran felmerülö ellenérdekeltség, politikai megfontolások és a kötött finanszírozási források miatt a más ügyekkel való versengés kényszere mellett felvetik az „ageism” - a kor szerinti diszkrimináció - és a demencia kapcsán gyakran említett stigmatizáció, valamint ennek eredményeként, akár intézményesült formában kialakuló kirekesztés lehetséges szerepét is.

A saját gyüjtés és a kanadai stratégiahirdetést megelőzően végzett tudásösszegzés egymással összecsengően igazolja, hogy a demencia, mint társadalmi ügy érdekében végzett stratégiaalkotásnak mára kiforrott menete van. A kormányzati - központi, régiós, területi - szereplők mellett a szakmai szervezetek széles alapon nyugvó

\footnotetext{
52 https://www12.statcan.gc.ca/census-recensement/2016/rt-td/as-eng.cfm (2019.03.01)
} 
együttmüködésére is szükség van, kiemelten az egészségügyi és szociális ellátók egyenrangúságára alapozva. A civil szférából érkező résztvevők egyrészt tolmácsai az érintett betegek, családok mindennapi problémáinak, illetve nélkülözhetetlen szereplők a támogató tevékenységek megvalósításában, melyet a stratégiák gyakran priorizált célként tartanak számon.

\section{Összefoglalás}

Magyarország tagadhatatlan lemaradásban van a demencia társadalmi szintü problémaként történő kezelésében, abban a tekintetben is, hogy jelenleg nem rendelkezik kormányzati stratégiával erre vonatkozóan. A világszervezetek figyelemfelhívása egyértelmü és nem friss. Minden, de föleg az olyan, Magyarországhoz hasonlóan a társadalom elöregedésének problémájával súlyosabban érintett országnak cselekvési tervvel kell rendelkeznie ahhoz, hogy az idősödő társadalomnak megfelelő életminőséget, méltóságban eltölthető hosszú élettartamot tudjon biztosítani. A demencia és más funkciócsökkenéshez, következményesen önellátási zavarhoz, majd képtelenséghez vezető állapotok hosszú ideig, akár egy - másfél évtizedig kísérői lehetnek az időskornak. A kieső funkciók, képességek többnyire személyes gondozói közremüködéssel pótolhatók, technikai eszközök csak bizonyos résztevékenységek támogatására - pl. fürdetés, mozgatás - állnak rendelkezésre, de a mindennapi cselekvések során az emberi tényező, az „emberi hang”, az érzelmek megfejtése, feldolgozása, tükrözése, a mindennapok értelmének igazolása emberi hozzájárulás nélkül nem lehetséges. Az ápolói tevékenység - akár szakértő, akár laikus végzi - kitartást igényel; kutatások igazolják a negatív hatásokat és azok következményeit. A formális és informális ápolói tevékenységnek is vannak azonban pozitív aspektusai, de utóbbiak esetében ezek külön hangsúlyozást, felismerésük, megélésük támogatást igényel, hiszen az informális ápolók, a gondozó családtagok nem hivatásként választották a segítő munkát, hanem gyakran a helyzet, a kényszer hozza az új szerepet. Nem véletlenül kiemelt téma több akciótervben a családtagok, gondozó hozzátartozók, informális ápolók helyzete, életminősége. A gondozó családtag jólléte a gondozott életminőségét is meghatározza, így az ellátórendszer hatása kettős. Tekintettel arra, hogy a gondozó hozzátartozóknak a szerepük megélése szempontjából különböző csoportjai azonosíthatóak, akik eltérő típusú támogatásra szorulnak, az ismert stressztényezők elhárítása érdekében különböző 
intervenciót kell alkalmazni a különböző csoportok esetén (Fekete, 2017b). Ez azt is jelenti, hogy nem csupán a demenciával élők, hanem a róluk gondoskodók körében is „diagnózist” fel kell állítani, az állapotfelmérést el kell végezni, és ezek eredménye alapján kell személyre-, családra szabott támogatási formát biztosítani.

A demencia társadalmi jelentőségének felismerése, és az érintettek méltóságteli életének biztosítását célul kitüző cselekvési terv megalkotása tehát kiemelten fontos a demenciával élőket gondozó hozzátartozók szempontjából. Az ő magára hagyásuk vagy megfelelő támogatásuk, segítésük a gondozói szerepben, annak összehangolása más szerepeikkel legalább akkora hatással bír az ország gazdasági-társadalmi helyzetére, mint a demenciával élők számából adódó hatás.

A már létező stratégiák számos ponton támpontot nyújthatnak a folyamatban hátrébb járó országoknak. A nemzetközi tudásmegosztás a programok megalkotásán túl a megvalósulás követésében, az eredmények értékelésében, új mérföldkövek meghatározásában is segít. A kutatási eredmények megosztása jó példa lehet a szakpolitikát müvelöknek, és ösztönzőleg hathat a jó gyakorlatok országokon átívelö terjesztésére. A tudomány- és szakterületek közti együttműködést ugyanakkor egy adott országban, akár azon belüli régiókban is meg kell valósítani, hiszen így biztosítható az ott élöket, érintetteket valóban szolgáló tevékenységek definiálása, majd elindítása. A társadalmi fenntarthatóság szempontjából kulcsmozzanatként rajzolódik ki a demenciával élők családjainak komplex támogatása, amelynek kidolgozása még az előtt elengedhetetlen, hogy a neurokognitív zavarok felismerésének javulása - mint szintén gyakori stratégiai prioritás - eredményeként az egészségügyi és szociális ellátórendszerben az eddigi igény többszöröse jelentkezik.

Irodalomjegyzék

Alzheimer's Disease International. 2010: World Alzheimer Report 2010: The Global Economic Impact of Dementia. https://www.alz.co.uk/research/files/WorldAlzheimerReport2010.pdf (2019.09.22)

Alzheimer's Disease International. 2016: World Alzheimer Report 2016: The Global Impact of Dementia: An analysis of prevalence, incidence, cost and trends. http://www.alz.co.uk/research/world-report-2015 (2019.02.22) 
Alzheimer Europe. 2013. Dementia in Europe Yearbook 2013. https://www.alzheimereurope.org/Media/Files/9.-Publications/AE-Yearbooks/2013-Alzheimer-Europe-Yearbook (2019.02.28)

Alzheimer Europe. 2018. Dementia in Europe Yearbook 2018. https://www.alzheimereurope.org/Media/Files/9.-Publications/AE-Yearbooks/2018-Alzheimer-Europe-Yearbook (2019.02.28)

American Psychiatric Association, 2013. Highlights of Changes from DSM-IV-TR to DSM-5 https://www.psychiatry.org/psychiatrists/practice/dsm/educational-resources/dsm-5-fact-sheets (2019.03.26)

Campbell, J.C., Ikegami, N. 2000: Long-Term Care Insurance Comes To Japan. Health Affairs (19), 3, 2639.

Campbell, J.C., Ikegami, N., Gibson M.J. 2010: Lessons From Public Long-Term Care Insurance In Germany And Japan. Health Affairs (29), 1: Advancing Long-Term Services \& Supports

Chow, S., Chow, R., Wan, A., Lam, H., Taylor, K., Bonin, K., Rowbottom, L., Lam, H., DeAngelis, C., Herrmann, N. 2018: National Dementia Strategies: What Should Canada Learn? Canadian Geriatrics Journal (21), 2, 173-209.

De Meijer, C., Wouterse, B., Polder, J., Koopmanschap, M. 2013: The effect of population aging on health expenditure growth: a critical review; European Journal of Ageing (10), 4, 353-361.

European Commission. 2018: The 2018 Ageing Report: Economic and Budgetary Projections for the EU Member States (2016-2070) Institutional Paper 079. May 2018. Brussels. ISBN 978-92-79-77460-7 https://ec.europa.eu/info/sites/info/files/economy-finance/ip079_en.pdf

Fekete, M. 2017: Rendszertérképezés alkalmazása a hazai demenciastratégia megalapozásához. Vezetéstudomány (48), 12, 24-32.

Fekete, M., Szabo, A., Stephens, C., Alpass, F. 2017: Older New Zealanders in caregiving roles: Psychological functioning of caregivers of people living with dementia. Dementia (0), 0, 1-16. DOI: $10.1177 / 1471301217725897$

Goldmann, R., Gyetvai, G., Mester, D. 2016: A szociális ellátórendszer jellegzetességei, korprofilja és területi megoszlása. Társadalmi riport (14), 1, 358-377.

Gulácsi, L. 2012. Egészség-gazdaságtan és technológiaelemzés. Medicina Könyvkiadó Zrt., Budapest.

Gustafson, L. 1996: What is dementia? Acta Neurol. Scand., Suppl. 168, 22-24.

Jönsson, L., Wimo, A. 2009: The Cost of Dementia in Europe - A Review of the Evidence, and Methodological Considerations. PharmacoEconomics (27), 5, 391-403.

Kerekes, S. 2009. A környezetgazdaságtan alapjai: Fenntartható fejlődés, természeti erőforrásgazdálkodás, gazdasági eszközök. Aula Kiadó, Budapest, 2009. ISSN 1788-4713 
Kovács, T. 2016: Demencia a mindennapi gyakorlatban - Összefoglaló közlemény. Korszerü Kaleidoszkóp (2), 2, 3-8.

Krol, M., Papenburg J., van Exel J. 2015: Does including informal care in economic evaluations matter? A systematic review of inclusion and impact of informal care in cost-effectiveness studies. Pharmacoeconomics (33), 2, 123-35.

OECD. 2011: Compendium of OECD Well-Being Indicators. www.oecd.org/sdd/47917288.pdf (2019.02.22)

OECD, 2019: Elderly population (indicator). doi: 10.1787/8d805ea1-en

Pearlin L.I., Mullan J.T., Semple S.J., Skaff M.M. 1990: Caregiving and the Stress Process: An Overview of Concepts and Their Measures. The Gerontologist (30), 5, 583-594.

Prince, M., Bryce, R., Albanese, E., Wimo, A., Ribeiro, W., Ferri C.P. 2013: The global prevalence of dementia: a systematic review and metaanalysis. Alzheimers Dementia (9), 1, 63-75.

Rechel, B., Grundy, E., Robine, JM., Cylus, J., Mackenbach, J.P., Knai, C. and others. 2013: Ageing in the European Union. The Lancet (381), 9874, 1312-1322.

Wübker, A., Zwakhalen, S., Challis, D., Suhonen, R., Karlsson, S., Zabalegui, A., Soto, M., Saks, K., Sauerland, D. 2015: Costs of care for people with dementia just before and after nursing home placement: primary data from eight European countries. The European Journal of Health Economics (16), 7, 689-707.

WHO, 2008: Mental Health GAP .....

WHO. 2017: Global action plan on the public health response to dementia 2017 - 2025. ISBN 978-92-4$151348-7$

WHO. 2018: Towards a dementia plan: a WHO guide. ISBN 978-92-4-151413-2

WHO. 2018: The Global Dementia Observatory Reference Guide. Geneva, Switzerland. Licence: CC BYNC-SA 3.0 IGO. https://www.who.int/mental_health/neurology/dementia/gdo_reference_guide/en/ (2019.03.31) 


\section{4. Összegzés}

A Világbank ENSZ adatokon alapuló elemzése (World Bank Group, 2016) szerint a globális demográfiai helyzet a jelenlegi évtizedben meghatározó fordulóponthoz érkezett. Egyúttal alapvetően két csoportra váltak szét a világ országai. A világ lakosságának körülbelül fele olyan országban él, ahol a népességgyarapodás üteme lelassult vagy akár negatív előjelüvé vált, és a populációban növekedni kezdett az időskorúak aránya. Ezeknek a területeknek a tipikus példái az észak-amerikai és európai országok, köztük Magyarország. A Föld népességének másik fele ugyanakkor magas fertilitású, „fiatal” országokban él, és az itt tapasztalható népességgyarapodás felelős tulajdonképpen a még mindig folytatódó globális népességnövekedésért. Az afrikai országok jelentik a tipikus példát, ugyanakkor a népesség növekedése a két óriásállamra, Indiára és Kínára is igaz, ahol azonban a társadalom elöregedésének numerikus dimenziója miatt szembesülnek kihívással.

A társadalom elöregedésének mind numerikus, tehát abszolút értékben vett, mind strukturális, arányokban megjelenő formája az informális ápolás jelentőségének növekedéséhez vezet. Egyrészt a jólléti ellátások kapacitáshiánya, másrészt a családon belüli gondoskodás centralizálódása, egy vagy néhány családtag szerepvállalása, mindemellett a társadalmi szerepek változása miatt az informális ápolást végzők minden eddiginél nagyobb tehernek vannak kitéve, minden eddiginél több és szervezettebb támogatásra van szükségük.

Az informális ápolást végzők egy speciális csoportja a demenciával élőket gondozók. A demencia egy olyan tünetegyüttes, amely az érintett betegeket számos mindennapi tevékenység ellátására fokozatosan képtelenné teszi, a funkcionális korlátozottság végül teljes önellátási képtelenséghez vezet. Az elöregedő társadalmakban a demenciával élök száma növekedni fog, így megkerülhetetlen társadalmi kérdéssé válik a róluk való gondoskodás. Tekintettel arra, hogy a demenciával járó kórképek terápiás lehetőségei erősen korlátozottak, tünetek kialakulása után terápia ellenére sem várható azok eltünése, így az érintett betegek családjának, környezetének akár évtizedes tartamú feladatra kell felkészülnie. A jóléti állam által elvi szinten biztosítható intézményi és szolgáltatási háttér kevés országban áll rendelkezésre korlátlanul, így a család gondozói szerepvállalásának mértéke gyakran nem választás, tudatos döntés kérdése, hanem kényszer, mely hatással 
van a társadalom életminőségére. Több kutatás célozta meg már eddig az öregedő populációjú európai országok intézményi gondozási rendszereinek, az úgynevezett tartós ápolási szolgáltatást (long-term care) nyújtó rendszereknek az áttekintését. Egy publikálás előtt álló, társszerzőkkel együtt végzett saját kutatás is igazolja az európai rendszerek meghatározott típusainak elkülönülését. A 2. Mellékletben ismertetett kutatásban az életminőség és a tartós ápolási szolgáltatás közötti összefüggést vizsgáltuk. Kutatásunk eredményeként a korábbi rendszerfelosztásoktól valamelyest eltérö, de azoknak nem ellentmondó tipizálást állítottunk fel. Eszerint a rendszerek minimalizáló. optimalizáló vagy maximalizáló módon müködnek, aszerint, hogy milyen mértékü invesztíció történik az adott rendszerekbe. Magyarország és a többi, a korábbi besorolások szerint a „családon alapuló” (family-based) vagy „közép-kelet-európai” (Central-Eastern European) rendszerekkel jellemzett országok az időskorúak életminőségének felmérése alapján a „minimalizáló” csoportba kerültek.

Elégséges formális gondozási kapacitás esetén is szükséges azonban a beteget „kísérő” családtagok, barátok támogatása a gyakran nehéz, fájdalmas lélektani állapotban. Ez a támogatás megvalósulhat információ nyújtása, a gondozott számára nappali ellátás biztosítása vagy önsegítő kör szervezése formájában (Lamura et al., 2008).

A „Rendszertérképezés alkalmazása a hazai demenciastratégia megalapozásához” címmel publikált (Fekete, 2017) kutatásom célja az volt, hogy széles szakértői bázison alapuló tudásmegosztás révén feltárjuk, hogy Magyarországon mely tényezők befolyásolják a demenciával élők életminőségét. A komplex oksági diagramon négy fő terület rajzolódott ki (6. ábra):

6. ábra: Demenciával élők életminőségét befolyásoló tényezők (Forrás: Fekete, 2017, 4. ábra)

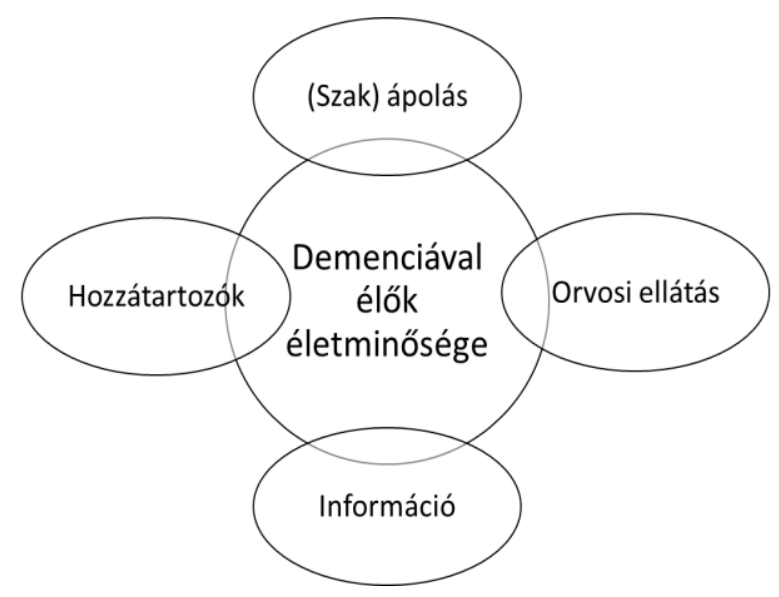


A szakápolás és orvosi ellátás mellett az információ és a hozzátartozók kerültek kulcstényezőként azonosításra. A demenciastratégiával már rendelkező országok cselekvési terveiben megjelölt fő célkitüzésekkel összevetve az eredményt a részvételi rendszerdinamikai modellezés alkalmas módszernek ígérkezett egy szakpolitikai beavatkozást igénylő probléma megoldásának elökészítéséhez, ahogy azt a módszerrel kapcsolatban korábban leírták (Leischow és Milstein, 2006).

A demenciával élőket gondozó hozzátartozók szerepének azonosítása után fordult érdeklődésem az informális ápolásnak a demencia kapcsán felmerülő jelentősége felé. Az informális ápolás szerepének szélesebb kontextusban történő megismerése során mindvégig követtem a demenciára vonatkozó specialitásokat. Krol és munkatársai (2015) az informális ápolás gazdasági tényező volta mellett érvelve olyan kórképeket kísérő ápolási feladatok számbavételét követték nyomon, mint az Alzheimer-kór, a Parkinsonkór, a rheumatoid arthritis (ízületi gyulladás) és az áttétet adó vastagbéldaganat. A szisztematikus irodalomkutatás során feltárt publikációk közül relevánsnak ítéltek közel kétharmada Alzheimer-kórhoz kapcsolódott. Az Alzheimer Disease International (ADI) nemzetközi ernyőszervezetnek köszönhetően rendelkezésre állnak a családok anyagi terheire vonatkozó adatok (ADI, 2015).

A demenciával élőket gondozóknak azonban nem csak anyagi terhekkel kell szembenézniük. Pearlin és munkatársai (1990) az Alzheimer-kórban szenvedők informális ápolóira ható tényezőket egy stressz-modellben összegezték (7. ábra).

7. ábra: Pearlin Alzheimer-betegek ápolóira vonatkozó stressz-modellje (Forrás: Pearlin et al., 1990, saját feldolgozás)

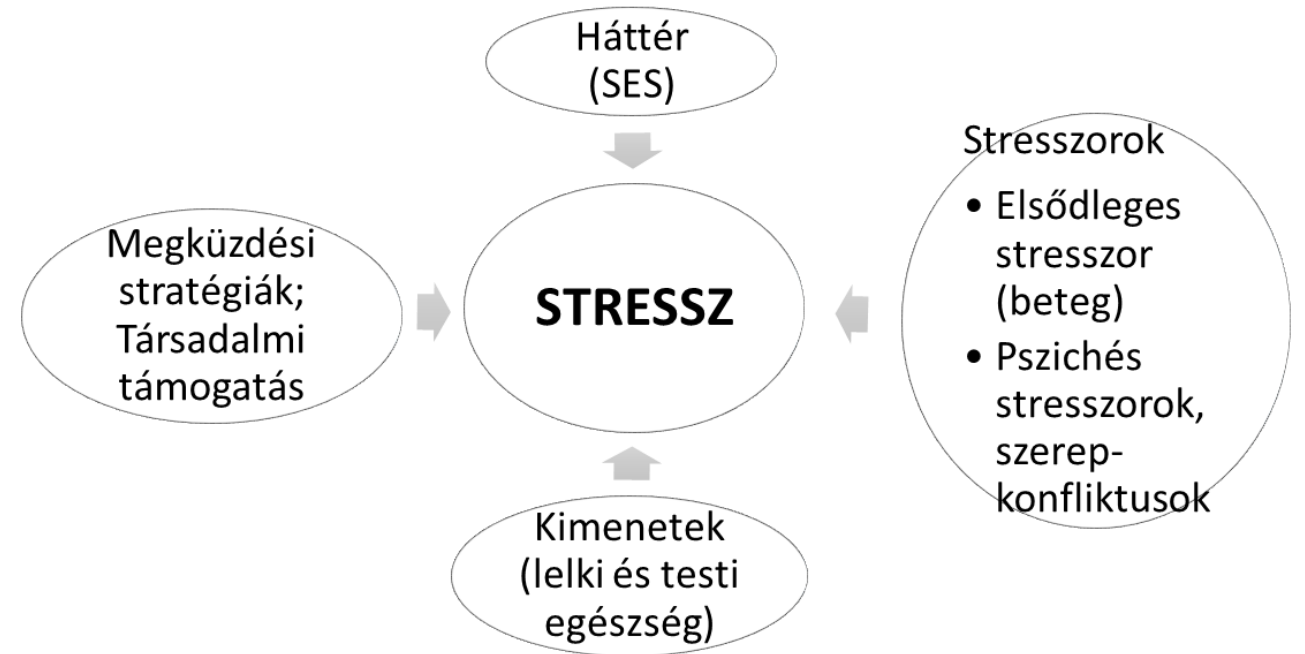


A modell szerint a gondozói terhelés kialakulását négy tényezővel lehet magyarázni. Elsődleges stresszorként jelenik meg a beteg és az ő aktuális állapota. Másodlagos stresszorként a pszichés hatásokat, valamint a gondozói szerepből eredő konfliktusokat azonosította (ennek része a munkavállalás nehézsége, az anyagi problémák jelentkezése). A stresszorokkal való megküzdés képessége és a társadalmi támogatás léte vagy hiánya is szerepet játszik a teher megélésében, ahogy mindezek következményeinek, a testi és lelki egészség alakulásának a visszahatása.

A demenciával élöket gondozók körében végzett saját kutatásom indítéka a jól-létüket, pszichés állapotukat meghatározó tényezők adott mintán történő feltárása volt. Ahogy korábbi kutatások már rámutattak, a jól-létet meghatározó tényezők egy része befolyásolható, míg egyes adottságok nem vagy nehezebben befolyásolhatóak (Alves et al., 2016; Gitlin et al., 2003; Pinquart és Sorensen, 2004; Wennberg et al., 2015).

A látens profilelemzés módszerével a gondozók három típusát azonosítottuk. Az informális ápolást kizárólagosan terhet képviselő tevékenységként ábrázoló megközelítésnek azonnal ellentmond a gondozók csoportokhoz tartozási megoszlása. A gondozók 60\%-a ugyanis az optimális pszichológiai funkciójú csoportba került, közel 29\%-uk a szuboptimális és 11\% mutatott rossz/gyenge pszichológiai müködést. A profilhoz sorolást négy tényező határozta meg: életminőség, mentális egészség, depresszió, élettel való elégedettség. Az eredményeink alapján a jobb pszichológiai müködést szignifikánsan elősegítő tényező volt a nagyobb gondozói tapasztalat hosszabb ápolási idő -, az élénkebb társasági élet, valamint a jobb anyagi körülmények megléte. Ezek az eredmények rávilágítanak azokra a tényezőkre, amelyeket célozva érdemes intervenciót, támogató tevékenységet végezni, amely egyenesen vezet a gondozói tevékenységet folytatók jól-létének javulásához.

A demenciával élőket gondozó hozzátartozók, informális ápolók jól-létére vonatkozó kutatásokkal a célom az volt, hogy a döntéshozók, a szakpolitika számára a háttér feltárásán túl javaslatokat tegyek a lehetséges beavatkozási pontokra (8. ábra.). 
8. ábra: A publikációk tanulságai mint a szakpolitikai javaslatok forrásai

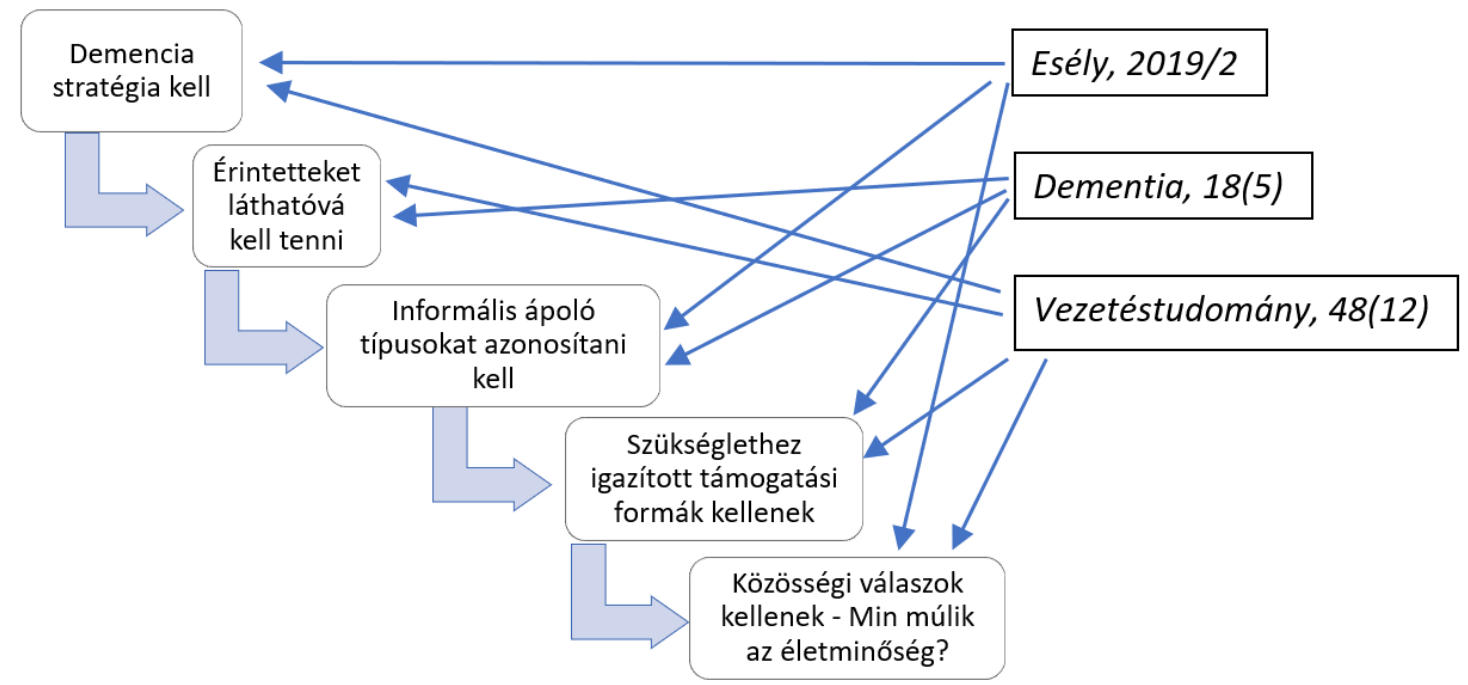

A javaslataimat a saját kutatásaim eredményein túl a más országokban már megszületett, több éven át eredményeket felmutató módon alkalmazott stratégiai tervekre, valamint a társadalmi fenntarthatóság elveire alapozom.

1. Fel kell mérni az enyhe vagy súlyosabb kognitív zavarral, demenciával élők számát, és információt kell nyerni a támogatási szükségleteikről. A támogatási szükségletet nem csupán egyéni, hanem családi szinten kell felmérni, hiszen az informális ápolókra háruló aránytalan teher gyakran éppen abból fakad, hogy az ellátórendszer számára láthatatlanok. Az egészségügyi és szociális ellátók legtöbbször mindössze az érintett beteg szintjéig mérik fel a szükségletet, hiszen munkavégzésük központjában ő áll, és elszámolásuk alapját is a gondozott szükségletei képezik. Fontos lenne tudni, hogy hány gondoskodásra szoruló él egyedül, mivel számukra biztosan intézményi elhelyezés lesz szükséges az állapotuk előrehaladásával, és a férőhelyigény ez alapján tervezhető lenne. Ismerni kéne a gondozó családot, annak minden generációját, felmérni, hogy ki milyen szerepet tud vagy kényszerül vállalni. Más típusú támogatást igényel egy aktív korú hozzátartozó, akinek a jövedelemszerző képességét fenyegeti veszély, és egészen más típusú segítséget igényel egy nyugdíjaskorú gondozó hozzátartozó.

2. A megismert hazai szükséglet típusoknak megfelelö támogatási formákat kell kidolgozni. Az aktív korú informális ápolók számára a munkajövedelem biztosítása az elsődleges cél. Ideális esetben választási lehetőséget biztosítva azon 
a spektrumon, hogy teljes állásban tovább dolgozik vagy a főmunkaidejü munkavégzése a gondozásra szoruló családtag ellátása. Tekintettel arra, hogy a gondozási igény a kognitív zavarral élők esetén fokozatosan nő, így a kívánatos megoldás az lenne, hogy ha a spektrum két végpontja között fokozatosan és igény szerint tudna lépni a gondozó. Például kezdetben napi 1-2 óra munkaidőcsökkentés, akár munkaidőkedvezmény, akár részfoglalkoztatás kiegészítve időarányos ápolási támogatással. A ma müködő hazai támogatási rendszer sem a fokozatokat, sem a logikát nem követi, ráadásul a munkáltatók sem motiváltak a részfoglalkoztatás - legalább ezen okú - biztosításában.

3. A kidolgozott támogatási formákhoz való hozzáférés biztositása a társadalmi fenntarthatóság legkritikusabb pontja. Amennyiben a társadalmi fenntarthatóságot az igazságosság megteremtésével, a társadalmi egyenlötlenségek mérséklésével azonosítom, akkor ma fényévnyi távolságban vagyunk a remélt végcéltól. A támogatásokhoz való hozzáférés ma nem kevés esetben esetleges. Ismét utalva a képességszemléletre, egy gondozó deprimált állapota ma az információ megszerzésének képtelenségével kezdődik, melyet ezt követően az eljárási és érdekérvényesítési képtelenség fokoz, de ezeken is sikeresen túljutva a gondozói lét minőségét, a jól-lét mértékét az egyéni adottságok, az egyéni - gazdasági, kapcsolati - védőháló fogja meghatározni.

4. A társadalomnál kisebb közösségek - akár települések, meghatározott elv alapján szerveződött támogató közösségek, vagy bármely elv szerint definiált, az érintettek mindennapi életében szerepet játszó közösség - szintjén kell felmérni, hogy a demenciával élők és gondozó családtagjaik életminőségét milyen tényezők határozzák meg. A részvétel biztosítása a probléma feltárásában és a megoldási lehetőségek keresésében már önmagában az életminőséget javító tényező (ld. 3. ábra az OECD jól-léti indikátorairól). A folyamatba való bevonás ugyanakkor azt is biztosítja, hogy a témával kapcsolatos információhoz hozzájut az érintett, ezáltal pedig a támogató szolgáltatásokhoz való hozzáférése is javul.

5. A demencia nagy kihívás elé állítja a társadalom egészét, nem csak a közvetlenül érintett családokat. A társadalom elöregedésével olyan mértékben érintett országnak, mint Magyarország, mielőbb átfogó cselekvési tervvel, stratégiával kell rendelkeznie annak érdekében, hogy a jól-léti ellátórendszerek ma is kapacitáshiányos müködése mellett ne következzen be drámai életminőség 
romlás. Az informális ápolók szerepe vitathatatlanul nőni fog az elkövetkező évtizedekben, nem csak a demenciával élők számának növekedése miatt. A társadalom elöregedése más, testi hanyatlással, az önellátásban szerepet játszó funkciók romlásával járó állapotok gyakoribbá válását hozza. A társadalmi egyenlötlenség szempontjából kritikus, hogy az önkéntes, családon belüli gondozói tevékenység valóban „önkéntes”, választott szerep vagy a kényszer diktálta és valójában a társadalmi különbségek további növekedéséhez vezet.

Eddigi kutatómunkám és a jövőben is folytatandó tevékenységem célja, hogy a demenciával élők informális ápolóinak jól-létét biztosító szociálpolitikai döntésekhez releváns információs hátteret, illetve jó gyakorlatokat prezentáljak. Ez a vállalás jelenleg nem tünik sem feleslegesnek, sem gyorsan teljesíthetönek, mivel hazai viszonylatban hatalmas információhiányban szenvedünk. A cselekvés azonban már most is késői, ezért is kell a kutató és beavatkozó munkának párhuzamosan haladnia, és az eredményeket, tapasztalatokat folyamatosan megosztva fejleszteni mindkét tevékenységet. 


\section{Melléklet I. - Civil tudomány és demencia}

A civil tudomány (citizen science) hazai definícióját - a nemzetközi elözményeket ismertetve - leíró Szabó Katalin (Szabó, 2013) mind a civilség, mind a tudományosság meghatározására kitér publikációjában. Eszerint a civil résztvevő lehet abszolút vagy relatív laikus: abszolút/teljesen laikus az, akinek egyáltalán nincs is felsőfokú végzettsége, vagy ha van is, az nem releváns a kutatás szempontjából. Relatív laikusokként azokat definiálják, akik a kutatási területen szakmai tapasztalattal rendelkeznek, de tudományos előmenetelük nincs, nem részesültek soha tudományos képzésben. A kutatás pedig többnyire olyan, melynek sok „kutatóra”, sok résztvevőre van szüksége, mivel nagy mennyiségü adat gyüjtésére, feldolgozására, elemzésére törekszik. Demencia vonatkozásában erre példa az EyesOnALZ ${ }^{53}$ projekt, ami 2016 legelején indult olyan kutatómühelyek együttmüködése révén, melyeknek többek között a Princeton, a Cornell vagy a Berkeley egyetem ad otthont, garantálva a tudományos hátteret. Még ugyanabban az évben elindították az úgynevezett Stall Catchers ${ }^{54}$ nevet viselő játékot, amely valójában a civil tudománynak egy eszköze. A projekt célja, hogy a laikus tömegben rejlő adatfeldolgozó kapacitást használja ki a demencia kezelési módjának megtalálása érdekében. Az adatelemzés tehát egy ,játéknak álcázva” történik, melynek során egerek agyi ereinek véráramlásáról készült rövid videókat néznek a „versenyzők” - a civil tudósok -, és a feladatuk, hogy eldöntsék, hogy egy adott szakaszon a vér áramlik, vagy az áramlás blokkolódik. Jelen játék esetén a civil tudomány alapja ${ }^{55} \mathrm{az}$ a tény, hogy az Alzheimer-kór és más típusú demenciák kialakulása ismerten összefüggésben áll az agyi erek véráramlásával. Nem pontosan ismert azonban az a mechanizmus, ahogy a csökkent véráramlás demenciához vezet. A kutatóknak már több adatbázis, hatalmas adattartalommal áll a rendelkezésére, de azok kielemzése gyakran nem megoldható gépekkel, automatizáltan, így itt kaphat szerepet egy laikus, civil szereplő. A játékos/kutató úgynevezett „gyakorló” és „kutatási” felvételeket is kap. Előbbieket szakértők már értékelték, így, ha a versenyző helyes választ ad, akkor igen magas pontszámot kap. A kutatás alatt álló, azaz szakértő által még nem értékelt felvételek díjazása ugyan csekély, de a döntés meghozatala után a játékos ugyancsak látja,

\footnotetext{
${ }^{53} \mathrm{https}: / /$ stallcatchers.com/about\#eyesonalz-1 (2019.08.23)

54 https://stallcatchers.com/about\#stall-catchers (2019.08.23)

55 https://stallcatchers.com/about\#science-1 (2019.08.23)
} 
hogy a „tömegdöntés” mi az adott időpontban. Az eddigi teljesítmények alapján 7 laikus válasz szükséges a megbízható „tömegdöntéshez”. 56

A jelenleg rendelkezésre álló adatok kutatók általi elemzése becslések szerint több évtizedbe telne, de civilek tömegének bevonásával, „crowdsourcing”-gal (Szabó, 2013) ez az időtartam évekre redukálható. Ennek hatalmas jelentősége van egy olyan betegségnél, ahol aktuálisan a kezelési „target”, a terápiával megcélzandó folyamat is homályos. Mint a ,játék” online felületéről megtudható, a részvételnek nincs korhatára, aktuálisan (2019 augusztusában) 6 és 88 év közöttiek a játékosok ${ }^{57}$, akiknek a száma már meghaladja a 20 ezer föt. A projektgazdák értékelése szerint az adatok elemzésének sebességét máris megkétszerezték a játékban résztvevők, és ebből azt az optimista következtetést vonták le, hogy ezzel akár a demencia ellen hatásos gyógyszer kifejlesztéséhez szükséges idő is megfelezhető. Így a több évtizednyi várakozás akár 15 évre csökkenhet, de amennyiben a civil csatlakozók létszáma eléri a 30 ezret, a terápia akár 2-3 éven belül rendelkezésre állhat. Ez a becslés sajnos irreális a gyógyszerfejlesztés összetett volta, a target megtalálása utáni elengedhetetlen fejlesztési lépések időigénye miatt (Kaitin, 2018).

\footnotetext{
${ }^{56}$ Regisztrált versenyzőként 2019.08.26-ig elért eredményem: 4,36 óra játék/laboridő alatt 83.287 pontot szereztem 158 tréning és 183 kutatói videó értékelése során, amely alatt összesen 26 blokkolást azonosítottam. Ezzel a teljesítménnyel a 20.430 felhasználó közül a 979. legjobb eredményt érve el. Ezen a napon a pontgyüjtésben élen álló versenyzö össz-pontszáma: 1.764.763.232.

${ }^{57}$ Saját tapasztalatom, hogy kiskorú gyermekeim is élvezettel figyelték, miközben ,játszottam”, és nálam kevesebb gátlással, gyorsabban nyilvánítottak arról véleményt, hogy az adott részleten blokkolt-e a véráramlás.
} 


\section{Melléklet II. - Gondozási rendszer típusa és életminőség összefüggése}

Egy publikálás előtt álló, társszerzőkkel ${ }^{58}$ együtt végzett kutatás eredménye is igazolja, hogy a tartós ápolásra (long term care) fordított állami kiadás és a SHARE (Survey of Health, Ageing and Retirement in Europe) vizsgálat (Börsch-Supan és Jürges, 2005) keretében a CASP eszközzel (Higgs et al., 2003; von dem Knesebeck et al., 2005, 2007) felmért életminőség értékek között összefüggés van.

Az egy főre eső tartós ápolási kiadás és az életminőség összefüggésének vizsgálatakor három csoport rajzolódott ki. Ez a hármas tagolódás némiképp eltér a korábban más szerzők által felvázolt négyes (Nies et al., 2013; Ilinca et al., 2015), illetve kettes felosztástól (Lamura et al., 2008), de azoknak nem mond ellent. Az eltérést az úgynevezett - a korábbi elemzésekben Magyarországot is magába foglaló - közép-kelet európai (Central-Eastern Europe) és - a dél-európai országokra jellemző - családon alapuló (family-based) ellátási rendszer egybeesése, közös csoport kialakulása adja. Ezektől élesen elkülönülnek az észak-nyugati, magasabb jövedelmü országok, ahol univerzális (north universal) vagy vegyes (standard care-mix) ellátás a jellemző. Előbbit a formális ellátás magas szintje különíti el, melynél az informális ellátás kis vagy közepes szerephez jut, szemben a vegyes ellátással, ahol az informális ellátásnak valamivel nagyobb szerepet szánnak (Ilinca et al., 2015). Az időskorú lakosság életminősége és a tartós ápolás rendszere közötti összefüggés feltárását célzó kutatásunk eredményeként minimalizáló. optimalizáló vagy maximalizáló módon működő rendszereket azonosítottunk, és az alapján neveztük el a rendszereket, hogy azokba milyen mértékü invesztíció történik. Magyarország és a többi, a korábbi besorolások szerint a „családon alapuló” (family-based) vagy „közép-kelet-európai” (Central-Eastern European) rendszerekkel jellemzett országok az időskorúak életminőségének felmérése alapján a „minimalizáló” csoportba kerültek. "Optimalizáló” elnevezéssel a vegyes ellátási rendszert illettük, míg „maximalizáló” rendszernek tekintjük a formális ellátást legmagasabb szinten, legtöbb befektetéssel biztosító univerzális rendszereket.

\footnotetext{
${ }^{58}$ Patyán László, Hüse Lajos, Huszti Éva, Takács Péter - mind Debreceni Egyetem, Egészségügyi Kar
} 


\section{Hivatkozások jegyzéke}

Alves, S., Teixeira, L., Azevedo, M. J., Duarte, M., Paul, C. (2016). Effectiveness of a psychoeducational programme for informal caregivers of older adults. Scandinavian Journal of Caring Sciences, 30(1), 65-73.

Alzheimer's Disease International (2010). World Alzheimer Report 2010: The Global Economic Impact of Dementia. ADI. Elérhetö:

https://www.alz.co.uk/research/files/WorldAlzheimerReport2010.pdf (Letöltve: 2019. 02. 22.)

Alzheimer's Disease International (2015). World Alzheimer Report 2015: The Global Impact of Dementia: An analysis of prevalence, incidence, cost and trends. ADI. Elérhető: http://www.alz.co.uk/research/world-report-2015 (Letöltve: 2019. 02. 22.)

Bódy, Zs. (2017). A Népességtudományi Kutatóintézet története és a népesedéspolitika a Kádár-rendszerben. Demográfia, 59(4), 265-300.

Boyer, R.H.W., Peterson, N.D., Arora, P., Caldwell, K. (2016) Five Approaches to Social Sustainability and an Integrated Way Forward. Sustainability, 8(878), 1-18.

Börsch-Supan, A. és Jürges, H. (szerk.) 2005. The Survey of Health, Aging, and Retirement in Europe - Methodology. Mannheim Research Institute for the Economics of Aging, Mannheim.

Charlesworth, G., Sinclair, J.B., Brooks, A., Sullivan, T., Ahmad, S., Poland, F. (2017). The impact of volunteering on the volunteer: Findings from a peer support programme for family carers of people with dementia. Health \& Social Care in the Community, 25(2), 548-58.

Cowling, R.M., Egoh, B., Knight, A.T., O'Farrell, P.J., Reyers, B., Rouget, M., ... és Wilhelm-Rechman, A. (2008). An operational model for mainstreaming ecosystem services for implementation. Proceedings of the National Academy of Sciences, 105(28), 9483-8.

Dempsey, N., Bramley, G., Power, S., Brown, C. (2011). The social dimension of sustainable development: Defining urban social sustainability. Sustainable Development, 19(5), 289-300. 
Diener, E. (1984). Subjective well-being. Psychological bulletin, 95(3), 542-75.

Diener, E. és Seligman, M.E. (2004). Beyond Money: Toward an Economy of Wellbeing. Psychological Science in the Public Interest, 5(1), 1-31.

Fekete, M. (2018). Fenntartható társadalom. In Feith, H.J. (szerk.) Társadalom, család, egészség: Családtudományi alapismeretek. Budapest, Semmelweis Egyetem Egészségtudományi Kar, 268-304.

Fekete, M. (2017). Rendszertérképezés alkalmazása a hazai demenciastratégia megalapozásához. Vezetéstudomány, 48 (12), 24-32.

Fekete, M., Szabo, A., Stephens, C., Alpass, F. (2019a). Older New Zealanders in caregiving roles: Psychological functioning of caregivers of people living with dementia. Dementia, 18(5), 1663-78.

Fekete, M. (2019b). Demencia és társadalmi fenntarthatóság. Esély, 30 (2), 31-53.

Frey, B.S. és Stutzer, A. (2002). What can economists learn from happiness research? Journal of Economic literature, 40(2), 402-35.

Gébert, J. (2015). Mit is kell fenntartani? Fenntarthatóság a képességszemlélet perspektívájából. Közgazdasági Szemle, 62, 972-89.

Gitlin, L.N., Belle, S.H., Burgio, L.D., Czaja, S.J., Mahoney, D., Gallagher-Thompson, D., ... Ory, M.G. (2003). Effect of multicomponent interventions on caregiver burden and depression: the REACH multisite initiative at 6-month follow-up. Psychology and Aging, 18(3), 361-74.

Greenwood, N. és Habibi, R. (2014). Carer mentoring: A mixed methods investigation of a carer mentoring service. International Journal of Nursing Studies, 51(3), 359-69.

Griessler, E. és Littig, B. (2005). Social sustainability: a catchword between political pragmatism and social theory. International Journal for Sustainable Development, $8(1 / 2), 65-79$.

Gulácsi, L., Boncz, I., Baki, P., Péntek, M. (2012). Költségszámítás. In Gulácsi, L. (szerk.) Egészség-gazdaságtan és technológiaelemzés. Medicina, Budapest. 135-90.

Heaton, J. (1999). The gaze and visibility of the carer: a Foucauldian analysis of the discourse of informal care. Sociology of Health \& Illness, 21(6), 759-77. 
Higgs, P., Hyde, M., Wiggins, R., Blane, D. (2003). Researching Quality of Life in Early Old Age: The Importance of the Sociological Dimension. Social Policy \& Administration, 37(3), 239-52.

Hugo, J. és Ganguli, M. (2014). Dementia and cognitive impairment: epidemiology, diagnosis, and treatment. Clinics in Geriatric Medicine, 30(3), 421-42.

Hyde, M., Wiggins, R.D., Higgs, P., Blane, D.B. (2003). A measure of quality of life in early old age: the theory, development and properties of a needs satisfaction model (CASP-19). Aging \& Mental Health, 7(3), 186-94.

Ilinca, S., Leichsenring, K., Rodrigues, R. (2015). From care in homes to care at home: European experiences with (de)institutionalisation in long-term care. Policy Brief 12/2015. Vienna: European Centre.

Inglehart, R., Basanez, M., Diez-Medrano, J., Halman, L., Luijkx, R. (2004). Human beliefs and values: A cross-cultural sourcebook based on the 1999-2002 values surveys. Mexico City, Mexico: Siglo XXI.

Jackson, N. (2007). Population ageing in a nutshell: a phenomenon in four dimensions. People and Place, 15(2), 12-21.

Kahneman, D. és Krueger, A.B. (2006). Developments in the measurement of subjective well-being. Journal of Economic perspectives, 20(1), 3-24.

Kaitin, K.I. (2010). Deconstructing the drug development process: the new face of innovation. Clinical Pharmacology \& Therapeutics, 87(3), 356-61.

Kálmán, J., Kálmán, S., Pákáski, M. (2008). Demenciákhoz társuló viselkedési és pszichés zavarok felismerése és kezelése antipszichotikumokkal: A CATIE-ad vizsgálat tanulságai. Neuropsychopharmacologia Hungarica, 10(4), 233-49.

Kerekes, S. A környezetgazdaságtan alapjai: Fenntartható fejlődés, természeti erőforrásgazdálkodás, gazdasági eszközök. Aula Kiadó, Budapest, 2009. ISSN 17884713

Király, G., Köves, A., Pataki, Gy., Kiss, G. (2016). Assessing the Participatory Potential of Systems Mapping. Systems Research and Behavioral Science, 33(4), 496-514. 
Kohout, F.J., Berkman, L.F., Evans, D.A., Cornoni-Huntley, J. (1993). Two shorter forms of the CES-D (Center for Epidemiological Studies Depression) depression symptoms index. Journal of Aging and Health, 5(2), 179-93.

Krol, M., Papenburg, J., van Exel, J. (2015). Does Including Informal Care in Economic Evaluations Matter? A Systematic Review of Inclusion and Impact of Informal Care in Cost-Effectiveness Studies. PharmacoEconomics, 33(2), 123-35.

KSH (2018). A fenntartható fejlődési célok és az Agenda 2030 keretrendszer. 2018. június. www.ksh.hu/sdg (Letöltve: 2018.10.15.)

Lamura, G., Mnich, E., Nolan, M., Wojszel, B., Krevers, B., Mestheneos, L., Döhner, H. (2008). Family carers' experiences using support services in Europe: empirical evidence from the EUROFAMCARE study. The Gerontologist, 48(6), 752-71.

Leischow, S. és Milstein, B. (2006): Systems Thinking and Modeling for Public Health Practice. American Journal of Public Health, 96(3), 403-5.

Lloyd, J., Patterson, T., Muers, J. (2016). The positive aspects of caregiving in dementia: A critical review of the qualitative literature. Dementia, 15(6), 1534-61. McKenzie, S. (2004). Social Sustainability: Towards Some Definitions. Hawke Research Institute Working Paper Series, No 27.

Meadows, D.H., Meadows, D.I., Randers, J., Behrens, W.W. (1972). The Limits to Growth. (Online elérhetőség: http://www.clubofrome.org/report/the-limits-to-growth/ Letöltve 2018.08.03.)

Milne, M.J. és Gray, R. (2013). W(h)ither ecology? The triple bottom line, the global reporting initiative, and corporate sustainability reporting. Journal of Business Ethics, $118(1), 13-29$.

Murphy, K. (2012). The social pillar of sustainable development: a literature review and framework for policy analysis. Sustainability: Science, Practice and Policy, 8(1), 15-29.

Nemeroff, C.B., Weinberger, D., Rutter, M., MacMillan, H.L., Bryant, R.A., Wessely, S., ... Malhi, G.S. (2013). DSM-5: a collection of psychiatrist views on the changes, controversies, and future directions. BMC Medicine, 11(202), 1-19. 
Nies, H., Leichsenring, K., Mak, S. (2013). The Emerging Identity of Long-Term Care in Europe. In Leichsenring, K., Billings, J., Nies, H. (eds.), Long-term Care in Europe Improving Policy and Practice. Palgrave Macmillan, Basingstoke, 19-41.

OECD (2011). Compendium of OECD Well-Being Indicators. OECD

Pataki, Gy. (1998). A fejlődés gazdaságtana és etikája - Tiszteletadás Amartya Sen munkásságának. Kovász, 2(4), 6-17.

Pearlin, L.I., Mullan, J.T., Semple, S.J., Skaff, M.M. (1990). Caregiving and the stress process - An overview of concepts and their measures. Gerontologist, 30(5), 583-94.

Penke, B., Hortobágyi, T., Fülöp, L. (2016). Az öregedés és az Alzheimer-kór. MAGYAR TUDOMÁNY, 177, 573-83.

Perera, G., Pedersen, L., Ansel, D., Alexander, M., Arrighi, H.M., Avillach, P., ... Mayer, M.A. (2018). Dementia prevalence and incidence in a federation of European Electronic Health Record databases: the European Medical Informatics Framework resource. Alzheimer's \& Dementia, 14(2), 130-9.

Persányi M. (szerk.) (1988) Közös Jövőnk: A Környezet és Fejlesztés Világbizottság jelentése. Mezőgazdasági Könyvkiadó, Budapest.

Petersen, R.C., Smith, G.E., Waring, S.C., Ivnik, R.J., Tangalos, E.G., Kokmen, E. (1999). Mild cognitive impairment: clinical characterization and outcome. Archives of Neurology, 56(3), 303-8.

Petersen, R.C. (2004). Mild cognitive impairment as a diagnostic entity. Journal of Internal Medicine, 256(3), 183-94.

Pinquart, M. és Sorensen, S. (2004). Associations of caregiver stressors and uplifts with subjective well-being and depressive mood: A meta-analytic comparison. Aging \& Mental Health, 8(5), 438-49.

Prince, M., Bryce, R., Albanese, E., Wimo, A., Ribeiro, W., Ferri, C.P. (2013). The global prevalence of dementia: a systematic review and metaanalysis. Alzheimer's \& Dementia, 9(1), 63-75. 
Raymond, C. M., Fazey, I., Reed, M. S., Stringer, L. C., Robinson, G. M., Evely, A. C. (2010). Integrating local and scientific knowledge for environmental management. Journal of Environmental Management, 91(8), 1766-77.

Rozario, P.A., Morrow-Howell, N., Hinterlong, J.E. (2004). Role Enhancement or Role Strain - Assessing the Impact of Multiple Productive Roles on Older Caregiver WellBeing. Research On Aging, 26(4), 413-28.

Ryan, R.M. és Deci, E.L. (2001). On happiness and human potentials: A review of research on hedonic and eudaimonic well-being. Annual Review of Psychology, 52(1), 141-66.

Sachs-Ericsson, N. és Blazer, D.G. (2015). The new DSM-5 diagnosis of mild neurocognitive disorder and its relation to research in mild cognitive impairment. Aging \& mental health, 19(1), 2-12.

Seligman, M. és Csikszentmihalyi, M. (2000). Positive psychology - An introduction. American Psychologist, 55 (1), 5-14.

Sen, A. (1999). A relatív szegény. Esély, 2-3, 3-16.

Seyfang, G. és Smith, A. (2007). Grassroots innovations for sustainable development: Towards a new research and policy agenda. Environmental Politics, 16(4), 584-603.

Stiglitz, J.E., Sen, A., Fitoussi, J.P. (2010). Report by the commission on the measurement of economic performance and social progress. (Online elérhető: http://ec.europa.eu/eurostat/documents/118025/118123/Fitoussi+Commission+report Letöltve: 2018.08.05.)

Stiglitz, J.E., Sen, A., Fitoussi, J.P. (2010). A Bizottság jelentése a gazdasági teljesítmény és a társadalmi fejlődés méréséről. Statisztikai Szemle, 88(3), 305-20.

Szabó, K. (2013). A tudásmonopólium eróziója: a civil tudomány. Educatio, 22(3), 32336.

Tárkányi, Á. (1998.) Európai családpolitikák: a magyar családpolitika története. Demográfia, 41(2-3), 233-68.

Theodori, G.L. (2001). Examining the effects of community satisfaction and attachment on individual well-being. Rural Sociology, 66(4), 618-28. 
United Nations (2015). Transforming our world: the 2030 Agenda for Sustainable Development. Elérhető: https://documents-ddsny.un.org/doc/UNDOC/GEN/N15/291/89/PDF/N1529189.pdf?OpenElement (Letöltve: 2019.03.31.)

Van den Berg, B., Brouwer, W.B., Koopmanschap, M.A. (2004). Economic valuation of informal care. The European Journal of Health Economics, formerly: HEPAC, 5(1), $36-45$.

Vanhoutte, B. (2012). Measuring subjective well-being in later life: A review. Manchester: University of Manchester. 1-53.

Volosin, M., Janacsek, K., Németh, D. (2013). A Montreal Kognitív Felmérés (MoCa) magyar nyelvü adaptálása egészséges, enyhe kognitív zavarban és demenciában szenvedő idős személyek körében. Psychiatria Hungarica, 28(4), 370-92.

von dem Knesebeck, O., Hyde, M., Higgs, P., Kupfer, A., Siegrist, J. (2005). Quality of Life and Well-Being. In Börsch-Supan, A., Brugiavini, A., Jürges, H., Kapteyn, A., Mackenbach, J., Siegrist, J., Weber, G. (szerk.) Health, Ageing and Retirement in Europe - First Results from the Survey of Health, Ageing and Retirement in Europe. Mannheim Research Institute for the Economics of Aging, Mannheim, 199-203.

von dem Knesebeck, O., Wahrendorf, M., Hyde, M., Siegrist, J. (2007). Socioeconomic position and quality of life among older people in 10 European countries: Results of the SHARE study. Ageing \& Society, 27(2), 269-84.

Ware, J.E., Kosinski, M., Keller, S.D., Lincoln, R.I. (1998). SF-12: How to score the SF-12 physical and mental health summary scales. Quality Metric incorporated. Boston MA.

WCED (1987). Report of the World Commission on Environment and Development: Our Common Future. World Commission on Environment and Development, General Assembly as an Annex to document A/42/427. Development and International Cooperation: Environment (Elérhető: http://www.un-documents.net/wced-ocf.htm Letöltve: 2018.08.01.) 
Wennberg, A., Dye, C., Streetman-Loy, B., Pham, H. (2015). Alzheimer's patient familial caregivers: a review of burden and interventions. Health \& Social Work, 40(4), $162-9$.

Wiggins, R.D., Netuveli, G., Hyde, M., Higgs, P., Blane, D. (2008). The evaluation of a selfenumerated scale of quality of life (CASP-19) in the context of research on ageing: A combination of exploratory and confirmatory approaches. Social Indicators Research, 89(1), 61-77.

Wiseman, J. és Brasher, K. (2008). Community wellbeing in an unwell world: Trends, challenges, and possibilities. Journal of Public Health Policy, 29(3), 353-66.

World Bank Group (2016). Global Monitoring Report 2015/2016: Development Goals in an Era of Demographic Change. Washington, DC: World Bank. DOI: 10.1596/978-14648-0669-8. License: Creative Commons Attribution CC BY 3.0 IGO (Elérhető: http://pubdocs.worldbank.org/en/503001444058224597/Global-Monitoring-Report2015.pdf Letöltve: 2019.09.12)

World Health Organization (2008). Mental Health Global Action Programme - Scaling up care for mental, neurological, and substance use disorders. World Health Organization. ISBN 9789241596206

World Health Organization (2018). Towards a dementia plan: a WHO guide. WHO.

Wortmann, M. (2012). Dementia: a global health priority-highlights from an ADI and World Health Organization report. Alzheimer's Research \& Therapy, 4(40), 1-3.

Zarit, S.H., Stephens, M.A.P., Townsend, A., Greene, R. (1998). Stress reduction for family caregivers: Effects of adult day care use. The Journals of Gerontology Series B: Psychological Sciences and Social Sciences, 53(5), 267-77. 


\section{Köszönetnyilvánítás}

Az elmúlt közel 6 évért számos embernek köszönettel tartozom. Azoknak is, akik mindig bíztattak, és végeredményben azoknak is, akik nem, mert minden hatás afelé lökött valamilyen módon, hogy amibe belekezdtem, azt ezúttal is fejezzem be.

Szeretek tanulni, de talán soha nem élveztem ennyire, hogy új ismereteket és készségeket szerzek. Több szempontból nagyon meghatározó élmény volt számomra a képzés első éve, amelynek során a kutatásmódszertani alapokat sajátítottuk el. Mindig is szerettem a matematikát, és Szüle Borbála órái alatt sajnáltam igazán, hogy azt soha nem „az igazi módon" tanultam addig, hanem hagytam, hogy a túl korai - később valamelyest tévútnak bizonyult - pályaválasztás által meghatározott út attól egyfajta tiszteletteljes távolságban tartson. Bori türelme, segítőkészsége, majd a sikereknél a bíztatása a kurzus teljesítése utáni időkben is meghatározó volt. Későbbi oktatói munkám során is példaként szolgált ahogy Bori tanított: az oktató lelkesedése, annak szeretete, amiröl beszél, biztos ösztönző hatású a hallgatóra. Ugyanez volt az érzésem Pataki György kvalitatív módszertani kurzusain is, azzal a különbséggel, hogy Gyuri egy olyan világba vezetett be, aminek tulajdonképpen addig a létezéséről sem tudtam. A kvalitatív kutatási módszertan megismerése komoly hatással volt kutatóvá válásomra is, mondhatni megfertőződtem. Az addig a számok büvöletében élő énem ráébredt, hogy a számok mögé kell nézni, pláne azon a területen, ahova a kutatási fókuszom kanyarodott. Gyuri nem csak az elmélet megismerésében segített, hanem amikor elhatároztam, hogy életem első kutatásának melyből publikáció is született - nekiállok, akkor sok gyakorlati segítséget is kaptam tőle. A kvalitatív kutatási módszerek iránti elköteleződésem nem bizonyult múló hóbortnak: megpróbáltam Gyuri nyomdokaiba lépni, és oktatói tevékenységem során én is igyekeztem a hallgatókat efelé az elsőre idegen, ugyanakkor számomra az igazi kutatói kiteljesedést jelentő módszertan felé terelni. Pataki György 2017 óta a témavezetőm, akkortól, amikor világossá vált, hogy a terület, amelyben elmélyedve kutatóvá szerettem volna válni, tulajdonképpen egy fenntarthatósági téma. Ezzel az aspektussal egy újabb ajtó nyílt meg előttem, és tagadhatatlanul azóta a gondolkodásomra és a mindennapi életemre is hatással van ez a szemlélet. 
Bár számos oktatómat szívesen említeném meg név szerint, de még Juhász Péternek szeretném külön megköszönni a rendkívül élvezetes és tartalmas kommunikációfejlesztés kurzus óráit, melyből a mai napig építkezem és adok tovább kincseket.

A demenciára szakmai életutam egy rövid kitérője irányította a figyelmemet, emiatt nagyon jó döntésnek bizonyult, hogy a PhD képzésbe egy év halasztással léptem be. A demencia gyógymódját kereső fejlesztőrészleg munkájában történő rövid, de intenzív részvétel alatt rengeteget tanultam a kórképről, de magáról a gyógyszerfejlesztés folyamatáról is. Első témavezetőmnek, Gulácsi Lászlónak köszönhetem az első kapcsolatot egy olyan szervezettel, akik a demencia társadalmi kérdésével és a szociális ellátórendszer szerepével foglalkoznak. Ezután hol szerencsés véletlenek, hol célzott kapcsolatfelvételek útján bővült az a kapcsolati háló körülöttem, amelynek minden egyes tagját valamiért köszönet illetné. Voltak, akik a hozzátartozókat támogató csoportok világába vezettek be, ezeken keresztül sok gondozó családtagot ismertem meg, akik közül sokan hajlandóak voltak velem megosztani legnagyobb fájdalmaikat és apró örömeiket. Talán mivel a probléma társadalmi megközelítésével kevesen foglalkoznak hazánkban, sokszor éreztették velem, hogy fontos, amit csinálok. Közvetlen és közvetett módon rengeteg támogatást kaptam számos „harcostárstól”, akikkel együtt próbálunk azért küzdeni, hogy a demencia ügye kellö mértékü figyelmet kapjon a szakpolitikától és a társadalomtól is. Szociális- és egészségügyi szakterületek, valamint gondozó hozzátartozók példaértékủ együttmüködése valósul meg számos elkötelezett közösségben, és hálás vagyok azért, hogy sokakat megismerhettem.

Köszönettel tartozom az új-zélandi Massey University-n Christine Stephens professzor asszonynak, aki az egyetemen müködő Health and Ageing Research Team egyik vezetője, és lehetővé tette, hogy a kutatócsoport által gyüjtött adatbankot forrásul használhassam. Itt ismertem meg Szabó Ágnest, akinek segítsége nélkül nem született volna meg eddigi legnagyobb szakmai sikerem, az angol nyelvü publikációm. Ági mentorként vezetett végig az úton a kutatási kérdések megfogalmazásától a publikáció megszületéséig, melyben hatalmas részt vállalt a statisztikai elemzési munkájával és a publikáció végső formába öntésével. És akinek a segítsége nélkül szintén nem jutottam volna el addig, hogy ezt az írást most valaki olvassa, Julie Doyle, aki Új-Zélandon nyelvi fejlesztésem legkedvesebb mestere volt, és akit azóta barátomnak tudhatok. Julie állandó érdeklődést mutatott munkám iránt, és vállalta a disszertáció főszövegének angol nyelvü lektorálását. 
Végül, de elsősorban családomnak köszönöm meg, hogy élhettem hobbimnak, a tanulásnak, bár ez az elmúlt 6 év végül többnek bizonyult, mint egy tanulási folyamat. Köszönöm férjemnek, hogy mindig biztatott, teret és időt biztosított az úton való haladáshoz. És bár ez még nem az ő PhD disszertációjának a köszönetnyilvánítása, de valójában ő is köszönettel tartozik a kvantitatív módszertani ismereteim bővüléséért, mivel az ő tudományos tevékenysége is gyakorlóterepül szolgált számomra - ezzel legalább kárpótoltam. Köszönöm az évek alatt kicsiböl nagylánnyá cseperedő gyermekeimnek, hogy megbocsátóak, és elfogadták, hogy nekem a tanulás éppúgy része az életemnek, mint nekik. Ebben szüleim is segítségemre voltak, akiknek az otthona lányaimnak mindig maga a kánaán volt, így néha talán nem is bánták, ha én egy egész hétvégére, vagy éppen 88 napra elvonultam, hogy a tudománynak élhessek. Köszönet illeti férjem szüleit is, akik szintén mindig biztosítottak támogatásukról, és a haladásom iránti érdeklődésük bizonyítéka volt annak, hogy őszintén értékelik munkámat.

És végül emlékeztetőül a mottóm, melyet nem csak a disszertáció kedvéért választottam:

„Az emberek azért kezdenek kutatásba, mert van egy álmuk arról, hogy belátásaikkal és felismeréseikkel hozzátesznek valami fontosat a világhoz. Azonban nem elég csupán álmodozni, álmainkat meg is kell tudnunk valósítani. " /Juliet Corbin - Anselm Strauss, 2015 - A kvalitatív kutatás alapjai; L'Harmattan - SE-EKK - SAGE, elsö magyar kiadás, 54.o./

Úgy érzem, megvalósítottam! Köszönöm, hogy megvalósíthattam! 